\title{
online Appendix \\ The Elephant in the Room: the Impact of Labor Obligations on Credit Markets
}

\author{
By JaCk Favilukis, Xiaoji Lin and Xiaofei Zhao
}

The BALANCED Growth PATH AND DETRENDING THE MODEL

Note that the model is not stationary, because $Z_{t}$ is not stationary. In order to solve it numerically, we must rewrite it in terms of stationary quantities. The balanced growth path of a frictionless version of this model follows $Z_{t}^{\rho}$. If a balanced growth path of the model with frictions exists, and if this problem, detrended by some quantity, has a stationary solution, then that quantity must also be $Z_{t}^{\rho}{ }^{1}$ To see this, define $k_{t}^{i}=\frac{K_{t}^{i}}{Z_{t}^{\rho}}$ and plug it into the production function: (A1)

$Y_{t}^{i}=Z_{t}^{i}\left(\alpha\left(K_{t}^{i}\right)^{\eta}+(1-\alpha)\left(Z_{t} N_{t}^{i}\right)^{\eta \rho}\right)^{\frac{1}{\eta}}=Z_{t}^{i}\left(\alpha\left(k_{t}^{i}\right)^{\eta}+(1-\alpha)\left(N_{t}^{i}\right)^{\eta \rho}\right)^{\frac{1}{\eta}} Z_{t}^{\rho}=y_{t}^{i} Z_{t}^{\rho}$

We will now rewrite the rest of the firm's problem in terms of detrended quantities. The firm's original problem is:

$$
\begin{aligned}
& V\left(Z_{t}^{i}, K_{t}^{i}, N_{t-1}^{i}, \bar{W}_{t-1}^{i}, \kappa_{t}^{i} ; Z_{t}, x_{t}, \widehat{K}_{t}, \bar{W}_{t-1}\right)=\max (0 \\
& \quad \max ^{i}(1-\tau)\left(Y_{t}^{i}-\bar{W}_{t}^{i} N_{t}^{i}-\digamma_{t}-\kappa_{t}^{i}\right)+\tau \delta K_{t}^{i} \\
& \quad-I_{t}^{i}, \kappa_{t+1}^{i}-\Phi\left(K_{t}^{i}, I_{t}^{i}\right)+\Psi_{t}^{i} 1_{\{I s s u e\}} \\
& \left.\quad+E_{t}\left[M_{t+1} V\left(Z_{t+1}^{i}, K_{t+1}^{i}, N_{t}^{i}, \bar{W}_{t}^{i}, \kappa_{t+1}^{i} ; Z_{t+1}, x_{t+1}, \widehat{K}_{t+1}, \bar{W}_{t}\right)\right]\right),
\end{aligned}
$$

where $Z_{t}^{i}$ is the idiosyncratic productivity, $K_{t}^{i}$ is the firm's individual capital, $N_{t-1}^{i}$ is the firm's employment last period, $\kappa_{t}^{i}$ is the current coupon payment paid, $\Psi_{t}^{i}$ are the proceeds from issuing new debt, $\bar{W}_{t-1}^{i}$ is the firm's average wage last period, $Z_{t}$ is aggregate productivity, $x_{t}$ is the conditional mean of aggregate productivity growth, $\bar{W}_{t-1}$ is the aggregate average wage from last period, and $W_{t}$ is the spot wage this period. ${ }^{2}$ Following (Krusell and Smith 1998) the state space potentially contains all information about the joint distribution of capital and productivity. $\widehat{K}_{t}$ is a vector of aggregate state variables which summarize the distribution of capital, it includes the first moment or average level of capital $K_{t}$,

\footnotetext{
${ }^{1}$ No other quantity $X$ allows $\frac{Y}{X}=f\left(\frac{K}{X}\right)$ where $\mathrm{f}($. $)$ is not a function of $Z$.

${ }^{2}$ Note that we changed the notation slightly from the main text. Here, wage related variables are written as capital letters, so that we can write the detrended variable as lower case.
} 
but may include higher moments, as suggested by (Krusell and Smith 1998).

Households have beliefs about the spot wage $W_{t}$, aggregate output $Y_{t}$, and aggregate consumption $C_{t}$ as a function of the aggregate state, about the evolution of the aggregate quantities $M_{t+1}$ and $\widehat{K}_{t}$, and about the price of debt $\Psi_{t}^{i}$. The price of debt is a function of the aggregate state at $t$, the firm's productivity at $t$, and the choices firm makes at $t$ that impact its state at $t+1 .^{3}$ The aggregate wage and average capital evolve as

$$
\begin{aligned}
& \bar{W}_{t}=\mu \bar{W}_{t-1}+(1-\mu) W_{t} \\
& K_{t+1}=(1-\delta) K_{t}+I_{t}
\end{aligned}
$$

The evolution of the individual state variables depend on the firm's choices: ${ }^{4}$

$$
\begin{aligned}
& K_{t+1}^{i}=(1-\delta) K_{t}^{i}+I_{t}^{i} \\
& \bar{W}_{t}^{i}=\frac{\bar{W}_{t-1}^{i} N_{t-1}^{i} \mu+\left(N_{t}^{i}-N_{t-1}^{i} \mu\right) W_{t}}{N_{t}^{i}}
\end{aligned}
$$

We can define $k_{t}=\frac{K_{t}}{Z_{t}^{\rho}}, \widehat{k}_{t}=\frac{\widehat{K}_{t}}{Z_{t}^{\rho}}, i_{t}^{i}=\frac{I_{t}^{i}}{Z_{t}^{\rho}}, \varrho_{t}^{i}=\frac{\Psi_{t}^{i}}{Z_{t}^{\rho}}, \widetilde{\kappa}_{t}^{i}=\frac{\kappa_{t}^{i}}{Z_{t}^{\rho}}, w_{t}=\frac{W_{t}}{Z_{t}^{\rho}}$, $\bar{w}_{t}^{i}=\frac{\bar{W}_{t}^{i}}{Z_{t+1}^{\rho}}$, and $\bar{w}_{t}=\frac{\bar{W}_{t}}{Z_{t+1}^{\rho}}$ (note that the timing of $\bar{w}_{t}^{i}$ and $\bar{w}_{t}$ differs from the others).

With this normalization, it can be shown by induction that the value function is linear in $Z_{t}^{\rho}$. Suppose this is true at $\mathrm{t}+1$ :

$V\left(Z_{t+1}^{i}, K_{t+1}^{i}, N_{t}^{i}, \bar{W}_{t}^{i}, \kappa_{t}^{i} ; Z_{t+1}, x_{t+1}, \widehat{K}_{t+1}, \bar{W}_{t}\right)=Z_{t+1}^{\rho} v\left(Z_{t+1}^{i}, k_{t+1}^{i}, N_{t}^{i}, \bar{w}_{t}^{i}, \widetilde{\kappa}_{t+1}^{i} ; 1, x_{t+1}, \widehat{k}_{t+1}, \bar{w}_{t}\right)$

Then we can rewrite the firm's problem as: ${ }^{5}$

$$
\begin{aligned}
& v\left(Z_{t}^{i}, k_{t}^{i}, N_{t-1}^{i}, \bar{w}_{t-1}^{i}, \widetilde{\kappa}_{t}^{i} ; x_{t}, \widehat{k}_{t}, \bar{w}_{t-1}\right)=\max (0 \\
& \quad \max _{i_{t}^{i}, N_{t}^{i} \widetilde{\kappa}_{t+1}^{i}(1-\tau)\left(y_{t}^{i}-\bar{w}_{t}^{i} N_{t}^{i}-\digamma_{t}-\widetilde{\kappa}_{t}^{i}\right)+\tau \delta K_{t}^{i}} \quad-i_{t}^{i}-\Phi\left(k_{t}^{i}, i_{t}^{i}\right)+\varrho_{t}^{i} 1_{\{I s s u e\}} \\
& \left.\quad+E_{t}\left[\left(\frac{Z_{t+1}}{Z_{t}}\right)^{\rho} M_{t+1} v\left(Z_{t+1}^{i}, k_{t+1}^{i}, N_{t}^{i}, \bar{w}_{t}^{i}, \widetilde{\kappa}_{t+1}^{i} ; x_{t+1}, \widehat{k}, \bar{w}_{t}\right)\right]\right)
\end{aligned}
$$

\footnotetext{
${ }^{3}$ In particular, beliefs at $t$ about the firm's future repayment ability depend on $\kappa_{t}^{i}, K_{t+1}^{i}, \bar{W}_{t}^{i}$, and $N_{t}^{i}$ which are all functions of choices the firm makes at $t$. This will be explained in more detail in the next section.

${ }^{4}$ Note that past employment $N_{t-1}^{i}$ is also part of the state; we are not including its evolution in this equation because its choice at $t$ is exactly equal to its value at $t+1$.

${ }^{5}$ For notational convenience, we have suppressed the value function's dependence on the level of productivity (first argument of the aggregate state) because in the detrended value function, that argument is always equal to one.
} 
where the aggregate capital and wage evolve as

$$
\begin{aligned}
& k_{t+1}=\left((1-\delta) k_{t}+i_{t}\right)\left(\frac{Z_{t+1}}{Z_{t}}\right)^{-\rho} \\
& \bar{w}_{t}=\left(\mu \bar{w}_{t-1}+(1-\mu) w_{t}\right)\left(\frac{Z_{t+1}}{Z_{t}}\right)^{-\rho}
\end{aligned}
$$

and the individual state variables evolve as:

$$
\begin{aligned}
& k_{t+1}^{i}=\left((1-\delta) k_{t}^{i}+i_{t}^{i}\right)\left(\frac{Z_{t+1}}{Z_{t}}\right)^{-\rho} \\
& \bar{w}_{t}^{i}=\left(\frac{\bar{w}_{t-1}^{i} N_{t-1}^{i} \mu+\left(N_{t}^{i}-N_{t-1}^{i} \mu\right) w_{t}}{N_{t}^{i}}\right)\left(\frac{Z_{t+1}}{Z_{t}}\right)^{-\rho} \\
& \widehat{\kappa}_{t+1}^{i}= \begin{cases}0 & \text { if expiry or default at } t+1 \\
\widehat{\kappa}_{t}^{i}\left(\frac{Z_{t+1}}{Z_{t}}\right)^{-\rho} & \text { otherwise }\end{cases}
\end{aligned}
$$

As long as the firm believes that $\left(\frac{Z_{t+1}}{Z_{t}}\right)^{\rho}, M_{t+1}, k_{t+1}, w_{t+1}$, and $\varrho_{t}^{i}$ are stationary (by stationary, we mean that they do not depend on the level of aggregate productivity $Z_{t}$ ), then this is a well defined problem, similar to many standard problems in finance and economics. Whether it has a finite solution depends on the parameters (for example, if $M_{t+1}=\beta>1$ then it likely does not have a finite solution), however this is a problem that can be solved numerically by dynamic programming if a finite solution exists. If a finite solution exists, then the firm's optimal policy $\left(i_{t}^{i}, N_{t}^{i}, \widetilde{\kappa}_{t}^{i}\right)$ will also be stationary.

Note that if a finite solution to this problem exists, then all endogenous firm level variables will be stationary when detrended by $Z_{t}^{\rho}$. A stationary individual capital $k_{t}^{i}$ implies that the aggregate detrended capital stock $k_{t+1}=\sum k_{t+1}^{i}$ and aggregate investment are stationary too. A stationary labor demand $N_{t}^{i}$ implies that the aggregate labor demand $N_{t}=\sum N_{t}^{i}$ is stationary too. In equilibrium, the aggregate labor demand is equal to the aggregate labor supply, which is one, but since the aggregate labor demand is a simple function of the detrended spot wage, inverting the relationship implies a stationary detrended spot wage as well. A stationary detrended output puts an upper bound on coupon payments, which implies a stationary price of debt.

Thus, if the firm believes that the detrended capital, average wage, spot wage, and bond price are stationary, and if the firm's detrended problem given these beliefs has a finite solution, then indeed these quantities must be stationary.

Finally, we can rewrite the stochastic discount factor and bond price in terms of stationary quantities. The original utility function and stochastic discount factor 
were defined as:

$$
\begin{aligned}
& C_{t}=Y_{t}-I_{t} \\
& U_{t}=\left(C_{t}^{1-\frac{1}{\psi}}+\beta E_{t}\left[U_{t+1}^{1-\theta}\right]^{\frac{1-\frac{1}{\psi}}{1-\theta}}\right)^{\frac{1}{1-\frac{1}{\psi}}} \\
& M_{t+1}=\beta\left(\frac{U_{t+1}}{E_{t}\left[U_{t+1}^{1-\theta}\right]^{\frac{1}{1-\theta}}}\right)^{\frac{1}{\psi}-\theta}\left(\frac{C_{t+1}}{C_{t}}\right)^{-\frac{1}{\psi}}
\end{aligned}
$$

Define $c_{t}=\frac{C_{t}}{Z_{t}^{\rho}}$ and $u_{t}=\frac{U_{t}}{Z_{t}^{\rho}}$ and note that the firm's optimal policy implies that $c_{t}=y_{t}-i_{t}$ is stationary. We can rewrite the above equations as:

$$
\begin{aligned}
& c_{t}=y_{t}-i_{t} \\
& u_{t}=\left(c_{t}^{1-\frac{1}{\psi}}+\beta E_{t}\left[\left(\frac{Z_{t+1}}{Z_{t}}\right)^{\rho} u_{t+1}^{1-\theta}\right]^{\frac{1-\frac{1}{\psi}}{1-\theta}}\right)^{\frac{1}{1-\frac{1}{\psi}}} \\
& M_{t+1}=\beta\left(\frac{\left(\frac{Z_{t+1}}{Z_{t}}\right)^{\rho} u_{t+1}}{E_{t}\left[\left(\frac{Z_{t+1}}{Z_{t}}\right)^{\rho} u_{t+1}^{1-\theta}\right]^{\frac{1}{1-\theta}}}\right)^{\frac{1}{\psi}-\theta}\left(\frac{c_{t+1}}{c_{t}}\right)^{-\frac{1}{\psi}}\left(\frac{Z_{t+1}}{Z_{t}}\right)^{-\frac{\rho}{\psi}}
\end{aligned}
$$

which are stationary as long as $c_{t}$ is stationary.

The original equation for the bond price is

$$
\begin{aligned}
\Psi_{t}^{i}=E_{t} M_{t+1} & {\left[1_{\{\exp \}} \times 0+\left(1-1_{\{\exp \}}\right) \times 1_{\left\{V_{t+1} \leq 0\right\}} \times V_{t+1}^{0}+\right.} \\
& \left.\left(1-1_{\{\exp \}}\right)\left(1-1_{\left\{V_{t+1} \leq 0\right\}}\right)\left(\kappa_{t+1}^{i}+\Psi_{t+1}^{i}\right)\right] .
\end{aligned}
$$

This can be rewritten as

$$
\begin{aligned}
\varrho_{t}^{i}=E_{t} M_{t+1} \quad & {\left[( \frac { Z _ { t + 1 } } { Z _ { t } } ) ^ { \rho } \left[1_{\{\exp \}} \times 0+\left(1-1_{\{\exp \}}\right) \times 1_{\left\{V_{t+1} \leq 0\right\}} \times v_{t+1}^{0}+\right.\right.} \\
& \left.\left.\left(1-1_{\{\exp \}}\right)\left(1-1_{\left\{V_{t+1} \leq 0\right\}}\right)\left(\widetilde{\kappa}_{t+1}^{i}+\varrho_{t+1}^{i}\right)\right]\right],
\end{aligned}
$$

where $v_{t+1}^{0}$ is the detrended value of a firm with zero debt.

\section{NumericAL ALGORITHM}

We will now describe the numerical algorithm used to solve the stationary problem above, which is described by equations A6, A7, A8, A10, and A12. The algorithm is a variation of the algorithm in (Krusell and Smith 1998). Generally, there is no proof that an equilibrium exists. This solution method is referred to as an approximate bounded rational equilibrium. It consists of performing two steps and then repeating them until convergence. The first (partial equilibrium) step solves the firm's problem given a particular set of beliefs; the inputs are beliefs and the outputs are policy functions. The second (general equilibrium) step updates these beliefs from simulating the economy; the inputs are policy functions and 
the outputs are beliefs. These steps are repeated until the beliefs have converged and are consistent with simulated data. We will refer to the sequence of step one, followed by step two as a single outer iteration. This is to differentiate these iterations from the value function iteration which occurs during step one.

In the previous section, for generality, we allowed the aggregate state space to include a vector of variables describing he distribution of capital across firms, $\widehat{k}_{t}$. However, in practice, we only keep track of the first moment of capital, therefore $\widehat{k}_{t}=\left\{k_{t}\right\}$. To ease notation, we summarize the aggregate state by the vector $\Theta_{t}=\left\{x_{t}, k_{t}, \bar{w}_{t-1}\right\}$, which includes expected productivity growth, average capital, and past average wage. The individual state space is summarized by the vector $\Theta_{t}^{i}=\left\{Z_{t}^{i}, k_{t}^{i}, N_{t-1}^{i}, \bar{w}_{t-1}^{i}, \widetilde{\kappa}_{t}^{i}\right\}$, which includes individual productivity, capital, past labor, past average wage, and the current coupon due.

For numerical reasons, we find it better to rescale two of the state variables. In particular instead of $\bar{w}_{t-1}^{i}$ we use $N_{t-1}^{i} \bar{w}_{t-1}^{i}$. This rescaling is innocuous because one can easily go back and forth. It can be shown that when there is no debt or adjustment costs, the firm's problem is linear in $N_{t-1}^{i} \bar{w}_{t-1}^{i}$ and $N_{t-1}^{i}$, and thus we believe the rescaling leads to a more efficient algorithm. Further, it allows us to check the accuracy of our solution in the special case of $\nu=0$. Instead of $\bar{w}_{t-1}$, we use $\bar{w}_{t-1}$ scaled by the aggregate marginal product of labor. This is done because $\bar{w}_{t-1}$ is highly correlated with $k_{t}$, which makes formation of beliefs more difficult without rescaling. Further, when two state variables are correlated, large areas of the grid are left unused, which wastes computing power. The scaling reduces this correlation. Even though we rescale the variables in our code, we write everything in terms of the original variables here, to make the exposition easier.

The grid sizes are 43 for firm capital $k_{t}^{i}, 18$ for the firm's past average wage $\bar{w}_{t-1}^{i}, 13$ for the firm's past employment $N_{t-1}^{i}, 13$ for the firm's owed coupon (which is equivalent to the firm's book value of debt) $\widehat{\kappa}_{t}^{i}, 20$ for aggregate capital $k_{t}, 6$ for the aggregate past average wage $\bar{w}_{t-1}, 3$ for the Markov chain governing the conditional expectation of aggregate productivity growth $x_{t}, 3$ for the shortrun shock to productivity growth $\epsilon$, and 3 for the Markov chain governing firm productivity $Z_{t}^{i}$. We have experimented with grid sizes extensively and set them large enough that our results are not affected by any further increases. ${ }^{6}$ It is important to set the grid edges some distance away from where typical variables reside, despite these values being "off-equilibrium." At the same time, setting the edges too far away from model equilibrium will require a very large number of grid points, which is numerically infeasible; therefore, some experimentation is in order. We find that the results are more sensitive to the sizes of firm level grids than to the aggregate grids.

\footnotetext{
${ }^{6}$ More specifically, we have solved the same problem but where all of the grids have approximately 30 percent fewer grid points (with the exception of the productivity shock grids, as we keep those shocks discrete). We have also solved the same problem but where each grid, one at a time, has approximately 50 percent more grid points (we are unable to simultaneously increase all grid points due to computing limitations). We find that the moments of interest are very similar to the ones reported in the text.
} 
The problem is solved using Fortran 77, and parallelized using OpenMP. It then runs on eight parallel processors. The full model takes about 3 hours per outer iteration and requires 50 to 100 outer iterations to converge. We are appreciative of The Ohio State University high-performance computing center for the computational resources.

Step 1. We begin this step with beliefs about aggregate output, the spot wage, and aggregate consumption as a function of the aggregate state. As will be shown below, these are sufficient to predict the aggregate state next period. There is also a belief about the stochastic discount factor as a function of the aggregate state, and the realized shock next period. These beliefs are $\sum y_{t}^{i}=\vartheta^{n}\left(\Theta_{t}\right)$, $w_{t}=\omega^{n}\left(\Theta_{t}\right), c_{t}=\zeta^{n}\left(\Theta_{t}\right)$ and $M_{t+1}=\mathbb{M}^{n}\left(\Theta_{t}, j_{t+1}\right)$, where $j_{t+1}$ is the discrete realization of the aggregate productivity shock. Here $n$ indicates the number of the outer iteration.

Additionally, there is a belief about the bond price. The bond price deserves a special explanation. The bond price at $t\left(\varrho_{t}^{i}\right)$ must depend on the aggregate state $\Theta_{t}$ since this affects beliefs about both aggregate productivity, and the stochastic discount factor; the first of which affects default probability, and the second discounting of future cash flows. It must also depend on individual productivity $Z_{t}^{i}$ since this affects beliefs about future productivity and the firm's ability to repay. Importantly, it must depend on the firm's choice of coupon payments $\widetilde{\kappa}_{t+1}^{i}$ since the level of the coupon payment affects the firm's default decision, thus, the firm receives a menu of bond prices over all possible choices of coupons.

It must also depend on the firm's other characteristics: its capital level, past average wage, and past labor. However, here we must make a modeling choice. If the firm chooses its time $t$ investment $i_{t}^{i}$ and labor $N_{t}^{i}$ after the time $t$ debt has been issued, then the price of debt should depend on $\left\{k_{t}^{i}, N_{t-1}^{i}, \bar{w}_{t-1}^{i}\right\}$. However, if the firm chooses its time $t$ investment and labor concurrently to issuing its time $t$ debt, then the price of debt will depend on the firm's choices, just like it does on its choice of coupon payments.

We choose the later approach, because we want to prevent the firm from gaming the creditors. Consider the following example. If the price of debt depended only on time $t$ capital $k_{t}^{i}$, then the firm could issue a large amount of debt, then immediately pay a large dividend, leaving it with a tiny capital stock going forward, and high likelihood of future default. Of course, creditors would anticipate this and demand very high returns. This scenario does not strike us as a realistic description of lending markets; in the real world, debt covenants typically prevent this from happening. For this reason, the price of debt is not a function of the firm's capital at $t\left(k_{t}^{i}\right)$, but rather is a function of its choice of capital for $t+1$, which is known at $t\left(k_{t}^{i}(1-\delta)+i_{t}^{i}\right)$. Similarly, it is not a function of the firm's time $t$ lagged labor $\left(N_{t-1}^{i}\right)$ and lagged average wage $\left(\bar{w}_{t-1}\right)$, but rather a function of the firm's time $t$ choice of labor $\left(N_{t}^{i}\right)$, and its average wage $\left(\frac{\bar{w}_{t-1}^{i} N_{t-1}^{i} \mu+\left(N_{t}^{i}-N_{t-1}^{i} \mu\right) w_{t}}{N_{t}^{i}}\right)$. The beliefs about the bond price are defined over the same grids over which the aggregate and individual state spaces are defined. We express the belief about 
the bond price as

$$
\varrho_{t}^{i}=\sigma^{n}\left(\Theta_{t}, Z_{t}^{i}, k_{t}^{i}(1-\delta)+i_{t}^{i}, N_{t}^{i}, \frac{\bar{w}_{t-1}^{i} N_{t-1}^{i} \mu+\left(N_{t}^{i}-N_{t-1}^{i} \mu\right) w_{t}}{N_{t}^{i}}, \widetilde{\kappa}_{t+1}^{i}\right)
$$

which depends explicitly on the firm's choices $\left\{i_{t}^{i}, N_{t}^{i}, \widetilde{\kappa}_{t+1}^{i}\right\}$.

These beliefs, together with equations A6, A7, and A8, specify a well-defined partial equilibrium firm problem. We solve this problem using value function iteration.

Once the value function iteration is complete, it produces three policy functions for the firm: investment $i^{n}\left(\Theta_{t}^{i}, \Theta_{t}\right)$, employment $N^{n}\left(\Theta_{t}^{i}, \Theta_{t}\right)$, and choice of coupon payment $\widehat{\kappa}_{t+1}^{n}\left(\Theta_{t}^{i}, \Theta_{t}\right)$. Recall that the coupon payment is a choice only for firms that are resetting their debt, all others (who defaulted or whose debt expired) have no coupon payments. The value function iteration also produces an equity value as a function of the state $v^{n}\left(\Theta_{t}^{i}, \Theta_{t}\right)$, and a default policy because the firm defaults any time the equity value is less than or equal to zero. The updating of the debt pricing function is described further below.

Step 2. In this step we use the policy functions to simulate the economy and then use simulated data to update the beliefs. We simulate the economy for 10,000 firms, and a higher number does not affect any of our results. Before beginning the simulation we must specify an initial distribution of idiosyncratic productivity, capital, past wages, and past labor. We simulate the economy for 3,500 periods and throw away the first 500 periods to let the simulation settle into its normal behavior; this also assures that the initial distribution has no effect on our results.

One complication during the simulation is that we must clear the labor market each period. The difficulty is that each firm's choice of labor at $t$ is a function of the state variables at $t$. The state variables are fixed and known at the beginning of $t$, thus labor is determined at the start of the period. The firms have beliefs about the spot wage as a function of the state; however, before convergence these beliefs may be incorrect, and, therefore, labor demand may not equal labor supply. The actual market clearing spot wage (as opposed to the belief) is undefined because at this stage in the simulation, nothing can change the state variables or firms' labor demand. To deal with this problem we use the following workaround: during the simulation, we assume that each firm's labor demand is $N_{t}^{i}=\mathbb{N}^{i}\left(Z_{t}^{i}, k_{t}^{i}, N_{t-1}^{i}, \bar{w}_{t-1}^{i} ; \Theta_{t}\right) \frac{\omega^{n}\left(\Theta_{t}\right)}{w_{t}}$, where $\mathbb{N}\left(Z_{t}^{i}, k_{t}^{i}, N_{t-1}^{i}, \bar{w}_{t-1}^{i} ; \Theta_{t}\right)$ is the policy function from step 1 , and $\omega^{n}\left(\Theta_{t}\right)$ is the belief about the spot wage used during the value function iteration step. Each period, we choose the spot wage $w_{t}$ in order to clear the labor market, that is, to ensure that $\sum N_{t}^{i}=1$. This implies that the spot wage each period is $w_{t}=\omega^{n}\left(\Theta_{t}\right) \times \sum \mathbb{N}^{i}\left(Z_{t}^{i}, k_{t}^{i}, N_{t-1}^{i}, \bar{w}_{t-1}^{i} ; \Theta_{t}\right)$. Note that once our algorithm has converged, as long as the $R^{2}$ (discussed below) is sufficiently high, the belief is consistent with the spot wage: $w_{t} \approx \omega^{n}\left(\Theta_{t}\right)$. However, before convergence we are able to pick the spot wage in any period so as to clear 
markets. ${ }^{7}$

Once the simulation is complete, we have a time series for all relevant aggregate variables. We use these time series to update the beliefs. (Krusell and Smith 1998) have suggested regressing the relevant variables on the state variables. However we find this problematic in our setting because linear regressions imply strange behavior "off-equilibrium," which leads to problems in the value-function iteration step. Adding higher-ordered terms does not help because it leads to overfitting.

We propose an alternative, nonparametric approach. Rather than defining the belief as a parametric function of the state space variables, we will define a belief separately for each grid point in the aggregate state space. Before getting into the specifics, the basic idea is to define the belief about a variable at a point in the state space as the typical value of that variable in all simulated data near that point.

Recall that the aggregate state space is a triple $\Theta_{t}=\left\{x_{t}, k_{t}, \bar{w}_{t-1}\right\}$. First, we separate all grid points on the aggregate state space into two types: those that are near where the simulated data resides ("on-equilibrium") and those that are not ("off-equilibrium"). We define a grid point as "on-equilibrium" if there are more than 20 periods during the simulation, in which i) the discrete aggregate productivity state $x_{t}$ in simulation is identical to the one at the grid point, and ii) the distance between the simulated $k_{t}$ and the state is less than one standard deviation of the simulated $k$. All other points are defined as "off-equilibrium points". ${ }^{8}$ Our procedure for defining beliefs is different for the two types of points.

If a point is "on-equilibrium", we run a regression of our variables of interest (consumption, output, and the spot wage) on the state variables $\left\{k_{t}, \bar{w}_{t-1}\right\}$, but only among periods in which conditions i) and ii) above are satisfied. The predicted value of our variable of interest computed at the grid point is then our updated belief at this grid point. Note that this is very similar to the (Krusell and Smith 1998) approach, with the difference being that they run a regression using all data, and we run separate regressions for each point in the state space, using only data close to that point.

For the remaining "off-equilibrium" grid points, the procedure of computing beliefs is more complicated, because the simulated data may not be a good estimate of how the model would behave at this point. Instead of running a regression using simulated data, we start the model off exactly at the "off-equilibrium" grid point (recall this is just a triple $\Theta_{t}=\left\{x_{t}, k_{t}, \bar{w}_{t-1}\right\}$ ), and we simulate it for one period to compute the belief about our variables of interest (consumption, output, and the spot wage). One complication is that to simulate the model starting from

\footnotetext{
${ }^{7}$ For example, suppose that in state 1 , the belief is that the spot wage is 0.3 and the average firm's labor demand is 1.1. In this case, during simulation, the spot wage would be set to 0.33 , so that $1.1 \frac{0.3}{0.33}=1.0$ and the average firm would hire 1.0 workers. In the following iteration, the belief about the spot wage in state 1 would be revised up from 0.3 towards 0.33 .

${ }^{8}$ We have experimented with the definition of "on-equilibrium" by using alternative measures of distance and, for reasonable measures, this does not affect our results.
} 
this grid point, we must know not only the average capital and past wage, but also on the entire distribution of capital, past wage, past labor, debt obligations, and productivity across firms. We do this in the following way. We find the period in the simulated data that is closest to the grid point. We define closest as the smallest root-mean-square distance computed for $\left\{k_{t}, \bar{w}_{t-1}\right\}$ among points with the same discrete aggregate productivity state $x_{t}$ as the grid point. We then shift the mean of the distribution of capital and past labor from that period to match the level of the "off-equilibrium" grid point $\left\{k_{t}, \bar{w}_{t-1}\right\}$. For example, suppose the grid point has capital and past wage $\left(k_{a}, \bar{w}_{a}\right)$. Suppose the nearest simulated period has distributions of capital and past wages with average values $\left(k_{b}, \bar{w}_{b}\right)$. Then each firm's capital and average wage are shifted by $k_{b}-k_{a}$ and $\bar{w}_{b}-\bar{w}_{a}$. We then take the shifted distribution as an initial distribution and simulate it forward for one period.

There is one additional caveat. It is important to put a weight on old beliefs during updating; without it the procedure may not converge. We have found that the lower the capital adjustment cost, the higher the required weight. For zero adjustment cost, the weight may sometimes need to be as high as 0.998 . For our baseline model, the weight we use is 0.85 , and likely an even lower weight would have sufficed. ${ }^{9}$

The procedure above describes how to form updated beliefs for output, spot wages, and consumption as a function of the state. These updated beliefs are $y_{t}=\sum y_{t}^{i}=\vartheta^{n+1}\left(\Theta_{t}\right), w_{t}=\omega^{n+1}\left(\Theta_{t}\right)$, and $c_{t}=\zeta^{n+1}\left(\Theta_{t}\right)$. Noting that $i_{t}=y_{t}-c_{t}$ and plugging these into equation $\mathrm{A} 7$, the firm can use these beliefs to compute the aggregate state next period.

It still remains to update the belief for the stochastic discount factor. Note that with CRRA utility, this would be straightforward: $\mathbb{M}^{n+1}\left(\Theta_{t}, j_{t+1}\right)=\beta\left(\frac{Z_{t+1}}{Z_{t}}\right)^{-\rho \theta}\left(\frac{\zeta^{n+1}\left(\Theta_{t+1}\right)}{\zeta^{n+1}\left(\Theta_{t}\right)}\right)^{-\frac{1}{\psi}}$, where $j_{t+1}$ is the discrete realization of the aggregate productivity shock. For the more general case, we instead set

$\mathbb{M}^{n+1}\left(\Theta_{t}, j_{t+1}\right)=\beta\left(\frac{Z_{t+1}}{Z_{t}}\right)^{-\rho \theta}\left(\frac{\zeta^{n+1}\left(\Theta_{t+1}\right)}{\zeta^{n+1}\left(\Theta_{t}\right)}\right)^{-\frac{1}{\psi}}\left(\frac{u\left(\Theta_{t+1}\right)}{E_{t}\left[\left(\frac{Z_{t+1}}{Z_{t}}\right)^{\rho(1-\theta)} u\left(\Theta_{t+1}\right)^{1-\theta}\right]^{\frac{1}{1-\theta}}}\right)^{\frac{1}{\psi}-\theta}$,

where $u\left(\Theta_{t}\right)$ comes from separately solving the recursion:

$$
u\left(\Theta_{t}\right)=\left((1-\beta) \zeta^{n+1}\left(\Theta_{t}\right)^{1-\frac{1}{\psi}}+\beta E_{t}\left[\left(\frac{Z_{t+1}}{Z_{t}}\right)^{\rho(1-\theta)} u\left(\Theta_{t+1}\right)^{1-\theta}\right]^{\frac{1-\frac{1}{\psi}}{1-\theta}}\right)^{\frac{1}{1-\frac{1}{\psi}}} .
$$

\footnotetext{
${ }^{9}$ This is because even if rational equilibria exist, they are only weakly stable in the sense described by (Marcet and Sargent 1989).
} 
This recursion is also solved with value function iteration using the same aggregate grids as the firm's problem. However, it typically takes less than a second because the state space is much smaller (there are no individual firm variables), and because there are no choice variables.

Finally, we must update the bond pricing functions. We use the newly updated stochastic discount factor to compute the recursion in equation A12 by value function iteration. This recursion has both aggregate and individual state variables, however it has no choice variables. As inputs, it uses the value and default functions from the solution to the firm's problem.

Once steps one and two are complete, we check whether the algorithm has converged. If it has not, we restart step one with updated beliefs. Convergence means that the absolute distance between $\vartheta^{n+1}\left(\Theta_{t}\right)$ and $\vartheta^{n}\left(\Theta_{t}\right)$ is sufficiently small (same for $\zeta^{n+1}\left(\Theta_{t}\right)$ and $\omega^{n+1}\left(\Theta_{t}\right)$ ).

In addition to confirming that the beliefs have converged, it is standard to perform other checks. This solution method is referred to as an approximate bounded rational equilibrium. It is rational because the beliefs of the firms and agents are exactly equal to the best forecast an econometrician could achieve with in simulated data using the state defined variables. However, it is bounded because the forecast may still not be very good, as evidenced by a low $R^{2}$.

The lowest $R^{2}$ in our forecasting equations is 0.998 for consumption, the others are both above 0.999. ${ }^{10}$

There is one final component of the algorithm worth discussing. Typically, within each outer iteration, the value function iteration in step one would be implemented until convergence of the value function, before moving on to step two. To speed up the algorithm, this is not what we do. During step one of outer iteration $n$, we iterate the value function for 5 iterations before moving on to step two. Of course, 5 iterations is not enough for the value function to fully converge. However, during step $n+1$, we initialize the value function to be the final value function from the $n$ iteration, $v^{n}\left(\Theta_{t}^{i}, \Theta_{t}\right)$. Thus, rather than waiting for the value function to fully converge, before updating beliefs, we update the value function a bit at a time, then update beliefs, then update the value function a bit more, and so on. Thus, over $n$ outer iterations, the value function is iterated $5 n$ times. Once the beliefs, which are inputs into step one, have converged, this algorithm produces exactly the same result as if we waited for the value function to converge during each outer iteration. However, this process works much faster.

\section{B1. Other checks}

We have used the algorithm to solve several special cases of the model to confirm that where we know the exact solution, the algorithm gives us the same result.

\footnotetext{
${ }^{10}$ Because we apply a nonparametric approach, we define the $R^{2}=1-\frac{\sum\left(x_{t}-E\left[x_{t} \mid \Theta_{t}\right]\right)^{2}}{\sum\left(x_{t}-E\left[x_{t}\right]\right)^{2}}$ where $E\left[x_{t}\right]$ is the unconditional mean of $x$ and $E\left[x_{t} \mid \Theta_{t}\right]$ is our forecast of $x$, using the beliefs. More specifically, consider the spot wage. $E\left[w_{t} \mid \Theta_{t}\right]$ is a linear interpolation of the spot wage, using the belief $\omega^{n}\left(\Theta_{t}\right)$ at the aggregate state grid points around the simulated realization of $\Theta_{t}$.
} 
Case 1: A partial equilibrium problem where the stochastic discount factor $M_{t+1}$ and the spot wage $W_{t}$ are exogenously specified. There is no debt. Returns to scale are constant $\rho=1$, and the production function is Cobb-Douglas $\eta=0$. For convenience, we do not differentiate between the aggregate and individual shock, so that both are in $Z_{t} . W B_{t}=\bar{W}_{t} N_{t}$ is the firm's wage bill at $t$. The firm's problem is:

$$
\begin{array}{rl}
V\left(Z_{t}, K_{t}, N_{t-1}, W B_{t-1}\right)= & Z_{t} K_{t}^{\alpha} N_{t}^{1-\alpha}-W B_{t}-I_{t}-v\left(\frac{I_{t}}{K_{t}}-\delta\right)^{2} K_{t}+ \\
& E_{t}\left[M_{t+1} V\left(Z_{t+1}, K_{t+1}, N_{t}, W B_{t}\right)\right] \\
K_{t+1} & (1-\delta) K_{t}+I_{t} \\
W B_{t} & W B_{t-1} \mu+\left(N_{t}-N_{t-1} \mu\right) W_{t}
\end{array}
$$

It can be shown that the value function has the form

$$
V\left(Z_{t}, K_{t}, N_{t-1}, W B_{t-1}\right)=Q_{t}^{K} K_{t}+Q_{t}^{N} N_{t}+Q_{t}^{W B} W B_{t}
$$

where the $Q_{t}^{N}=-W_{t} Q_{t}^{W B}$, while $Q_{t}^{W B}$ and $Q_{t}^{K}$ follow the recursions:

$$
Q_{t}^{W B}=\mu\left(E_{t}\left[M_{t+1}\left(Q_{t+1}^{W B}-1\right)\right]\right.
$$

and

$Q_{t}^{K}=S_{t}\left(Z_{t} S_{t}^{-\alpha}-W_{t}+E_{t}\left[M_{t+1}\left(W_{t}-W_{t+1}\right) Q_{t+1}^{W B}\right]\right)-\delta+v\left(\frac{E_{t}\left[M_{t+1} Q_{t+1}^{K}\right]-1}{2 v}\right)^{2}+E_{t}\left[M_{t+1} Q_{t+1}^{K}\right]$

and $S_{t}$ is defined as

$$
S_{t}=\left(\frac{W_{t}+E_{t}\left[M_{t+1} Q_{t+1}^{W B}\left(W_{t+1}-W_{t}\right)\right]}{(1-\alpha) Z_{t}}\right)^{-1 / \alpha}
$$

Note that if we specify laws of motion for $Z_{t+1}, M_{t+1}$, and $W_{t+1}$ as a function of some underlying state, it is straight forward to solve the recursions in equations B3 and B4 numerically (there are no choice variables, so this is not only easy but also fast). Conditional on solving the recursions, we can solve the firm's problem analytically. We have compared this analytic solution to our model's numerical solution for several reasonable $\left(Z_{t+1}, M_{t+1}, W_{t+1}\right)$ and the numerical solution is very close to the analytic solution.

Case 2: Similar to Case 1 but there are no capital adjustment costs $(v=0)$, instead we allow for decreasing return to scale $\rho<1$. Note that we cannot analytically solve the case with both capital adjustment costs and decreasing 
returns to scale.

$$
\begin{array}{rl}
V\left(Z_{t}, K_{t}, N_{t-1}, W B_{t-1}\right)= & Z_{t} K_{t}^{\alpha} N_{t}^{\rho(1-\alpha)}-W B_{t}-I_{t}+ \\
& E_{t}\left[M_{t+1} V\left(Z_{t+1}, K_{t+1}, N_{t}, W B_{t}\right)\right] \\
K_{t+1} & (1-\delta) K_{t}+I_{t} \\
W B_{t} & W B_{t-1} \mu+\left(N_{t}-N_{t-1} \mu\right) W_{t}
\end{array}
$$

It can be shown that the value function has the form

$$
V\left(Z_{t}, K_{t}, N_{t-1}, W B_{t-1}\right)=Q^{0}+Q_{t}^{1} K_{t}^{\psi}+Q_{t}^{2} K_{t}+Q_{t}^{N} N_{t}+Q_{t}^{W B} W B_{t}
$$

where $\psi=\frac{\alpha}{1-\rho(1-\alpha)} ; Q_{t}^{N}$ and $Q_{t}^{W B}$ are defined the same as in Case $1, Q^{2}=1-\delta$, and

$$
\begin{aligned}
Q_{t}^{1} & =S_{t}\left(Z_{t} S_{t}^{(1-\alpha) \rho-1}-W_{t}+E_{t}\left[M_{t+1}\left(W_{t}-W_{t+1}\right) Q_{t+1}^{W B}\right]\right) \\
S_{t} & =\left(\frac{W_{t}+E_{t}\left[M_{t+1} Q_{t+1}^{W B}\left(W_{t+1}-W_{t}\right)\right]}{(1-\alpha) Z_{t}}\right)^{\frac{-1}{1-\rho(1-\alpha)}}
\end{aligned}
$$

and

$$
\begin{aligned}
Q_{t}^{0} & =E_{t}\left[M_{t+1} Q_{t+1}^{0}\right]-X_{t}+E_{t}\left[M_{t+1} Q_{t+1}^{1}\right] X_{t+1}^{\psi}+E_{t}\left[M_{t+1} Q_{t+1}^{2}\right] X_{t} \\
X_{t} & =\left(\frac{1+E_{t}\left[M_{t+1} Q_{t+1}^{2}\right]}{\psi E_{t}\left[M_{t+1} Q_{t+1}^{1}\right]}\right)^{\frac{1}{\psi-1}}
\end{aligned}
$$

As with Case 1, we have compared this analytic solution to our model's numerical solution for several reasonable $\left(Z_{t+1}, M_{t+1}, W_{t+1}\right)$ and the numerical solution is very close to the analytic solution.

Case 3: If the conditions of the First Welfare Theorem hold, then a decentralized problem should give us the same solution as the planner's problem. If we shut down the appropriate frictions in the model $(\mu=0, \tau=0)$ these conditions hold. In this case, for the parameters of our baseline model, we have checked that our decentralized algorithm gives a very similar solution as a solution using the planner's method. While this is not a proof that the algorithm works, the planner's method is a relatively straight forward, established technique. Furthermore, we have used the same planner's method algorithm to replicate certain existing published papers, in particular (Prescott 1986), and (Kaltenbrunner and Lochstoer 2010). The latter is a model with capital, adjustment costs, inelastic labor, and long run risk - relatively similar to a frictionless version of our baseline model.

\section{VALUE, POLICY, AND IMPULSE RESPONSE FUNCTIONS}

In this subsection we plot several sample value and policy functions. The state space is multidimensional and plotting the entire value function is infeasible, for this reason we focus on a particular region within the state space. We set capital 
$k_{t}$, past wage $\bar{w}_{t-1}$, and expected productivity growth $x_{t}$ to their simulated means; we also set the firm's past employment $N_{t-1}^{i}$ and idiosyncratic productivity $Z_{t}^{i}$ to their simulated means. We plot policy and value functions for different values of the firm's capital $K_{t}^{i}$, past average wage $\bar{w}_{t-1}^{i}$, and current coupon payment $\bar{\kappa}_{t}^{i}$.

The top two panels of Figure A1 plot the quarterly investment-to-capital ratio as a function of (detrended) firm capital. As a point of reference, the average (detrended) capital in the model is 3.1. The solid line in both the left and right panels is a firm whose past average wage, and current coupon payment are equal to the simulated means. The investment-to-capital ratio is decreasing in capital, except for very low levels of capital. ${ }^{11}$ The dotted and dashed lines in the left panel represent the same firm but with low, or high past average wages; recall that past average wages are a proxy for future wage obligations. Firms with low past wages invest relatively more, while firms with high past wages relatively less. The dotted and dashed lines in the right panel represent the same firm but with zero debt, or above average current interest expenses. Firms with no current coupon payments invest relatively more, and those with high coupon payments relatively less - this is the classic debt overhang problem of (Myers 1977). The bottom two panels are analogous to the top two, but show employment rather than investment policy. As with investment, firms with high coupon or wage obligations choose fewer employees. The sharp drop off at low capital represents default, discussed below.

The top two panels of Figure A2 plot the firm's equity value as a function of (detrended) firm capital. As above, the top left panel plots a firm with low, average, or high past average wages; the top right panel plots a firm with zero, average, or high current coupon payments. Both high past wages and high current debt obligations reduce the firm's equity value. Firms default if their equity value is zero, and this may happen even if they have positive capital. For the same level of capital, a firm with high coupon payments, or high past wages is more likely to default. The bottom left panel shows the price of debt (whose coupon payment is equal to the simulated average) for a firm with low, average, or high past wages. The debt of firms with more capital is worth more, as there is more collateral. The debt of firms with high past wages is worth less, as these firms are more likely to see their value erode due to high wage obligations, and to subsequently default. Note that there is a kink in the price of debt at the point where the firm defaults. Finally, the bottom right panel shows the debt issuance policy of firms with low, average, or high past wages. Note that only firms with zero current debt obligations may issue new debt, all other firms maintain their current level of debt. Firms with more capital issue more debt, but conditional on the same

\footnotetext{
${ }^{11}$ If a firm with average coupon and wage payments has a very low level of capital, it is better off shutting down as the obligations are too high relative to expected future cash flows. However, due to adjustment costs, it is better to deaccumulate capital slowly over time, then to shut down immediately. This is why, unlike in more standard models, investment is low when capital is low. When the firm has no current debt obligations (dotted line in the top right panel), the firm's investment-to-capital ratio is highest when capital is low, confirming standard intuition.
} 
level of capital, firms with higher past wages issue less debt.

We also plot the impulse response functions for the wage, EBITDA (this is economic profit, before taxes or payments to creditors are subtracted), labor share, financial leverage, the credit spread, and investment in Figure A3 for the baseline model, and Figure A4 for the Cobb-Douglas model with no rigidity. This is done for an average initial conditions (All), as well as initial conditions with high or low labor share, or high or low financial leverage (labor share is constant for the second model, so we condition on leverage only).

First, consider the average response only, and compare the two models. In the frictionless, Cobb-Douglas model, after a negative shock, wages and EBITDA fall immediately by exactly the same amount, and are afterwards constant, resulting in a constant labor share. In the baseline model, wages fall by far less on impact, and then continue to fall slowly. Because wages fall slowly, the labor share rises, and EBITDA falls by much more in this model. Thus the capital owners - debt and equity - absorb a much larger fraction of the negative shock. This is the same channel as in (Favilukis and Lin 2016), who show that it is consistent with the data, where profit is also much more responsive to shocks than wages. Investment falls, the credit spread rises, and leverage rises ${ }^{12}$ on impact. In percentage terms these changes are about the same in the two models, although the initial levels of credit spread and leverage are different. However, the baseline model delevers more quickly because long term labor obligations make leverage riskier.

Next, consider conditioning on high initial labor share in the baseline model. Initial wages are low (this is somewhat counterintuitive but occurs because labor share is typically high during bad times), as are initial profits and investment. Initial financial leverage is close to its unconditional average when labor share is high, however following a negative shock, firms delever very quickly - this delevering happens through both less new issuance and default. This can be compared to the very slow delevering in the case of low initial labor share despite a negative shock, financial leverage is not particularly risky because labor leverage is low. On the other hand, the initial credit spread is high because high labor obligations leave less for creditors to claim, but it falls very fast as firms delever. Labor share is constant in the frictionless, Cobb-Douglas model, thus the model is unable to speak to these interesting interactions between labor leverage and credit risk.

\section{TWO-PERIOD MODEL}

In this section, we solve a two period, partial equilibrium model that is, otherwise, as similar as possible to our baseline model. This model can qualitatively match the key results in our main model: a positive relationship between labor obligations and credit risk, and a negative relationship between labor obligations and debt issuance. Because this model is far less complicated than our baseline

\footnotetext{
${ }^{12}$ Leverage rises because the output, and firm value, which is the denominator, falls.
} 
model, it may be easier to understand the intuition by focusing on this model.

The firm lives for two periods only, $t$ and $t+1$. The firm enters period $t+1$ with the following state variables: productivity $Z_{t+1}$, capital $K_{t+1}$, face value of outstanding debt $B_{t+1}$, previous period employees $N_{t}$, and the previous period average wage $\bar{W}_{t}$. The firm's problem at $t+1$ is:

(D1)

$V_{t+1}\left(Z_{t+1}, K_{t+1}, B_{t+1}, \bar{W}_{t}, N_{t}\right)=\max \left(0, \max _{N_{t+1}} Z_{t+1} K_{t+1}^{\alpha} N_{t+1}^{1-\alpha}-\bar{W}_{t+1} N_{t+1}+K_{t+1}-B_{t+1}\right)$

where the wage bill depends on the average past wage $\bar{W}_{t}$, past employees $N_{t}$, and the current spot wage $W_{t+1}$ :

$$
\bar{W}_{t+1} N_{t+1}=W_{t+1}\left(N_{t+1}-N_{t} \mu\right)+\bar{W}_{t} N_{t} \mu
$$

We assume that the spot wage is perfectly correlated with productivity $W_{t+1}=$ $(1-\alpha) Z_{t+1}$, which implies that $N_{t+1}=K_{t+1}$ and that the firm's value function at $t+1$ is:

$V_{t+1}\left(Z_{t+1}, K_{t+1}, B_{t+1}, \bar{W}_{t}, N_{t}\right)=\max \left(0, \alpha Z_{t+1} K_{t+1}+K_{t+1}-B_{t+1}-\mu N_{t}\left(\bar{W}_{t}-(1-\alpha) Z_{t+1}\right)\right)$

Thus, the firm's equity value at $t+1$, is a simple, linear function of the state variables. At $t$, the firm takes the $t+1$ continuation value as given, and chooses how much to invest, hire, and borrow. It enters $t$ with productivity $Z_{t}=1$, capital $K_{t}=1$, past employees $N_{t-1}$, and past wage $\bar{W}_{t-1}$. The firm faces a trade-off between tax shields and bankruptcy costs.

Define next period's capital, the average wage, and the pre-tax profit as:

$$
\begin{aligned}
& K_{t+1}=(1-\delta) K_{t}+I_{t} \\
& \bar{W}_{t} N_{t}=W_{t}\left(N_{t}-N_{t-1} \mu\right)+\bar{W}_{t-1} N_{t-1} \mu \\
& \Pi_{t}=Z_{t} K_{t}^{\alpha} N_{t}^{1-\alpha}-\bar{W}_{t} N_{t}
\end{aligned}
$$

The firm's problem is:

$$
\begin{aligned}
V_{t}\left(Z_{t}, K_{t}, \bar{W}_{t-1}, N_{t-1}\right) & =\max _{I_{t}, N_{t}, B_{t+1}} \Pi_{t}(1-\tau)-I_{t}-v\left(\frac{I_{t}}{K_{t}}-\delta\right) K_{t} \\
& +Q_{t} B_{t+1}+\min \left(\tau\left(1-Q_{t}\right) B_{t+1}, \tau \Pi\right) \\
& +E_{t}\left[M_{t+1} V_{t+1}\left(Z_{t+1}, K_{t+1}, B_{t+1}, \bar{W}_{t}, N_{t}\right)\right]
\end{aligned}
$$

where the first piece on the right is after tax profit, the second and third pieces are investment and adjustment costs, the fourth piece is proceeds from issuance of new debt, the fifth piece is the interest tax deduction, and the sixth piece is the continuation value.

Simultaneously we need to solve for the bond price. Define the indicator $\mathbf{1}_{D}$ to be 1 when $V_{t+1}\left(Z_{t+1}, K_{t+1}, B_{t+1}, \bar{W}_{t}, N_{t}\right) \leq 0$ and zero otherwise. Then we can 
define the price of debt as:

$$
Q_{t}\left(K_{t+1}, \bar{W}_{t}, N_{t}, B_{t+1}\right)=E_{t}\left[M_{t+1}\left(\mathbf{1}_{D}+\left(1-\mathbf{1}_{D}\right) \frac{V_{t+1}^{0}}{B_{t+1}}\right)\right]
$$

where

$$
V_{t+1}^{0}=\left(Z_{t+1} K_{t+1}+K_{t+1}-\mu N_{t}\left(\bar{W}_{t}-(1-\alpha) Z_{t+1}\right)\right)(1-\theta)
$$

is the post-default firm value that goes to the creditors, and $\theta$ is the default cost. Note that like in our full model, the price of debt $Q_{t}$ is a function of the choices that the firm makes at $t$.

If debt is forced to be zero, then this problem can be solved analytically, with $\frac{I_{t}}{K_{t}}=\frac{\alpha E_{t}\left[M_{t+1} Z_{t+1}\right]+E_{t}\left[M_{t+1}\right]-1}{2 v}$ and $N_{t}=K_{t}\left(1+\mu\left(E_{t}\left[M_{t+1}\right]-E_{t}\left[M_{t+1} Z_{t+1} / Z_{t}\right]\right)\right)^{-1 / \alpha}$. Because the interaction between bankruptcy, the price of debt, and firm choices is complicated, we solve the full problem numerically.

We assume that the stochastic discount factor is $\beta\left(\frac{Z_{t+1}}{Z_{t}}\right)^{-\gamma}$ and we choose the following parameters: $\alpha=0.4, \delta=0.1, v=1.0, \beta=0.8, \gamma=0.5, \mu=0.9$, $\tau=0.35$, and $\theta=0.17$. We choose $Z_{t+1}$ to be normal with mean one and standard deviation 0.25. In figure A5, we plot the amount of debt issued, the default rate, and the interest rate, as a function of the past average wage $\bar{W}_{t-1}$, while setting past labor $N_{t-1}=1$ at its frictionless value. We do this for four models.

The first model is the model described above, we call this the short term debt (STD) model because the firm is unconstrained as to how much debt to issue. As the firm's past average wage increases, it issues progressively less debt. This is consistent with our full model. This happens because, all else equal, high labor obligations from $t-1$ will still affect the ability to pay at $t+1$, making default more likely, interest rates higher, and debt less attractive. As labor obligations rise, the default rate and the interest rise as well. However, eventually, for high enough labor obligations, firms reduce debt by so much that they actually become safer, resulting in lower default rates and interest rates as a function of the past average wage - this is different from our baseline model.

To make debt in the model above more like long term debt, we assume that the firm enters period $t$ with an additional state variable $B_{t}$, which represents the long term level of debt. We assume that 25 percent of firms can change their debt, and behave just as the short term debt firms described above. The remaining firms must set $B_{t+1}=B_{t}{ }^{13}$ In figure A5, we plot, for the average firm, the amount of debt issued, default rate, and interest rate, as a function of the past average wage $\bar{W}_{t-1}$. We set past labor $N_{t-1}=1$ at its frictionless value. We do this for low, medium, and high debt firms. ${ }^{14}$ In this long term debt model, as the past

\footnotetext{
${ }^{13}$ To make the model comparable to the short term debt model, we assume that $B_{t}$ is not actually paid to creditors at $t$, its only purpose is to make deviations from past $B_{t}$ impossible for some firms.

${ }^{14}$ The medium $B_{t}=1.3$ is set to equal the optimal debt amount in the short term debt model, at the
} 
average wage rises, debt issuance falls, as in the short term debt model and in our full model. However, it falls much slower than in the short term debt model because many firms are unable to adjust their debt. As a result, the default rate and the interest rate rise even at higher levels of wage obligations. ${ }^{15}$

Thus, this simple two period model qualitatively reproduces our key results: a positive relationship between labor share and the credit spread, and a negative relationship between labor share and debt issuance. The intuition in the full model is the same, but it is also quantitatively close to the data.

\section{VARIABLE CONSTRUCTION}

\section{E1. Aggregate data}

Table A4 reports the descriptive statistics for the variables we use in our aggregate regressions. Note that wage growth is far less volatile than GDP growth evidence against a frictionless Cobb-Douglas model. The relationship between the credit spread, wage growth, and labor share is also evident in Figure A6, where credit spread moves together with labor share, and in the opposite direction of wage growth. The variable definitions are below.

- Credit spread. We use the Moody's Baa corporate bond yield in excess of Aaa corporate bond yield from the Federal Reserve. (Chen, Collin-Dufresne and Goldstein 2009) argue that the Baa-Aaa spread mostly reflects credit risk, because the components due to taxes, call/put/conversion options and liquidity are of similar magnitude for Aaa and Baa bonds.

- Debt growth. Aggregate debt growth is the growth rate of credit market instrument liabilities for non-financial corporate from the Flow of Funds Table L103. Although the most recent Table L103 does not report this as a separate item, this is also equal to the sum of debt securities and loans.

- Wage growth. We use the growth rate in the real wages and salaries per full-time equivalent employee from NIPA Table 6.6.

- Labor share. Labor share is the ratio of aggregate compensation of employees to GDP. Aggregate compensation is from NIPA and includes noncash benefits.

- Controls. The empirical finance literature has identified several variables related to the credit spread (see (Collin-Dufresne, Goldstein and Martin 2001)). We measure financial leverage as the book value of credit market instruments of nonfinancial business sector divided by the sum of the market

point where the past average wage is equal to the spot wage $\left(\bar{W}_{t-1}=0.6\right)$. The high and low values are 1.1 and 1.5 .

${ }^{15}$ There appears to be some non-monotonicity at intermediate values $W_{t-1}$. We do not have intuition for why this is so, but do not believe this is a mistake. 
value of equity in the nonfinancial corporate business sector and the book value of the credit market instruments from the Flow of Funds Accounts. Stock market volatility is the annualized volatility of monthly CRSP stock market returns in excess of risk free rate. Term spread is the difference between the ten-year Treasury bond yield and the three-month Treasury bill yield from the Federal Reserve. The spot rate is the one-year Treasure bill rate. The growths of GDP, consumption, and employment are from BEA. Our sample is from 1948 to $2014 .^{16}$

\section{E2. Firm level data}

Our firm-level control variables are constructed as follows:

- WCT A: Working capital is the ratio of Compustat item WCAP to total assets (Compustat item AT).

- RET A: Retained earnings is the ratio of Compustat item RE to total assets.

- EBITT A: EBIT is the ratio of Compustat item EBIT to total assets.

- Leverage: We define book leverage as $(D L T T+D L C) / A T$, where $D L T T$ and $D L C$ are Compustat items for long-term and short-term debt respectively. We also calculate an alternative measure using $(D L T T+D L C) /(D L T T+$ $D L C+A T+T X D I T C-P S T K-L T)$ but find that empirically the correlation between these two measures is high (95 percent correlation). Therefore we only report the results based on our main definition of book leverage. We define market leverage as $(D L T T+D L C) /(D L T T+D L C+P R C C *$ $C S H O)$, where $P R C C$ is the price per share and $C S H O$ is the shares outstanding.

- $S T$ A: Sales is the ratio of Compustat item SALE to total assets.

- NIT A: Net income is the ratio of Compustat item NI (for North America) and NICON (for Global) to total assets.

- $C A C L$ : Current ratio is the ratio of Compustat item ACT (current assets) to LCT (current liabilities).

- $\sigma$ : Stock return volatility is the standard deviation of monthly returns. For US and Canadian firms, we use data from Compustat North America Security Daily, and for firms in other countries, we use data from Compustat Global Security Daily, to calculate stock return in month $t$ as

$$
R E T_{t}=\frac{P R C C D_{t} / A J E X D I_{t} \times T R F D_{t}-P R C C D_{t-1} / A J E X D I_{t-1} \times T R F D_{t-1}}{P R C C D_{t-1} / A J E X D I_{t-1} \times T R F D_{t-1}}
$$

\footnotetext{
${ }^{16}$ We start in 1948 because financial leverage from Flow of Funds is available after 1946. We do not start in 1946 to avoid the influence of WWII on our results. However, the predictability of wage growth for the credit spread holds in a longer sample starting from 1929.
} 
where $P R C C D_{t}$ is the closing price at month end, $A J E X D I_{t}$ and $T R F D_{t}$ are the corresponding share and return adjustment factors.

- Invest: Investment ratio is defined as the ratio of Compustat item CAPX to lagged PPENT (Property, Plant and Equipment).

- MCAP: The market capitalization of a firm at year for is defined as the logarithm of the product of year end closing price (PRCCD) and shares outstanding (CSHOC).

- RSIZE: Relative size is defined as the logarithm of the ratio of company's market capitalization to the total market capitalization in its country at the year end. In other words, it is a company's weight in its country's value-weighted market portfolio.

- $R_{m}$ : The return on the value-weighted market portfolio for each country at annual frequency.

- $R_{\text {excess }}:$ The excess return of a firm's stock is defined as the difference between firm's raw return $(R E T)$ and the value-weighted market portfolio return $\left(R_{m}\right)$.

- $H N$ : Net hiring is defined as $H N_{t}=\frac{\left(E M P_{t}-E M P_{t-1}\right)}{0.5 \times\left(E M P_{t}+E M P_{t-1}\right)}$, where EMP is the number of employees from Compustat.

- $\triangle W A G E$ : Wage growth is defined as $\Delta W A G E_{t}=\frac{\left(W A G E_{t}-W A G E_{t-1}\right)}{0.5 \times\left(W A G E_{t}+W A G E_{t-1}\right)}$, where $W A G E=X L R / E M P$.

\section{E3. CDS data}

We obtain the single name corporate CDS spread data from IHS Markit. We discuss below how we link the Markit identifiers to the Compustat Global identifies and the sample coverage.

The main Markit identifiers that might be used to link to other databases are company name and company (6-digit) CUSIP. In Compustat Global, the identifier that might be matched to Markit is company name. Note that for North American firms, we can extract the historical CUSIP (NCUSIP) from CRSP and used it to match with the company CUSIP in Markit. Therefore, we conduct a multi-step matching process to create the linking table between Markit and Compustat Global. First, for North American firms, we match the CUSIP from Markit with the NCUSIP (6-digit) from the CRSP to obtain the corresponding PERMCO which is then used to obtain the GVKEY for Compustat. Second, for firms outside North America, we match the company name from Markit with the company name from Compustat Global and only keep the exact matches to obtain the GVKEY from Compustat. Third, for the remaining firms outside North America, we use a name match algorithm in Python to generate scores 
between the Markit company name and the Compustat Global company name. We keep the firms with scores above 0.5 and manually go through them to identify the correct matches. For the unmatched firms and the firms with lower than 0.5 matching scores, we use the Capital IQ ID look-up function to extract the GVKEY directly by using Markit company name as the input. To check the accuracy of the Capital IQ look-up function, we use the exact name matches that we identify from the previous step as an experiment sample. We find that for this exactmatch subsample, Capital IQ look-up function has a success rate of 92 percent. For the Capital IQ ID look-up step, sometimes it will return multiple GVKEYs, and we manually filter out the correct ones in these cases. After going through the whole matching process and keeping firms with at least 1 non-missing labor expenses growth rate, we have 1006 unique firms left in the CDS sample with non-missing GVKEYs.

For each firm date in the CDS dataset, there might be multiple observations representing different CDS contracts. The main variables that characterize these contracts are Tier, DocClause, and Ccy (currency). We select the CDS contracts following the literature ((Longstaff, Mithal and Neis 2005); (Zhang, Zhou and Zhu 2009); (Augustin et al. 2014); (Bai and Wei 2017)). For example, Tier represents the seniority of the underlying debt that the CDS contract is written on. For the matched CDS sample more than 96 percent of the observations have the Tier value as SNRFOR, which represents senior unsecured debt. Therefore, we keep only the CDS contracts with Tier of SNRFOR.

Second, DocClause represents the document clause and restructuring type that the CDS is priced on. This defines what constitutes a credit event for the contract as well as any limitations on the deliverable debt in the event of a credit event. This variable follows the ISDA (International Swap and Derivative Association) definitions (2003 and 2014 versions) and have four different types: CR - Full Restructuring, MR - Modified Restructuring, MM - Modified Modified Restructuring, and XR - No Restructuring. ${ }^{17}$ We follow the literature to use the main DocClause for different regions/different years. For example, for North American firms, we use MR before 2009 and XR after 2009 (due to CDS big bang). To increase the sample coverage, we use CDS contracts with our DocClause when the primary ones do not have CDS spreads available. Specifically, for the North American firms, if MR is not available before 2009, we use other DocClause in the sequence of $\mathrm{XR}, \mathrm{CR}$, and $\mathrm{MM}$ (this also reflects a descending coverage percentage order in the data). For the North American firms after 2009, if XR is not available, we use other DocClause in the sequence of MR, CR, and MM. For other regions, the DocClause convention varies because of differences in bankruptcy laws. For European firms, MM is the most common one, followed by CR, MR, and XR, so this is also the sequence we use to find the CDS contracts with non-missing spreads. For Asian and other emerging markets, we use the sequence of CR, MR, MM14, and XR. And for Oceanian markets, we use the sequence of MR, CR,

\footnotetext{
${ }^{17}$ See (Bai and Wei 2017) for more detailed discussions.
} 
MM, and XR.

Third, when a CDS contract is traded in multiple currencies, the CDS spreads are the same as these are expressed as basis points of 100 currency units of the notional amount. So we only need to use one CDS spread when a contract is traded in multiple currencies.

After filtering through the above CDS contract features, we have one CDS contract left for each firm date. We follow the literature (e.g.,(Longstaff, Mithal and Neis 2005)) to use the most liquid CDS contracts spread, 5-year CDS spreads as our main measure, and we also conduct the analysis using 1-year CDS spreads, which also has decent coverage. For example, 93 percent of our sample has nonmissing 5-year CDS spread and 83 percent of the sample has non-missing 1-year CDS spread.

\section{REFERENCES}

Augustin, Patrick, Marti Subrahmanyam, Dragon Tang, and Sarah Wang. 2014. "Credit Default Swaps: A Survey." Foundations and Trends in Finance, 9: 1-196.

Bai, Jennie, and Shang-Jin Wei. 2017. "Property rights and CDS spreads: when is there a strong transfer risk from the sovereigns to the corporates?" Quarterly Journal of Finance, 7(4): 1-36.

Chen, Long, Pierre Collin-Dufresne, and Robert Goldstein. 2009. "On the Relation Between the Credit Spread Puzzle and the Equity Premium Puzzle." Review of Financial Studies, 22: 3367-3409.

Collin-Dufresne, Pierre, Robert Goldstein, and Spencer Martin. 2001. "The Determinants of Credit Spread Changes." Journal of Finance, 56(6): 21772207.

Favilukis, Jack, and Xiaoji Lin. 2016. "Does Wage Rigidity Make Firms Riskier? Evidence From Long Horizon Return Predictability." Journal of Monetary Economics, 78: 80-95.

Kaltenbrunner, Georg, and Lars Lochstoer. 2010. "Long-Run Risk through Consumption Smoothing." Review of Financial Studies, 23: 3141-89.

Krusell, Per, and Anthony Smith, Jr. 1998. "Income and Wealth Heterogeneity in the Macroeconomy." The Journal of Political Economy, 106(5): 86796.

Longstaff, Francis., Sanjay. Mithal, and Eric Neis. 2005. "Corporate yield spreads: default risk or liquidity? New evidence from the credit default swap market." Journal of Finance, 6(5): 2213-53.

Marcet, Albert, and Thomas Sargent. 1989. "Convergence of Least Squares Learning Mechanisms in Self-Referential Linear Stochastic Models." Journal of Economic Theory, 48: 337-68. 
Myers, Stewart. 1977. "Determinants of Corporate Borrowing." Journal of Financial Economics, 5: 147-75.

Newey, Whitney, and Kenneth West. 1987. "A Simple, Positive Semidefinite, Heteroskedasticity and Autocorrelation Consistent Covariance Matrix." Econometrica, 55(3): 703-8.

Prescott, Edward. 1986. "Theory Ahead of Business Cycle Measurement." Federal Reserve Bank of Minneapolis Staff Report.

Zhang, Benjamin, Hao Zhou, and Haibin Zhu. 2009. "Explaining credit default swap spreads with the equity volatility and jump risks of individual firms." Review of Financial Studies, 22(12): 5099-131. 

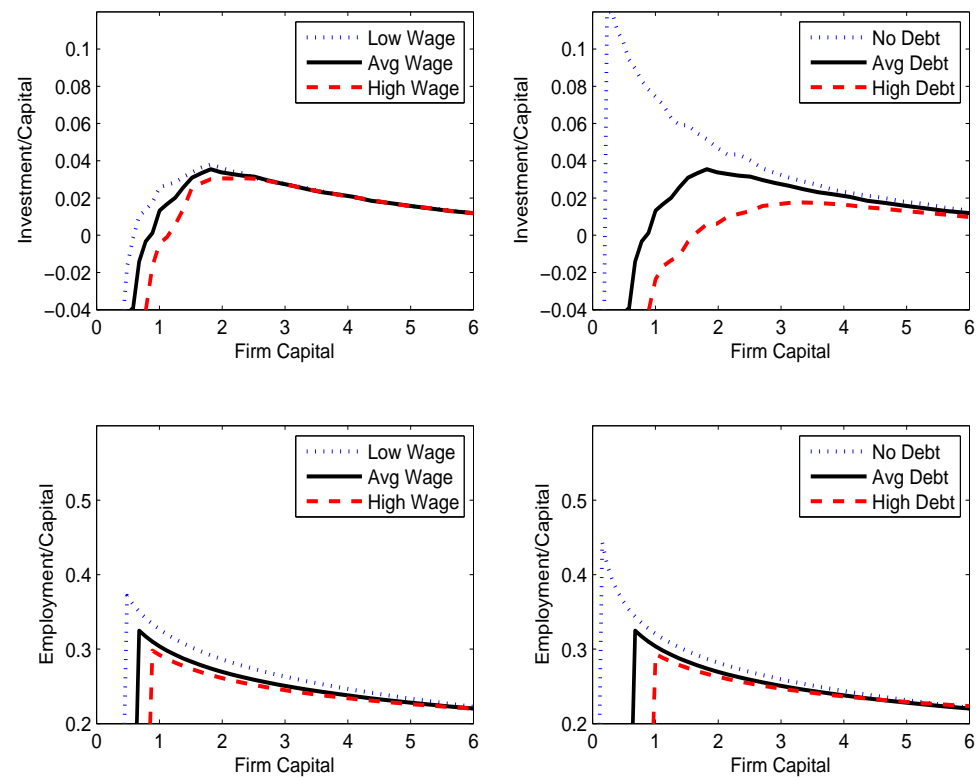

Figure A1. Policy functions.

Note: This figure plots policy functions for the investment-to-capital ratio (top two panels), and the labor demand-to-capital ratio (bottom two panels), as functions of capital. The state variables $z_{t}, k_{t}$, $\bar{w}_{t-1}, Z_{t}^{i}$ and $N_{t}^{i}$ are set to their simulated means. The state variable $\bar{\kappa}_{t}^{i}$ is set to 0 , or 0.06 , or 0.10 , corresponding to no debt, average debt (Avg Debt) and high debt, respectively. The state variable $\bar{w}_{t-1}^{i}$ is set to 0.16 , or 0.20 , or 0.24 , corresponding to low wage, average wage (Avg Wage) and high wage, respectively. 

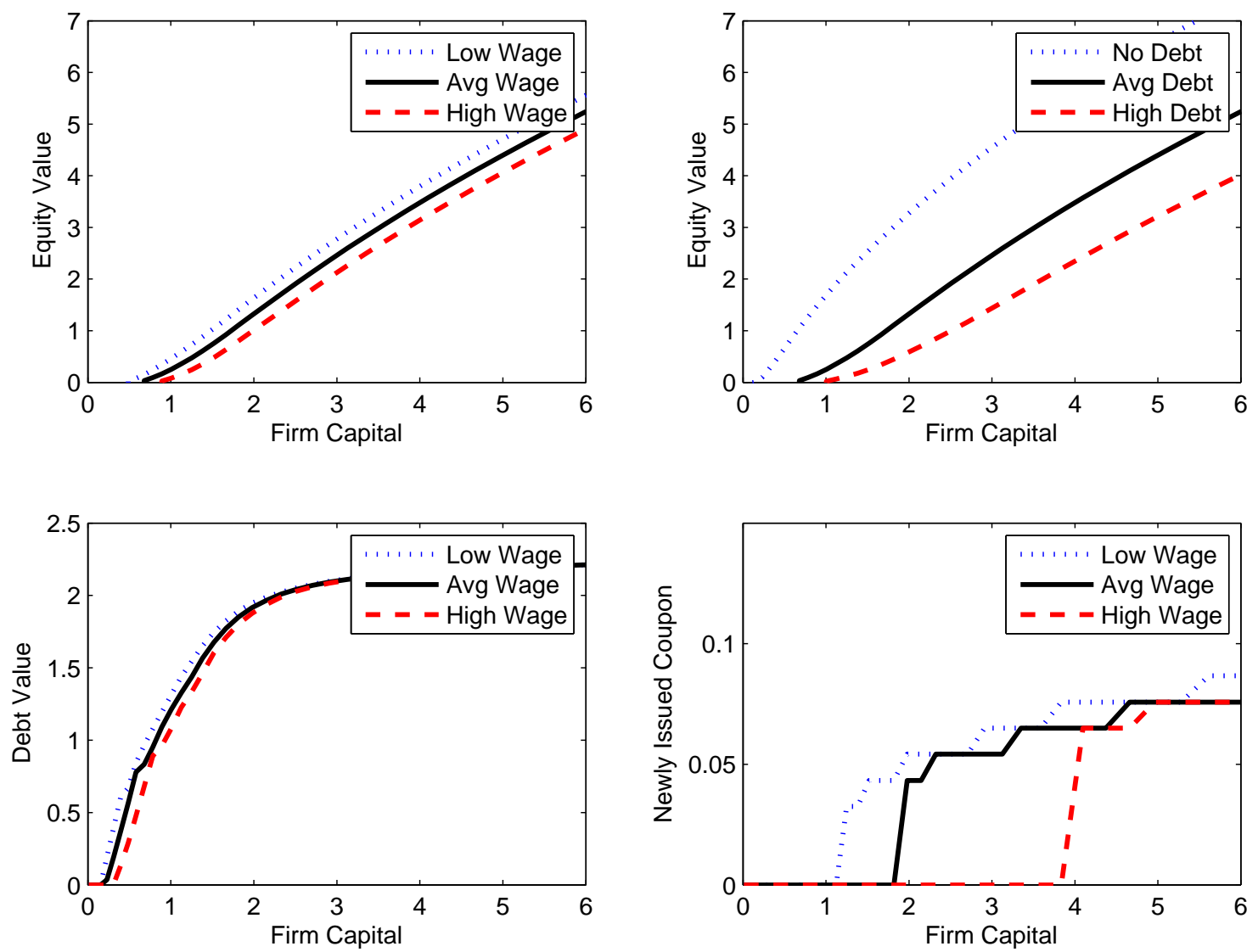

Figure A2. VAlue AND POLiCy functions.

Note: This figure plots the value of equity (top two panels), the price of debt (bottom left panel), and the policy for issuing new debt (bottom right panel) as functions of capital. The state variables $z_{t}, k_{t}$, $\bar{w}_{t-1}, Z_{t}^{i}$ and $N_{t}^{i}$ are set to their simulated means. The state variable $\bar{\kappa}_{t}^{i}$ is set to 0 , or 0.06 , or 0.10 , corresponding to no debt, average debt (Avg Debt) and high debt, respectively. The state variable $\bar{w}_{t-1}^{i}$ is set to 0.16 , or 0.20 , or 0.24 , corresponding to low wage, average wage (Avg Wage) and high wage, respectively. 

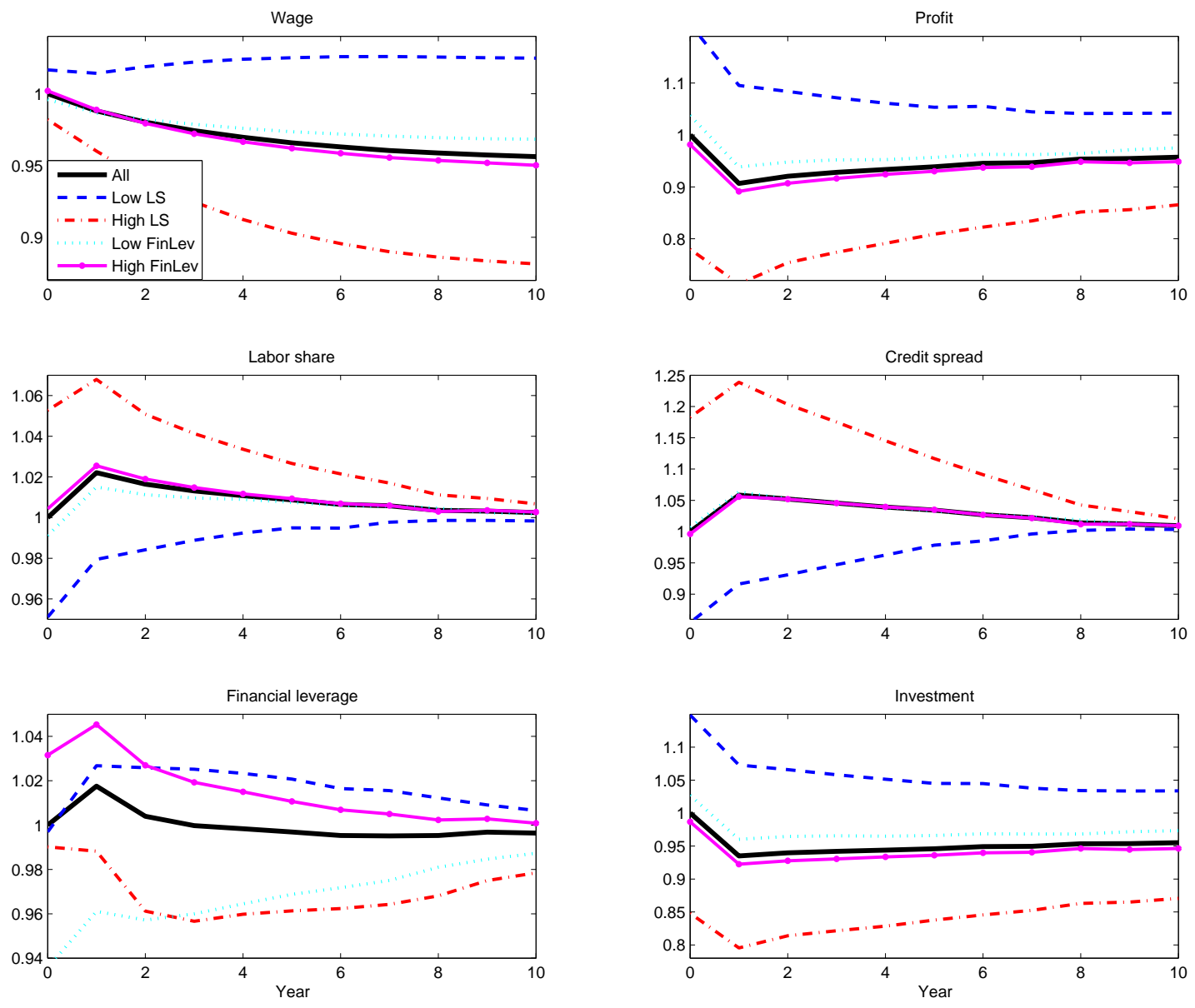

Figure A3. Impulse response functions in baseline model.

Note: This figure plots impulse response functions for wage, profit (EBITDA), labor share, financial leverage, the credit spread, and investment for a negative TFP growth realization at $t=1$ in the baseline model. This is done for an average initial conditions (All), as well as initial conditions with high or low labor share, or high or low financial leverage. High or low is defined as top or bottom 33 percent. We scale each realization $x_{t}^{i}$ where $i \in$ (All, Low LS, High LS, Low FinLev, High FinLev) by the average realization at $t=0$, that is by $x_{0}^{\text {All }}$. 

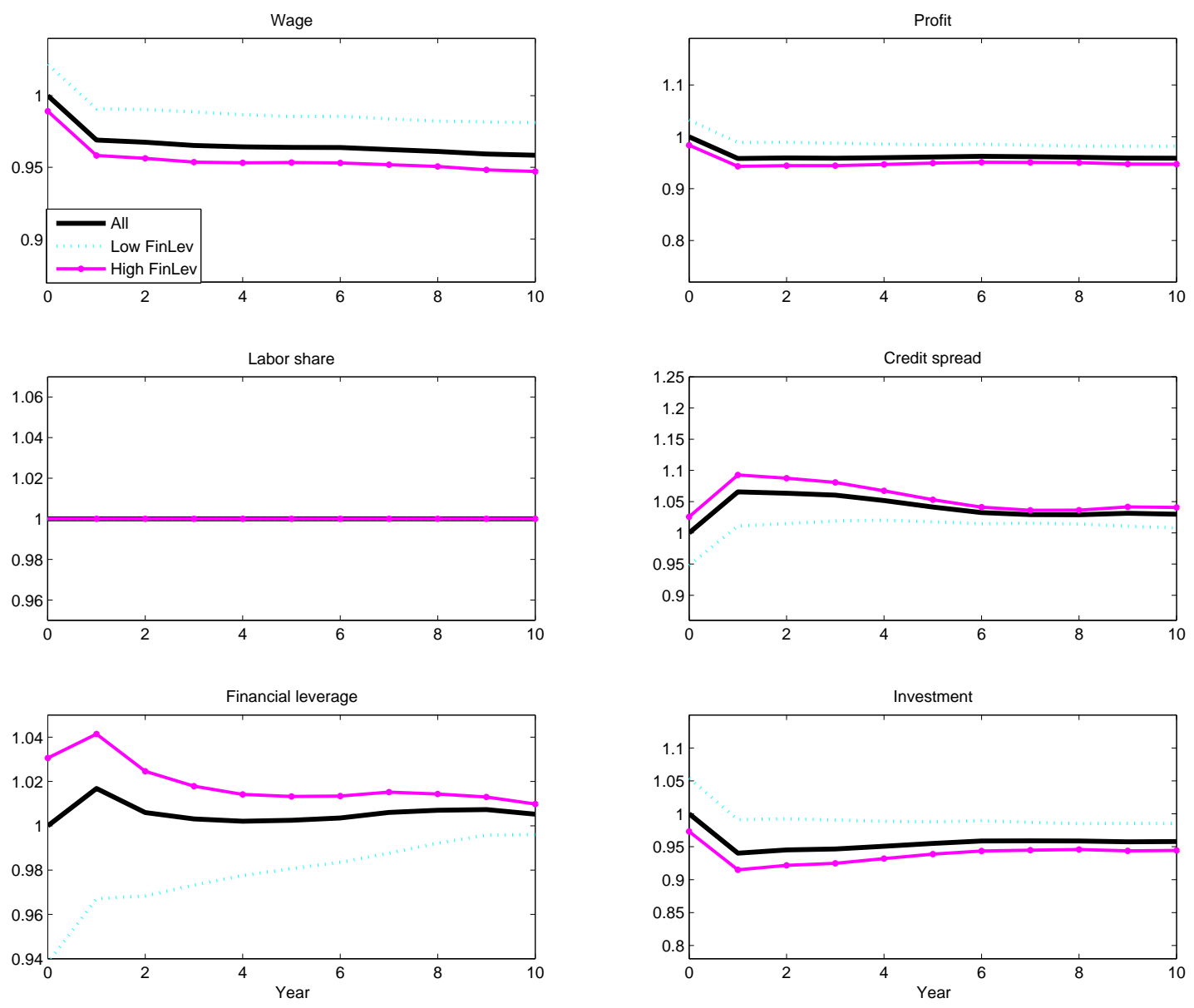

Figure A4. Impulse Response functions in Cobb-Douglas model With No Rigidity.

Note: This figure plots impulse response functions for wage, profit (EBITDA), labor share, financial leverage, the credit spread, and investment for a negative TFP growth realization at $t=1$ in the CobbDouglas model with no rigidity. This is done for an average initial conditions (All), as well as initial conditions with high or low financial leverage. High or low is defined as top or bottom 33 percent. We scale each realization $x_{t}^{i}$ where $i \in($ All, Low FinLev, High FinLev) by the average realization at $t=0$, that is by $x_{0}^{\text {All. }}$. 

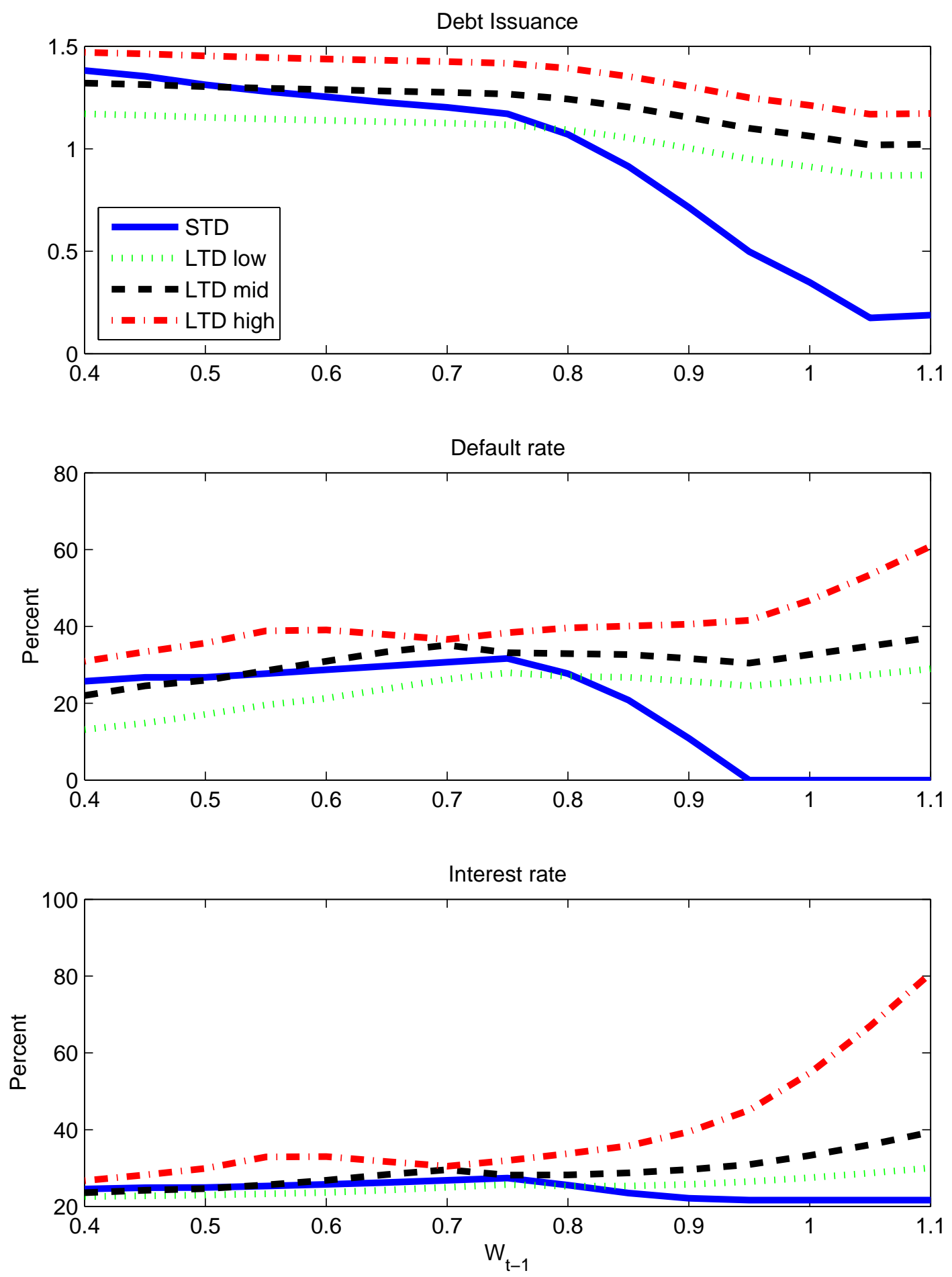

Figure A5. Policy functions. 


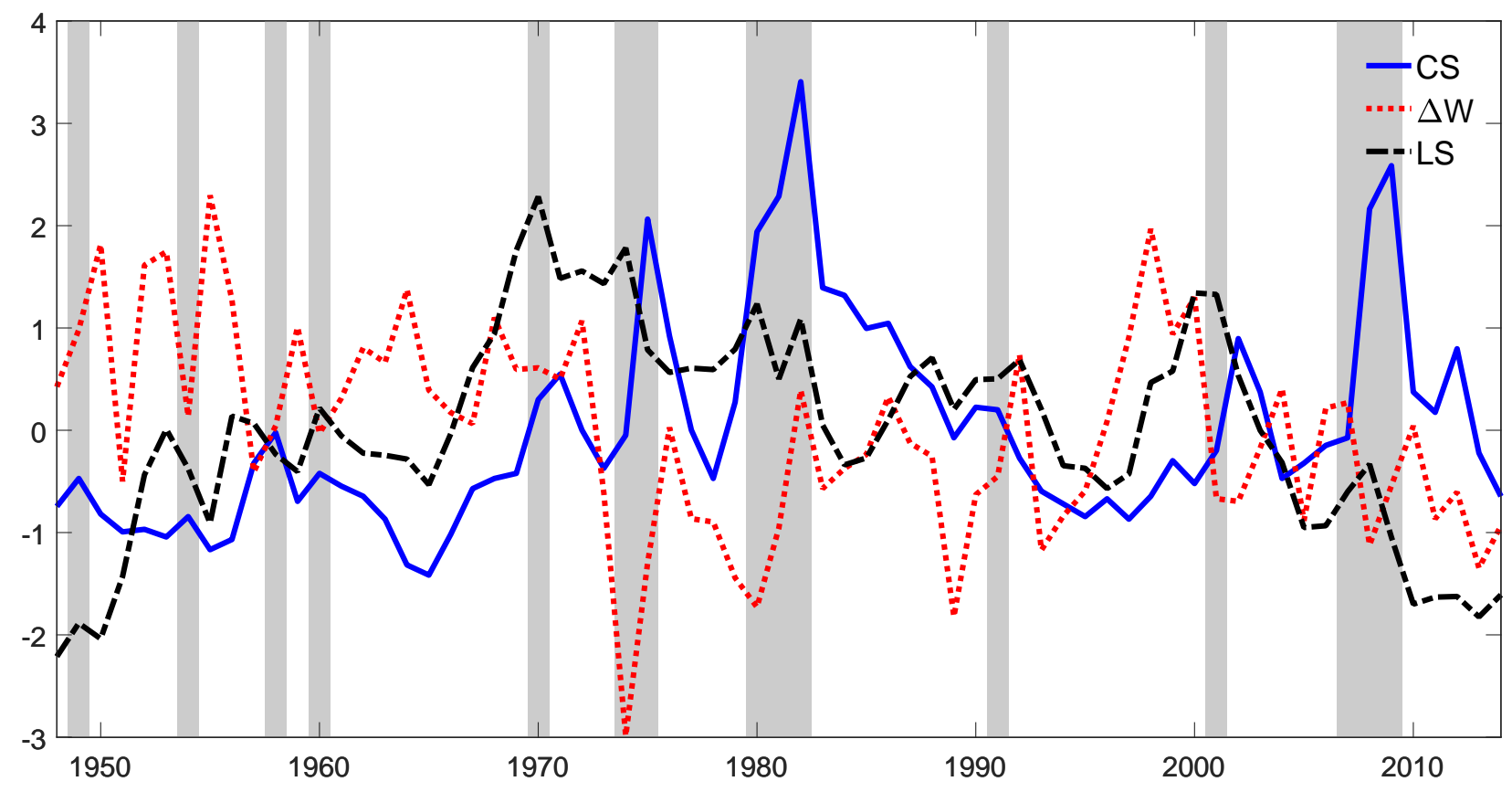

Figure A6. Labor Market Variables and Credit Spread.

Note: This figure plots the Baa-Aaa credit spread (CS), wage growth $(\Delta W)$ and labor share (LS). Wage growth is the growth rate of real wages and salaries per employee; labor share is the total compensation scaled by GDP, and credit spread is the Moody's Baa-Aaa corporate bond yield. The sample is from 1948 to 2014. The grey bars are the NBER recessions. All variables are standardized to allow for an easy comparison in one plot. 
TABle A1-Business CYClE StATistics For AdDitionAl MOdels.

\begin{tabular}{|c|c|c|c|c|c|c|}
\hline$x$ & $\frac{\sigma(x)}{\sigma(y)}$ & $\rho(x, y)$ & $\mathrm{AC}(x)$ & $\frac{\sigma(\Delta x)}{\sigma(\Delta y)}$ & $\rho(\Delta x, \Delta y)$ & $\operatorname{AC}(\Delta x)$ \\
\hline & \multicolumn{6}{|c|}{ Data } \\
\hline$y$ & 1.00 & 1.00 & 0.32 & 1.00 & 1.00 & 0.07 \\
\hline$c$ & 0.67 & 0.89 & 0.44 & 0.65 & 0.88 & 0.31 \\
\hline$i$ & 2.35 & 0.91 & 0.47 & 2.12 & 0.90 & 0.20 \\
\hline \multirow[t]{2}{*}{$w$} & 0.52 & 0.59 & 0.52 & 0.54 & 0.60 & 0.41 \\
\hline & \multicolumn{6}{|c|}{ Baseline model } \\
\hline$y$ & 1.00 & 1.00 & 0.38 & 1.00 & 1.00 & 0.28 \\
\hline$c$ & 0.69 & 0.97 & 0.42 & 0.74 & 0.97 & 0.43 \\
\hline$i$ & 2.31 & 0.97 & 0.35 & 2.18 & 0.95 & 0.14 \\
\hline$w$ & 0.40 & 0.52 & 0.69 & 0.51 & 0.59 & 0.85 \\
\hline & \multicolumn{6}{|c|}{$\eta=0$} \\
\hline$y$ & 1.00 & 1.00 & 0.39 & 1.00 & 1.00 & 0.30 \\
\hline$c$ & 0.59 & 0.96 & 0.43 & 0.67 & 0.95 & 0.50 \\
\hline$i$ & 2.51 & 0.97 & 0.38 & 2.31 & 0.95 & 0.18 \\
\hline$w$ & 0.50 & 0.59 & 0.68 & 0.59 & 0.66 & 0.82 \\
\hline & \multicolumn{6}{|c|}{$\mu=0$} \\
\hline$y$ & 1.00 & 1.00 & 0.39 & 1.00 & 1.00 & 0.29 \\
\hline$c$ & 0.70 & 0.98 & 0.42 & 0.75 & 0.98 & 0.41 \\
\hline$i$ & 2.23 & 0.97 & 0.37 & 2.10 & 0.95 & 0.17 \\
\hline$w$ & 0.71 & 0.99 & 0.42 & 0.75 & 0.98 & 0.41 \\
\hline & \multicolumn{6}{|c|}{$\eta=0, \mu=0$} \\
\hline$y$ & 1.00 & 1.00 & 0.41 & 1.00 & 1.00 & 0.33 \\
\hline$c$ & 0.62 & 0.98 & 0.45 & 0.69 & 0.96 & 0.51 \\
\hline$i$ & 2.33 & 0.98 & 0.38 & 2.17 & 0.95 & 0.19 \\
\hline$w$ & 1.00 & 1.00 & 0.41 & 1.00 & 1.00 & 0.33 \\
\hline & \multicolumn{6}{|c|}{ Short term debt } \\
\hline$y$ & 1.00 & 1.00 & 0.42 & 1.00 & 1.00 & 0.32 \\
\hline$c$ & 0.67 & 0.98 & 0.45 & 0.73 & 0.98 & 0.46 \\
\hline$i$ & 2.25 & 0.98 & 0.39 & 2.12 & 0.96 & 0.20 \\
\hline$w$ & 0.43 & 0.53 & 0.72 & 0.53 & 0.61 & 0.85 \\
\hline
\end{tabular}

Note: This table compares business cycle statistics (annual) from the data to the baseline model and to the additional models we have solved. In each panel, we list only the features different from the baseline model. The parameters of interest are $\mu$ (wage rigidity), $\eta$ (CES), $\psi$ (IES), and $\theta$ (risk aversion). 
TABle A2-Business CyCle Statistics For additional MOdels.

\begin{tabular}{ccccccc}
\hline \hline$x$ & $\frac{\sigma(x)}{\sigma(y)}$ & $\rho(x, y)$ & $\mathrm{AC}(x)$ & $\frac{\sigma(\Delta x)}{\sigma(\Delta y)}$ & $\rho(\Delta x, \Delta y)$ & $\mathrm{AC}(\Delta x)$ \\
\hline \multicolumn{5}{c}{$\psi=1.5$} \\
\hline$y$ & 1.00 & 1.00 & 0.39 & 1.00 & 1.00 & 0.29 \\
$c$ & 0.71 & 0.98 & 0.42 & 0.75 & 0.98 & 0.42 \\
$i$ & 2.24 & 0.97 & 0.37 & 2.10 & 0.95 & 0.16 \\
$w$ & 0.40 & 0.52 & 0.69 & 0.52 & 0.60 & 0.86 \\
\hline \multicolumn{5}{c}{$\psi=2.5$} \\
\hline$y$ & 1.00 & 1.00 & 0.39 & 1.00 & 1.00 & 0.29 \\
$c$ & 0.68 & 0.97 & 0.43 & 0.73 & 0.96 & 0.45 \\
$i$ & 2.40 & 0.96 & 0.36 & 2.25 & 0.94 & 0.15 \\
$w$ & 0.41 & 0.53 & 0.70 & 0.53 & 0.61 & 0.86 \\
\hline \multicolumn{5}{c}{$\theta=4$} \\
\hline$y$ & 1.00 & 1.00 & 0.39 & 1.00 & 1.00 & 0.29 \\
$c$ & 0.69 & 0.97 & 0.43 & 0.74 & 0.97 & 0.44 \\
$i$ & 2.33 & 0.96 & 0.36 & 2.18 & 0.94 & 0.15 \\
$w$ & 0.40 & 0.53 & 0.69 & 0.52 & 0.61 & 0.85 \\
\hline & \multicolumn{5}{c}{$\theta=12$} \\
\hline$y$ & 1.00 & 1.00 & 0.39 & 1.00 & 1.00 & 0.29 \\
$c$ & 0.69 & 0.98 & 0.42 & 0.74 & 0.97 & 0.43 \\
$i$ & 2.35 & 0.97 & 0.37 & 2.20 & 0.94 & 0.17 \\
$w$ & 0.40 & 0.52 & 0.70 & 0.53 & 0.60 & 0.86 \\
\hline \multicolumn{7}{c}{$\psi=0.125$} \\
\hline$y$ & 1.00 & 1.00 & 0.37 & 1.00 & 1.00 & 0.27 \\
$c$ & 1.00 & 0.97 & 0.33 & 1.02 & 0.97 & 0.22 \\
$i$ & 1.75 & 0.67 & 0.37 & 1.62 & 0.65 & 0.19 \\
$w$ & 0.29 & 0.47 & 0.69 & 0.43 & 0.54 & 0.88 \\
\hline
\end{tabular}

Note: This table compares business cycle statistics (annual) from the data to the baseline model and to the additional models we have solved. In each panel, we list only the features different from the baseline model. The parameters of interest are $\mu$ (wage rigidity), $\eta$ (CES), $\psi$ (IES), and $\theta$ (risk aversion). 
TABLE A3-MODEL COMPARISONS.

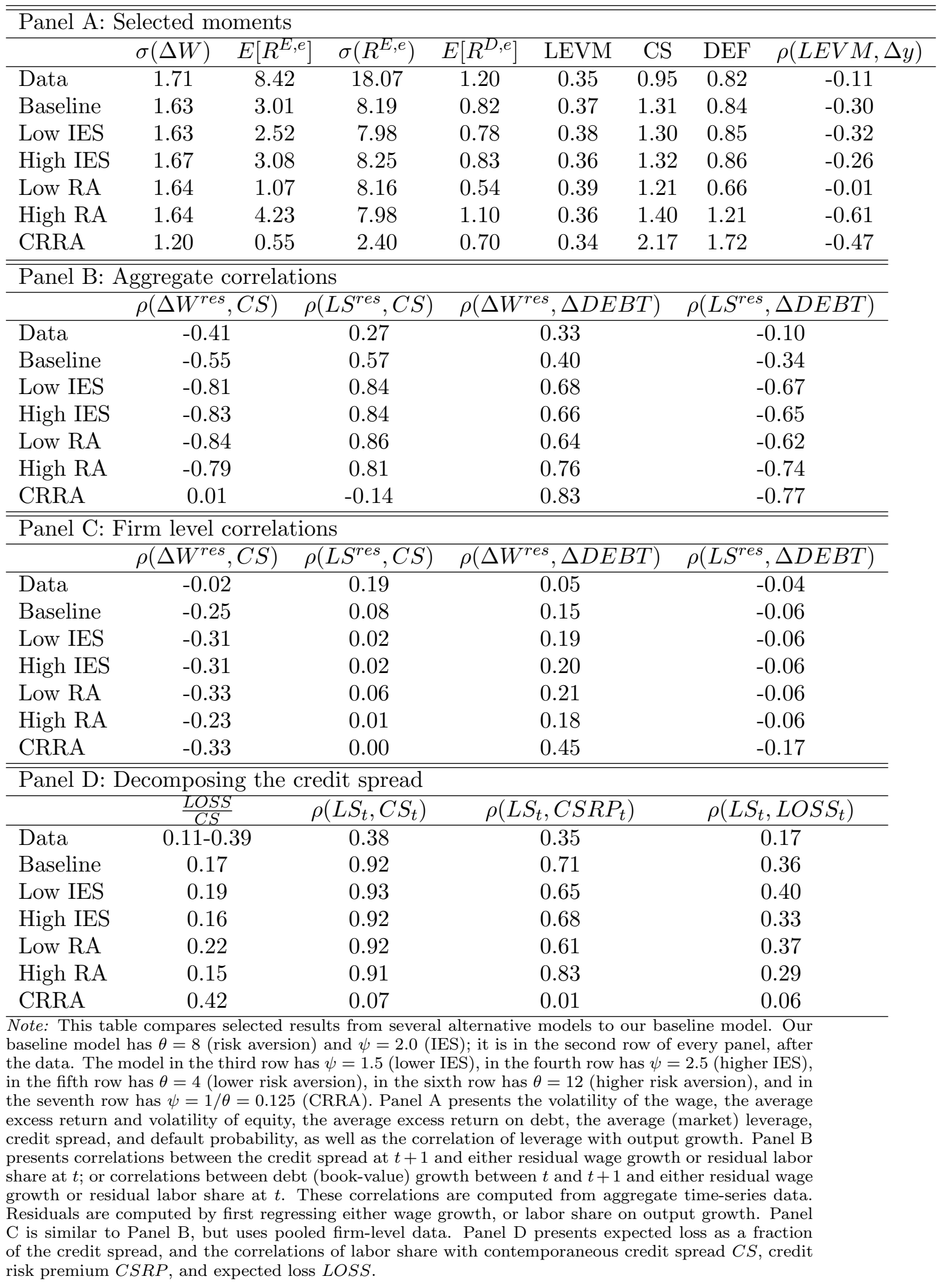


TAble A4-Descriptive Statistics.

\begin{tabular}{lrrr}
\hline & Mean & StDev & $\mathrm{AC}$ \\
\hline$\Delta \mathrm{GDP}$ & 3.22 & 2.39 & 0.15 \\
$\Delta \mathrm{W}$ & 1.50 & 1.42 & 0.46 \\
$\mathrm{LS}$ & 55.29 & 1.23 & 0.88 \\
$\Delta \mathrm{INV}$ & 4.46 & 6.31 & 0.20 \\
$\Delta \mathrm{DEBT}$ & 4.33 & 3.90 & 0.58 \\
$\mathrm{P} / \mathrm{E}$ & 18.44 & 7.51 & 0.92 \\
$\mathrm{TS}$ & 1.37 & 1.28 & 0.44 \\
FinLev & 0.35 & 0.07 & 0.85 \\
$\mathrm{MktVol}$ & 0.14 & 0.05 & 0.33 \\
$\mathrm{RF}$ & 1.57 & 2.73 & 0.56 \\
$\mathrm{DEF}$ & 0.82 & 0.98 & 0.73 \\
$\mathrm{CS}$ & 0.95 & 0.40 & 0.74 \\
$\Delta \mathrm{N}$ & 1.61 & 2.01 & 0.29 \\
$\Delta \mathrm{C}$ & 3.34 & 1.85 & 0.30 \\
$\mathrm{IS}$ & 2.96 & 1.54 & 0.98 \\
TotLev & 58.25 & 2.28 & 0.94 \\
\hline
\end{tabular}

Note: This table reports the descriptive statistics of the variables of interests. GDP growth ( $\Delta$ GDP) is the real GDP growth. Wage growth $(\Delta \mathrm{W})$ is the growth rate of real wages \& salaries per employee. Labor share (LS) is the aggregate compensation divided by GDP. Investment growth ( $\triangle \mathrm{INV})$ is the growth rate of real private nonresidential fixed investment. Employment growth $(\Delta \mathrm{N})$ is the growth rate of total employment. Consumption growth $\Delta \mathrm{C}$ uses personal consumption expenditure. The above statistics are all form BEA. Debt growth $(\triangle \mathrm{DEBT})$ is the growth rate of credit market instrument liabilities for nonfinancial corporate business sector from the Flow of Funds Table L103. P/E is the equity price to earnings ratio, and spot rate $(\mathrm{RF})$ is the real 1 year government bond yield, both from Robert Shiller's webpage. Term spread (TS) is the long-term government bond yield (10 year) minus the short-term government bond yield (1 year). Financial leverage (FinLev) is book value of nonfinancial credit instruments divided by the sum of the market value of equities and credit instruments of nonfinancial corporate business sector from Flow of Funds. Market volatility (MktVol) is the annual volatility of CRSP value-weighted market premium. The default rate (DEF) is average default rate of all rate bonds from 1948 to 2006 from Moody's. Credit spread (CS) is the Moody's Baa-Aaa corporate bond yield. Interest share (IS) is the interest paid by the non-financial corporate sector relative to GDP. Total leverage (TotalLev) is total leverage, which is defined in the text as the sum of interest share and labor share. GDP growth, wage growth, labor share, investment growth, debt growth, term spread, spot rate, default rate, credit spread, interest share and total leverage are in percentage terms. The sample is from 1948 to 2014. 
Table A5-Aggregate Credit spread, Debt Growth, and labor market VARiables.

\begin{tabular}{|c|c|c|c|c|c|c|}
\hline & $\Delta W$ & $\mathrm{LS}$ & $\mathrm{P} / \mathrm{E}$ & $\mathrm{RF}$ & $\Delta \mathrm{C}$ & $\operatorname{lag} y$ \\
\hline \multicolumn{7}{|c|}{ Panel A: Credit spread and wage growth } \\
\hline \multirow[t]{2}{*}{$\beta_{\Delta W}$} & -15.40 & -14.47 & -14.86 & -16.67 & -12.24 & -7.80 \\
\hline & $(3.71)$ & $(3.28)$ & $(3.28)$ & $(4.52)$ & $(4.23)$ & $(3.51)$ \\
\hline \multirow[t]{2}{*}{$\beta_{x}$} & & 8.52 & -0.005 & 4.63 & -4.07 & 0.62 \\
\hline & & $(2.72)$ & $(0.01)$ & $(1.77)$ & $(3.08)$ & $(0.08)$ \\
\hline adj. $R^{2}$ & 0.28 & 0.34 & 0.28 & 0.37 & 0.29 & 0.59 \\
\hline \multicolumn{7}{|c|}{ Panel B: Credit spread and labor share } \\
\hline \multirow[t]{2}{*}{$\beta_{L S}$} & 8.52 & 10.66 & 11.14 & 9.28 & 11.23 & 5.82 \\
\hline & $(2.72)$ & $(4.96)$ & $(5.45)$ & $(5.07)$ & $(2.98)$ & $(1.87)$ \\
\hline \multirow[t]{2}{*}{$\beta_{x}$} & -14.47 & & -0.01 & 2.24 & -9.84 & 0.70 \\
\hline & $(3.28)$ & & $(0.01)$ & $(2.28)$ & $(2.76)$ & $(0.06)$ \\
\hline adj. $R^{2}$ & 0.34 & 0.09 & 0.13 & 0.10 & 0.29 & 0.56 \\
\hline \multicolumn{7}{|c|}{ Panel C: Debt growth and wage growth } \\
\hline \multirow{2}{*}{$\beta_{\Delta W}$} & 1.32 & 1.28 & 1.43 & 1.23 & 0.54 & 0.76 \\
\hline & $(0.33)$ & $(0.35)$ & $(0.41)$ & $(0.28)$ & $(0.35)$ & $(0.35)$ \\
\hline \multirow[t]{2}{*}{$\beta_{x}$} & & -0.32 & -0.001 & 0.32 & 1.01 & 0.47 \\
\hline & & $(0.31)$ & $(0.001)$ & $(0.11)$ & $(0.35)$ & $(0.11)$ \\
\hline $\operatorname{adj} . R^{2}$ & 0.21 & 0.21 & 0.24 & 0.25 & 0.35 & 0.38 \\
\hline \multicolumn{7}{|c|}{ Panel D: Debt growth and labor share } \\
\hline \multirow[t]{2}{*}{$\beta_{L S}$} & -0.32 & -0.51 & -0.49 & -0.82 & -0.58 & -0.54 \\
\hline & $(0.31)$ & $(0.40)$ & $(0.40)$ & $(0.39)$ & $(0.30)$ & $(0.22)$ \\
\hline \multirow[t]{2}{*}{$\beta_{x}$} & 1.28 & & -0.000 & 0.51 & 1.26 & 0.59 \\
\hline & $(0.35)$ & & $(0.001)$ & $(0.10)$ & $(0.30)$ & $(0.07)$ \\
\hline adj. $R^{2}$ & 0.21 & 0.01 & 0.00 & 0.11 & 0.36 & 0.35 \\
\hline
\end{tabular}

Note: This table is identical to Table 1, but includes additional controls: the price earnings ratio $\mathrm{P} / \mathrm{E}$, the risk free rate $\mathrm{RF}$, consumption growth $\Delta C$, and a lag of the main variable of interest lag $y$. 
TABle A6-QuARTERLY REgRESSiONS.

\begin{tabular}{|c|c|c|c|c|c|c|c|}
\hline & $\Delta \mathrm{W}$ & LS & $\Delta \operatorname{Inv}$ & FinLev & MktVol & TS & $\Delta \mathrm{GDP}$ \\
\hline Panel A & Compe & asation & rowth a & d CS & & & \\
\hline$\beta_{\Delta W}$ & -17.23 & -16.30 & -11.51 & -12.38 & -14.71 & -18.67 & -13.50 \\
\hline & $(4.00)$ & $(4.03)$ & $(3.56)$ & $(3.29)$ & $(3.39)$ & $(4.64)$ & $(3.69)$ \\
\hline$\beta_{x}$ & & 7.12 & -3.89 & 2.97 & 0.006 & 1.46 & -5.48 \\
\hline & & $(2.70)$ & $(2.37)$ & $(0.55)$ & $(0.001)$ & $(4.45)$ & $(5.73)$ \\
\hline $\operatorname{Adj} R^{2}$ & 0.15 & 0.19 & 0.18 & 0.38 & 0.31 & 0.15 & 0.15 \\
\hline Panel B & Wage ( & ger job) & growth & nd CS & & & \\
\hline$\beta_{\Delta W}$ & -11.64 & -10.96 & -6.97 & -5.61 & -11.10 & -10.88 & -5.22 \\
\hline & $(3.18)$ & $(3.15)$ & $(2.96)$ & $(2.96)$ & $(3.19)$ & $(3.61)$ & $(3.20)$ \\
\hline$\beta_{x}$ & & 8.10 & -6.15 & 3.23 & 0.006 & 3.26 & -13.56 \\
\hline & & (3.15) & (2.31) & $(0.62)$ & $(0.001)$ & $(4.89)$ & $(5.46)$ \\
\hline $\operatorname{Adj} R^{2}$ & 0.04 & 0.09 & 0.15 & 0.31 & 0.24 & 0.03 & 0.11 \\
\hline Panel C & Labor & hare an & $\mathrm{CS}$ & & & & \\
\hline$\beta_{L S}$ & & 8.44 & 6.79 & 4.53 & 7.74 & 9.13 & 6.22 \\
\hline & & $(3.37)$ & $(3.19)$ & $(2.96)$ & $(3.10)$ & $(3.76)$ & $(3.21)$ \\
\hline$\beta_{x}$ & & & -6.19 & 3.18 & 0.006 & 6.74 & -13.38 \\
\hline & & & $(2.28)$ & $(0.59)$ & $(0.001)$ & $(5.16)$ & $(5.38)$ \\
\hline $\operatorname{Adj} R^{2}$ & & 0.06 & 0.17 & 0.32 & 0.25 & 0.05 & 0.14 \\
\hline Panel D & Compe & asation & rowth a & $\mathrm{d} \mathrm{DEE}$ & & & \\
\hline$\beta_{\Delta W}$ & 0.53 & 0.53 & 0.47 & 0.49 & 0.50 & 0.52 & 0.54 \\
\hline & $(0.09)$ & $(0.09)$ & $(0.10)$ & $(0.09)$ & $(0.09)$ & $(0.09)$ & $(0.11)$ \\
\hline$\beta_{x}$ & & -0.01 & 0.04 & -0.02 & 0.000 & -0.25 & -0.02 \\
\hline & & $(0.09)$ & $(0.06)$ & $(0.02)$ & $(0.000)$ & $(0.12)$ & $(0.11)$ \\
\hline $\operatorname{Adj} R^{2}$ & 0.16 & 0.15 & 0.16 & 0.17 & 0.17 & 0.21 & 0.15 \\
\hline Panel E & Wage ( & er job) & growth & nd $\triangle \mathrm{DE}$ & & & \\
\hline$\beta_{\Delta W}$ & 0.31 & 0.31 & 0.22 & 0.25 & 0.31 & 0.32 & 0.18 \\
\hline & $(0.10)$ & $(0.10)$ & $(0.10)$ & $(0.10)$ & $(0.10)$ & $(0.11)$ & $(0.10)$ \\
\hline$\beta_{x}$ & & -0.03 & 0.14 & -0.03 & 0.000 & -0.30 & 0.30 \\
\hline & & $(0.11)$ & $(0.05)$ & $(0.02)$ & $(0.000)$ & $(0.13)$ & $(0.10)$ \\
\hline $\operatorname{Adj} R^{2}$ & 0.03 & 0.03 & 0.09 & 0.06 & 0.06 & 0.10 & 0.07 \\
\hline Panel $\mathrm{F}$ & Labor & hare an & $\triangle \mathrm{DEB}$ & & & & \\
\hline$\beta_{L S}$ & & -0.03 & 0.04 & 0.05 & -0.02 & -0.15 & 0.03 \\
\hline & & $(0.11)$ & $(0.11)$ & $(0.12)$ & $(0.11)$ & $(0.09)$ & $(0.11)$ \\
\hline$\beta_{x}$ & & & 0.16 & -0.04 & 0.000 & -0.36 & 0.36 \\
\hline & & & $(0.06)$ & $(0.02)$ & $(0.000)$ & $(0.13)$ & $(0.10)$ \\
\hline $\operatorname{Adj} R^{2}$ & & 0.00 & 0.07 & 0.04 & 0.02 & 0.08 & 0.06 \\
\hline
\end{tabular}

Note: This table reports quarterly regressions of either credit spread at $t+1$ (CS, panels $\mathrm{A}, \mathrm{B}$ and $\mathrm{C})$ or debt growth between $t$ and $t+1(\triangle \mathrm{DEBT}$, panels $\mathrm{D}, \mathrm{E}$ and $\mathrm{F})$ on either compensation growth (panels $\mathrm{A}$ and $\mathrm{D}$ ), wage growth at $t$ (panels $\mathrm{B}$ and $\mathrm{E}$ ) or labor share at $t$ (LS, panels $\mathrm{C}$ and $\mathrm{F}$ ). CS is the Moody's Baa-Aaa corporate bond yield; DEBT is the growth rate of the sum of debt securities and loans of "Nonfinancial corporate business" from Flow of Funds Table L103.; W is the growth rate of real wages and salaries per employee; LS is the aggregate compensation divided by GDP. The controls are the growth rate of real private nonresidential fixed investment $(\Delta \mathrm{INV})$; financial leverage, measured as the book value of credit instruments (DEBT) divided by the sum of the market value of equities and credit instruments of nonfinancial corporate sector (FinLev); the long-term (10 year) government bond yield minus the short-term (1 year) government bond yield (TS); the annual volatility of CRSP value-weighted market premium (MktVol); and the real GDP growth from NIPA ( $\Delta$ GDP). Below the coefficients, we report heteroscedasticity and autocorrelation consistent (Newey and West 1987) standard errors. The sample is from 1948 to 2014 for Panels A to C; it is from 1952 to 2014 for Panels D to F; the TS result is from 1954 to 2014 . 
TAble A7-Quarterly Regressions (Additional).

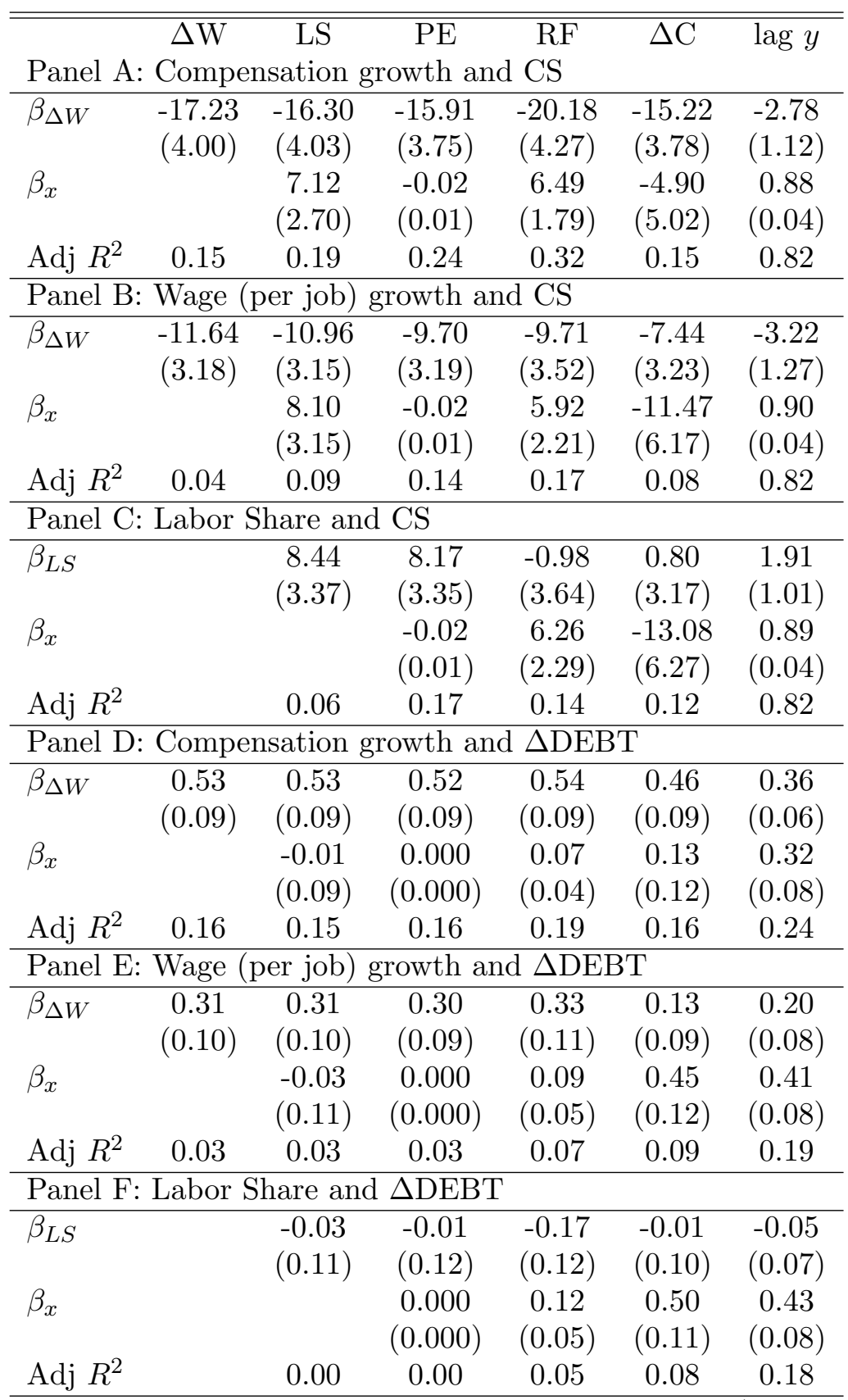

Note: This table reports quarterly regressions of either credit spread at $t+1$ (CS, panels A, B and $\mathrm{C})$ or debt growth between $t$ and $t+1$ ( $\triangle \mathrm{DEBT}$, panels $\mathrm{D}, \mathrm{E}$ and $\mathrm{F})$ on either compensation growth (panels $\mathrm{A}$ and $\mathrm{D}$ ), wage growth at $t$ (panels $\mathrm{B}$ and $\mathrm{E}$ ) or labor share at $t$ (LS, panels $\mathrm{C}$ and $\mathrm{F}$ ). CS is the Moody's Baa-Aaa corporate bond yield; DEBT is the growth rate of the sum of debt securities and loans of "Nonfinancial corporate business" from Flow of Funds Table L103; W is the growth rate of real wages and salaries per employee; LS is the aggregate compensation divided by GDP. The controls are the equity price to earnings ratio from Robert Shiller's website $(\mathrm{P} / \mathrm{E})$; the real 1 year government bond yield from St Lious Fed; the real consumption (personal consumption expenditures) growth from NIPA $(\Delta \mathrm{C})$; and the lagged value of the dependent variable (lag y). Below the coefficients, we report heteroscedasticity and autocorrelation consistent (Newey and West 1987) standard errors. The sample is from 1948 to 2014 for Panels A to C; it is from 1952 to 2014 for Panels D to F; the RF result is from 1954 to 2014. 
TABle A8-AnNual observations With NON-Missing LABOR EXPENSES AND EDF.

\begin{tabular}{|c|c|c|c|c|c|c|c|c|}
\hline & & & & & & & $\begin{array}{l}\text { Within } \\
\text { Country }\end{array}$ & $\begin{array}{c}\text { For all } \\
\text { Countries }\end{array}$ \\
\hline Country & $\begin{array}{l}\text { Start } \\
\text { Year }\end{array}$ & $\begin{array}{l}\text { End } \\
\text { Year }\end{array}$ & $\begin{array}{l}\text { All } \\
\text { Obs }\end{array}$ & $\begin{array}{l}\text { \# Obs } \\
\text { w XLR }\end{array}$ & $\begin{array}{l}\text { \# Obs } \\
\text { w EDF }\end{array}$ & $\begin{array}{c}\text { \# Obs } \\
\text { XLR/EDF }\end{array}$ & $\begin{array}{l}\text { \% of obs w/ } \\
\text { XLR/EDF }\end{array}$ & $\begin{array}{l}\text { \% of obs w/ } \\
\text { XLR/EDF }\end{array}$ \\
\hline \multicolumn{9}{|l|}{ Region: Europe } \\
\hline Austria & 1992 & 2011 & 1425 & 1318 & 981 & 914 & 64.14 & 0.99 \\
\hline Belgium & 1992 & 2011 & 1769 & 1597 & 1224 & 1118 & 63.20 & 1.21 \\
\hline Denmark & 1992 & 2011 & 2244 & 2048 & 1457 & 1347 & 60.03 & 1.46 \\
\hline Finland & 1992 & 2011 & 1995 & 1897 & 1544 & 1474 & 73.88 & 1.59 \\
\hline France & 1992 & 2011 & 10855 & 10055 & 8105 & 7597 & 69.99 & 8.21 \\
\hline Germany & 1992 & 2011 & 11151 & 10005 & 7200 & 6612 & 59.30 & 7.14 \\
\hline Greece & 1994 & 2011 & 2443 & 1443 & 1724 & 1002 & 41.02 & 1.08 \\
\hline Italy & 1992 & 2011 & 3631 & 3425 & 2584 & 2448 & 67.42 & 2.64 \\
\hline Netherlands & 1992 & 2011 & 2756 & 2492 & 2085 & 1919 & 69.63 & 2.07 \\
\hline Norway & 1992 & 2011 & 3021 & 2607 & 1900 & 1672 & 55.35 & 1.81 \\
\hline Poland & 1994 & 2011 & 3722 & 2699 & 1457 & 1072 & 28.80 & 1.16 \\
\hline Portugal & 1992 & 2011 & 857 & 771 & 643 & 585 & 68.26 & 0.63 \\
\hline Spain & 1992 & 2011 & 2216 & 2149 & 1674 & 1657 & 74.77 & 1.79 \\
\hline Sweden & 1992 & 2011 & 5712 & 4798 & 3041 & 2644 & 46.29 & 2.86 \\
\hline Switzerland & 1992 & 2011 & 3485 & 3176 & 2378 & 2195 & 62.98 & 2.37 \\
\hline United Kingdom & 1992 & 2011 & 26546 & 21034 & 18954 & 16223 & 61.11 & 17.53 \\
\hline \multicolumn{9}{|c|}{ Region: North America } \\
\hline Canada & 1992 & 2011 & 23575 & 3228 & 11908 & 1769 & 7.50 & 1.91 \\
\hline United States & 1992 & 2011 & 135632 & 9588 & 69610 & 4877 & 3.60 & 5.27 \\
\hline \multicolumn{9}{|l|}{ Region: Japan } \\
\hline Japan & 1992 & 2011 & 50011 & 2 & 42403 & & 0.00 & 0.00 \\
\hline \multicolumn{9}{|c|}{ Region: Asia Pacific (ex. Japan) } \\
\hline Australia & 1992 & 2011 & 19885 & 11285 & 12018 & 7472 & 37.58 & 8.07 \\
\hline China & 1992 & 2011 & 27448 & 1210 & 10755 & 594 & 2.16 & 0.64 \\
\hline Hong Kong & 1992 & 2011 & 3468 & 2363 & 1812 & 1244 & 35.87 & 1.34 \\
\hline India & 1992 & 2011 & 29938 & 26949 & 6603 & 6283 & 20.99 & 6.79 \\
\hline Indonesia & 1992 & 2011 & 4017 & 2705 & 2377 & 1607 & 40.00 & 1.74 \\
\hline Malaysia & 1992 & 2011 & 12457 & 7986 & 9084 & 6777 & 54.40 & 7.32 \\
\hline New Zealand & 1992 & 2011 & 1633 & 563 & 1029 & 435 & 26.64 & 0.47 \\
\hline Philippines & 1992 & 2011 & 2198 & 1296 & 995 & 651 & 29.62 & 0.70 \\
\hline Singapore & 1992 & 2011 & 7903 & 5210 & 5211 & 3779 & 47.82 & 4.08 \\
\hline S. Korea & 1993 & 2011 & 8701 & 75 & 5916 & 49 & 0.56 & 0.05 \\
\hline Taiwan & 1992 & 2011 & 14520 & 214 & 10868 & 106 & 0.73 & 0.11 \\
\hline Thailand & 1992 & 2011 & 5749 & 3171 & 3240 & 1978 & 34.41 & 2.14 \\
\hline \multicolumn{9}{|c|}{ Region: Other America (ex. Canada and U.S.) } \\
\hline Argentina & 1992 & 2011 & 934 & 352 & 667 & 266 & 28.48 & 0.29 \\
\hline Brazil & 1992 & 2011 & 4558 & 2039 & 671 & 414 & 9.08 & 0.45 \\
\hline Chile & 1992 & 2011 & 2171 & 346 & 1303 & 231 & 10.64 & 0.25 \\
\hline Mexico & 1992 & 2011 & 1674 & 282 & 993 & 145 & 8.66 & 0.16 \\
\hline \multicolumn{9}{|c|}{ Region: Middle East } \\
\hline Israel & 1992 & 2011 & 2975 & 2058 & 1008 & 735 & 24.71 & 0.79 \\
\hline Pakistan & 1994 & 2011 & 2814 & 2033 & 993 & 738 & 26.23 & 0.80 \\
\hline Turkey & 1992 & 2011 & 1905 & 854 & 1443 & 670 & 35.17 & 0.72 \\
\hline \multicolumn{9}{|l|}{ Region: Africa } \\
\hline South Africa & 1992 & 2011 & 3761 & 1893 & 2330 & 1254 & 33.34 & 1.35 \\
\hline Total & & & 451755 & 157216 & 260188 & 92553 & & \\
\hline
\end{tabular}

Note: This table reports the number of annual (firm-year) observations for each individual country. The number of annual observations with non-missing labor expenses (Compustat variable XLR) and the EDF is reported in the column titled "\# Obs w XLR/EDF". The percentage of observations with non-missing labor expenses and EDF is reported for each country (column titled "Within country \% of obs w XLR/EDF"). The last column titled "For all countries \% of obs w XLR/EDF" presents the percentage of observations with non-missing labor expenses and EDF contributed by each country to the final sample of all observations with non-missing labor expenses, and EDF (total \# of obs = 92553). 
TABle A9-Annual obSERVATIONS With NON-MiSSING LABOR EXPENSES AND CDS.

\begin{tabular}{|c|c|c|c|c|c|c|c|}
\hline Year & \# Obs. & $\%$ Obs & Country & \# Obs & $\% \mathrm{Obs}$ & Mean & St.D. \\
\hline 2000 & 101 & 2.66 & Finland & 84 & 2.21 & 1.61 & 1.50 \\
\hline 2001 & 129 & 3.39 & France & 409 & 10.76 & 1.71 & 2.29 \\
\hline 2002 & 162 & 4.26 & Germany & 323 & 8.50 & 1.51 & 1.83 \\
\hline 2003 & 186 & 4.89 & Italy & 141 & 3.71 & 2.95 & 7.01 \\
\hline 2004 & 214 & 5.63 & Netherlands & 103 & 2.71 & 1.27 & 1.20 \\
\hline 2005 & 230 & 6.05 & Spain & 118 & 3.10 & 2.14 & 2.54 \\
\hline 2006 & 255 & 6.71 & Sweden & 162 & 4.26 & 1.06 & 1.32 \\
\hline 2007 & 319 & 8.39 & Switzerland & 91 & 2.39 & 0.81 & 0.65 \\
\hline 2008 & 363 & 9.55 & United Kingdom & 551 & 14.50 & 1.41 & 3.09 \\
\hline 2009 & 362 & 9.52 & Canada & 70 & 1.84 & 2.63 & 5.89 \\
\hline 2010 & 378 & 9.94 & United States & 558 & 14.68 & 3.49 & 7.71 \\
\hline 2011 & 372 & 9.79 & Australia & 183 & 4.81 & 1.70 & 1.86 \\
\hline 2012 & 372 & 9.79 & Hong Kong & 113 & 2.97 & 1.33 & 1.52 \\
\hline \multirow[t]{5}{*}{2013} & 358 & 9.42 & India & 252 & 6.63 & 6.59 & 15.27 \\
\hline & & & Malaysia & 71 & 1.87 & 1.04 & 0.67 \\
\hline & & & Brazil & 77 & 2.03 & 3.13 & 2.61 \\
\hline & & & South Africa & 65 & 1.71 & 3.49 & 3.25 \\
\hline & & & Other & 430 & 11.31 & 3.72 & 8.38 \\
\hline Total & 3801 & 100 & & 3801 & 100 & 2.51 & 6.31 \\
\hline
\end{tabular}


TABle A10-Summary Statistics on LABOR EXPEnses AND EDF.

\begin{tabular}{|c|c|c|c|c|c|c|c|c|}
\hline & \multicolumn{2}{|c|}{$E D F$} & \multicolumn{3}{|c|}{$\triangle X L R$} & \multicolumn{3}{|c|}{$L S$} \\
\hline Country & Mean & St.D. & Mean $(\mathrm{EW})$ & Mean (VW) & St.D. & Mean (EW) & Mean (VW) & St.D. \\
\hline \multicolumn{9}{|c|}{ Region: Europe } \\
\hline Austria & 1.57 & 3.90 & 0.06 & 0.02 & 0.39 & 0.73 & 0.73 & 0.38 \\
\hline Belgium & 1.25 & 3.14 & 0.10 & 0.06 & 0.50 & 0.65 & 0.72 & 0.41 \\
\hline Denmark & 1.34 & 3.45 & 0.11 & 0.14 & 0.43 & 0.75 & 0.72 & 0.50 \\
\hline Finland & 1.03 & 2.79 & 0.10 & 0.12 & 0.43 & 0.71 & 0.65 & 0.34 \\
\hline France & 1.94 & 4.15 & 0.11 & 0.10 & 0.42 & 0.73 & 0.70 & 0.43 \\
\hline Germany & 2.47 & 5.44 & 0.09 & 0.08 & 0.46 & 0.78 & 0.70 & 0.53 \\
\hline Greece & 3.71 & 6.09 & 0.05 & 0.19 & 0.56 & 0.67 & 0.83 & 0.56 \\
\hline Italy & 1.39 & 3.22 & 0.08 & 0.02 & 0.42 & 0.65 & 0.75 & 0.45 \\
\hline Netherlands & 1.30 & 3.72 & 0.08 & 0.12 & 0.47 & 0.70 & 0.74 & 0.38 \\
\hline Norway & 2.50 & 5.50 & 0.17 & 0.13 & 0.52 & 0.78 & 0.71 & 0.68 \\
\hline Poland & 2.40 & 4.80 & 0.08 & 0.04 & 0.38 & 0.69 & 0.52 & 0.51 \\
\hline Portugal & 2.27 & 4.52 & 0.08 & 0.12 & 0.28 & 0.58 & 0.71 & 0.34 \\
\hline Spain & 0.85 & 2.38 & 0.09 & 0.07 & 0.25 & 0.60 & 0.72 & 0.39 \\
\hline Sweden & 1.73 & 4.18 & 0.15 & 0.08 & 0.42 & 0.92 & 0.79 & 0.69 \\
\hline Switzerland & 0.82 & 2.74 & 0.09 & 0.16 & 0.43 & 0.67 & 0.64 & 0.36 \\
\hline United Kingdom & 2.07 & 4.50 & 0.16 & 0.20 & 0.64 & 0.67 & 0.53 & 0.59 \\
\hline \multicolumn{9}{|c|}{ Region: North America } \\
\hline Canada & 4.14 & 7.61 & 0.15 & 0.05 & 0.64 & 0.72 & 0.59 & 0.75 \\
\hline United States & 2.77 & 6.12 & 0.10 & 0.05 & 0.32 & 0.73 & 0.70 & 0.59 \\
\hline \multicolumn{9}{|l|}{ Region: Japan } \\
\hline Japan & 2.31 & 4.22 & 0.13 & 0.07 & & 0.51 & 0.51 & 0.03 \\
\hline \multicolumn{9}{|c|}{ Region: Asia Pacific (ex. Japan) } \\
\hline Australia & 2.50 & 5.15 & 0.27 & 0.32 & 0.79 & 0.82 & 0.62 & 0.96 \\
\hline China & 0.87 & 1.74 & 0.24 & 0.23 & 0.40 & 0.46 & 0.59 & 0.49 \\
\hline Hong Kong & 1.79 & 3.73 & 0.21 & 0.25 & 0.57 & 0.53 & 0.52 & 0.62 \\
\hline India & 4.00 & 6.30 & 0.13 & 0.24 & 0.49 & 0.43 & 0.53 & 0.52 \\
\hline Indonesia & 6.71 & 9.50 & 0.14 & 0.22 & 0.57 & 0.42 & 0.50 & 0.49 \\
\hline Malaysia & 2.98 & 5.43 & 0.10 & 0.17 & 0.39 & 0.56 & 0.47 & 0.59 \\
\hline New Zealand & 1.63 & 4.25 & 0.18 & 0.21 & 0.58 & 0.60 & 0.56 & 0.52 \\
\hline Philippines & 5.67 & 8.98 & 0.08 & 0.23 & 0.64 & 0.46 & 0.48 & 0.56 \\
\hline Singapore & 2.59 & 4.41 & 0.13 & 0.23 & 0.53 & 0.64 & 0.41 & 0.62 \\
\hline S. Korea & 4.15 & 6.51 & 0.12 & 0.04 & 0.41 & 0.40 & 0.40 & 0.59 \\
\hline Taiwan & 1.74 & 3.29 & 0.21 & 0.09 & 0.40 & 0.43 & 0.56 & 0.66 \\
\hline Thailand & 3.53 & 6.76 & 0.12 & 0.20 & 0.35 & 0.56 & 0.50 & 0.55 \\
\hline \multicolumn{9}{|c|}{ Region: Other America (ex. Canada and U.S.) } \\
\hline Argentina & 4.31 & 7.15 & 0.16 & 0.24 & 0.42 & 0.47 & 0.48 & 0.35 \\
\hline Brazil & 3.68 & 7.06 & 0.19 & 0.35 & 0.69 & 0.42 & 0.85 & 0.54 \\
\hline Chile & 1.55 & 4.17 & 0.19 & 0.17 & 0.54 & 0.45 & 0.63 & 0.37 \\
\hline Mexico & 2.91 & 6.12 & 0.05 & 0.12 & 0.84 & 0.16 & 0.75 & 0.28 \\
\hline \multicolumn{9}{|c|}{ Region: Middle East } \\
\hline Israel & 1.92 & 4.13 & 0.16 & 0.31 & 0.77 & 0.53 & 0.57 & 0.52 \\
\hline Pakistan & 5.84 & 8.93 & 0.08 & 0.10 & 0.53 & 0.36 & 0.42 & 0.47 \\
\hline Turkey & 1.68 & 2.81 & 0.14 & 0.07 & 0.53 & 0.47 & 0.49 & 0.49 \\
\hline \multicolumn{9}{|l|}{ Region: Africa } \\
\hline South Africa & 3.61 & 6.97 & 0.19 & 0.26 & 0.64 & 0.58 & 0.62 & 0.48 \\
\hline Total & 2.56 & 5.39 & 0.13 & 0.13 & 0.53 & 0.62 & 0.65 & 0.58 \\
\hline
\end{tabular}

Note: This table reports the summary statistics on EDF, labor expenses growth, and labor share. We define labor expenses growth as $\Delta X L R=\left(X L R_{t}-X L R_{t-1}\right) /\left[0.5 \times\left(X L R_{t}+X L R_{t-1}\right)\right]$ and labor share as $L S_{t}=X L R_{t} /\left(X L R_{t}+E B I T D A_{t}\right)$ for year $t$. We report the mean and standard deviation of these variables within each country; we also report the same summary statistics for all countries in the last row "Total". 


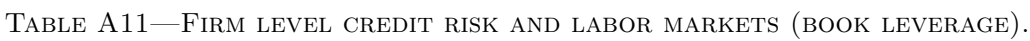

\begin{tabular}{|c|c|c|c|c|c|c|c|c|}
\hline \multirow[b]{2}{*}{$\Delta \mathrm{XLR}$} & \multicolumn{4}{|c|}{$\overline{\mathrm{EDF}}$} & \multicolumn{4}{|c|}{$\overline{\Delta \mathrm{DEBT}}$} \\
\hline & $\begin{array}{l}-0.447 \\
(0.062)\end{array}$ & $\begin{array}{l}-0.076 \\
(0.058)\end{array}$ & & & $\begin{array}{c}0.058 \\
(0.010)\end{array}$ & $\begin{array}{l}-0.007 \\
(0.007)\end{array}$ & & \\
\hline LS & & & $\begin{array}{c}0.705 \\
(0.078)\end{array}$ & $\begin{array}{c}0.550 \\
(0.082)\end{array}$ & & & $\begin{array}{l}-0.012 \\
(0.005)\end{array}$ & $\begin{array}{l}-0.024 \\
(0.005)\end{array}$ \\
\hline$\Delta \mathrm{XLR} \times \mu$ & & $\begin{array}{l}-0.212 \\
(0.042)\end{array}$ & & & & $\begin{array}{c}0.034 \\
(0.003)\end{array}$ & & \\
\hline $\mathrm{LS} \times \mu$ & & & & $\begin{array}{c}0.076 \\
(0.011)\end{array}$ & & & & $\begin{array}{c}0.004 \\
(0.002)\end{array}$ \\
\hline$\mu$ & & $\begin{array}{l}-0.049 \\
(0.011)\end{array}$ & & $\begin{array}{l}-0.101 \\
(0.013)\end{array}$ & & $\begin{array}{l}-0.006 \\
(0.001)\end{array}$ & & $\begin{array}{l}-0.006 \\
(0.001)\end{array}$ \\
\hline LEV & $\begin{array}{c}4.749 \\
(1.172)\end{array}$ & $\begin{array}{c}4.657 \\
(1.171)\end{array}$ & $\begin{array}{c}4.046 \\
(1.025)\end{array}$ & $\begin{array}{c}4.017 \\
(0.998)\end{array}$ & $\begin{array}{l}-0.493 \\
(0.057)\end{array}$ & $\begin{array}{l}-0.492 \\
(0.056)\end{array}$ & $\begin{array}{l}-0.473 \\
(0.052)\end{array}$ & $\begin{array}{l}-0.473 \\
(0.053)\end{array}$ \\
\hline$\sigma$ & $\begin{array}{c}1.485 \\
(0.219)\end{array}$ & $\begin{array}{l}1.448 \\
(0.215)\end{array}$ & $\begin{array}{c}1.382 \\
(0.221)\end{array}$ & $\begin{array}{l}1.339 \\
(0.234)\end{array}$ & $\begin{array}{l}-0.011 \\
(0.003)\end{array}$ & $\begin{array}{l}-0.011 \\
(0.003)\end{array}$ & $\begin{array}{l}-0.009 \\
(0.002)\end{array}$ & $\begin{array}{l}-0.009 \\
(0.003)\end{array}$ \\
\hline WCTA & $\begin{array}{l}-2.576 \\
(0.359)\end{array}$ & $\begin{array}{l}-2.675 \\
(0.381)\end{array}$ & $\begin{array}{l}-2.223 \\
(0.345)\end{array}$ & $\begin{array}{l}-2.252 \\
(0.344)\end{array}$ & $\begin{array}{l}-0.035 \\
(0.039)\end{array}$ & $\begin{array}{l}-0.036 \\
(0.038)\end{array}$ & $\begin{array}{l}-0.055 \\
(0.045)\end{array}$ & $\begin{array}{l}-0.057 \\
(0.047)\end{array}$ \\
\hline RETA & $\begin{array}{l}-0.144 \\
(0.203)\end{array}$ & $\begin{array}{l}-0.157 \\
(0.185)\end{array}$ & $\begin{array}{c}-0.546 \\
(0.388)\end{array}$ & $\begin{array}{l}-0.618 \\
(0.374)\end{array}$ & $\begin{array}{l}-0.019 \\
(0.009)\end{array}$ & $\begin{array}{l}-0.019 \\
(0.009)\end{array}$ & $\begin{array}{l}-0.016 \\
(0.006)\end{array}$ & $\begin{array}{l}-0.017 \\
(0.006)\end{array}$ \\
\hline EBITTA & $\begin{array}{l}-2.830 \\
(0.803)\end{array}$ & $\begin{array}{l}-2.716 \\
(0.851)\end{array}$ & $\begin{array}{l}-4.351 \\
(0.912)\end{array}$ & $\begin{array}{l}-3.880 \\
(0.860)\end{array}$ & $\begin{array}{c}0.120 \\
(0.059)\end{array}$ & $\begin{array}{c}0.128 \\
(0.063)\end{array}$ & $\begin{array}{c}0.187 \\
(0.114)\end{array}$ & $\begin{array}{c}0.217 \\
(0.122)\end{array}$ \\
\hline SaleGr & $\begin{array}{l}-0.643 \\
(0.074)\end{array}$ & $\begin{array}{l}-0.634 \\
(0.084)\end{array}$ & $\begin{array}{c}-0.864 \\
(0.096)\end{array}$ & $\begin{array}{l}-0.920 \\
(0.113)\end{array}$ & $\begin{array}{c}0.081 \\
(0.008)\end{array}$ & $\begin{array}{c}0.065 \\
(0.005)\end{array}$ & $\begin{array}{c}0.123 \\
(0.010)\end{array}$ & $\begin{array}{c}0.115 \\
(0.007)\end{array}$ \\
\hline NITA & $\begin{array}{l}-0.509 \\
(0.391)\end{array}$ & $\begin{array}{l}-0.570 \\
(0.346)\end{array}$ & $\begin{array}{l}-2.294 \\
(0.861)\end{array}$ & $\begin{array}{l}-2.263 \\
(0.903)\end{array}$ & $\begin{array}{c}-0.006 \\
(0.027)\end{array}$ & $\begin{array}{l}-0.003 \\
(0.026)\end{array}$ & $\begin{array}{c}0.068 \\
(0.027)\end{array}$ & $\begin{array}{c}0.067 \\
(0.029)\end{array}$ \\
\hline CACL & $\begin{array}{c}0.008 \\
(0.020)\end{array}$ & $\begin{array}{c}0.009 \\
(0.020)\end{array}$ & $\begin{array}{c}0.005 \\
(0.022)\end{array}$ & $\begin{array}{c}0.008 \\
(0.025)\end{array}$ & $\begin{array}{c}0.002 \\
(0.002)\end{array}$ & $\begin{array}{c}0.002 \\
(0.002)\end{array}$ & $\begin{array}{c}0.003 \\
(0.002)\end{array}$ & $\begin{array}{c}0.003 \\
(0.002)\end{array}$ \\
\hline Invest & $\begin{array}{c}0.021 \\
(0.004)\end{array}$ & $\begin{array}{c}0.019 \\
(0.003)\end{array}$ & $\begin{array}{c}0.019 \\
(0.004)\end{array}$ & $\begin{array}{l}0.020 \\
(0.005)\end{array}$ & $\begin{array}{c}0.003 \\
(0.002)\end{array}$ & $\begin{array}{c}0.002 \\
(0.002)\end{array}$ & $\begin{array}{c}0.004 \\
(0.002)\end{array}$ & $\begin{array}{c}0.003 \\
(0.002)\end{array}$ \\
\hline$R_{e x c}$ & $\begin{array}{l}-0.360 \\
(0.541)\end{array}$ & $\begin{array}{l}-0.321 \\
(0.562)\end{array}$ & $\begin{array}{l}-0.338 \\
(0.571)\end{array}$ & $\begin{array}{l}-0.254 \\
(0.534)\end{array}$ & $\begin{array}{c}0.033 \\
(0.022)\end{array}$ & $\begin{array}{c}0.038 \\
(0.023)\end{array}$ & $\begin{array}{c}0.030 \\
(0.018)\end{array}$ & $\begin{array}{c}0.033 \\
(0.017)\end{array}$ \\
\hline RSIZE & $\begin{array}{c}0.501 \\
(0.535)\end{array}$ & $\begin{array}{c}0.491 \\
(0.543)\end{array}$ & $\begin{array}{c}0.368 \\
(0.441)\end{array}$ & $\begin{array}{c}0.368 \\
(0.445)\end{array}$ & $\begin{array}{l}-0.003 \\
(0.003)\end{array}$ & $\begin{array}{l}-0.003 \\
(0.003)\end{array}$ & $\begin{array}{l}-0.004 \\
(0.003)\end{array}$ & $\begin{array}{l}-0.004 \\
(0.003)\end{array}$ \\
\hline$R_{m}$ & $\begin{array}{c}9.356 \\
(2.749)\end{array}$ & $\begin{array}{c}9.413 \\
(2.703)\end{array}$ & $\begin{array}{c}7.776 \\
(2.264)\end{array}$ & $\begin{array}{c}7.754 \\
(2.260)\end{array}$ & $\begin{array}{l}-0.230 \\
(0.059)\end{array}$ & $\begin{array}{l}-0.227 \\
(0.060)\end{array}$ & $\begin{array}{l}-0.197 \\
(0.068)\end{array}$ & $\begin{array}{l}-0.202 \\
(0.068)\end{array}$ \\
\hline MCAP & $\begin{array}{l}-0.996 \\
(0.614)\end{array}$ & $\begin{array}{l}-0.987 \\
(0.621)\end{array}$ & $\begin{array}{l}-0.803 \\
(0.507)\end{array}$ & $\begin{array}{l}-0.802 \\
(0.510)\end{array}$ & $\begin{array}{c}0.013 \\
(0.002)\end{array}$ & $\begin{array}{c}0.012 \\
(0.003)\end{array}$ & $\begin{array}{c}0.012 \\
(0.003)\end{array}$ & $\begin{array}{c}0.012 \\
(0.003)\end{array}$ \\
\hline Observations & 74786 & 74655 & 75205 & 74699 & 103314 & 103107 & 105451 & 104693 \\
\hline Avg. $R^{2}$ & 0.290 & 0.296 & 0.315 & 0.318 & 0.059 & 0.060 & 0.059 & 0.060 \\
\hline Country FE & Yes & Yes & Yes & Yes & Yes & Yes & Yes & Yes \\
\hline
\end{tabular}

Note: This table presents cross-sectional regressions of credit risk (EDF in columns 1-4) or debt growth $(\triangle \mathrm{DEBT}$ in columns $5-8)$ on labor expense growth $(\triangle \mathrm{XLR})$ or labor share $(\mathrm{LS})$. Book leverage $(\mathrm{Lev})$ is used in all regressions. 
TABle A12-Firm LEVEl CREDIT RISK AND LABOR MARKETS.

\begin{tabular}{|c|c|c|c|c|c|c|c|c|}
\hline & & & $\overline{\mathrm{DF}}$ & & & $\Delta \mathrm{D}$ & EBT & \\
\hline$\Delta \mathrm{XLR}$ & $\begin{array}{l}-0.344 \\
(0.066)\end{array}$ & $\begin{array}{l}-0.150 \\
(0.056)\end{array}$ & & & $\begin{array}{c}0.051 \\
(0.008)\end{array}$ & $\begin{array}{l}-0.007 \\
(0.010)\end{array}$ & & \\
\hline LS & & & $\begin{array}{c}0.926 \\
(0.072)\end{array}$ & $\begin{array}{c}0.840 \\
(0.087)\end{array}$ & & & $\begin{array}{l}-0.018 \\
(0.006)\end{array}$ & $\begin{array}{l}-0.038 \\
(0.008)\end{array}$ \\
\hline$\Delta \mathrm{XLR} \times \mu$ & & $\begin{array}{l}-0.124 \\
(0.035)\end{array}$ & & & & $\begin{array}{c}0.029 \\
(0.003)\end{array}$ & & \\
\hline $\mathrm{LS} \times \mu$ & & & & $\begin{array}{c}0.060 \\
(0.013)\end{array}$ & & & & $\begin{array}{c}0.006 \\
(0.003)\end{array}$ \\
\hline$\mu$ & & $\begin{array}{c}-0.072 \\
(0.011)\end{array}$ & & $\begin{array}{l}-0.104 \\
(0.010)\end{array}$ & & $\begin{array}{l}-0.004 \\
(0.000)\end{array}$ & & $\begin{array}{l}-0.006 \\
(0.002)\end{array}$ \\
\hline LEV & $\begin{array}{c}5.719 \\
(1.136)\end{array}$ & $\begin{array}{c}5.689 \\
(1.135)\end{array}$ & $\begin{array}{c}5.208 \\
(1.035)\end{array}$ & $\begin{array}{c}5.209 \\
(1.007)\end{array}$ & $\begin{array}{l}-0.408 \\
(0.039)\end{array}$ & $\begin{array}{l}-0.400 \\
(0.039)\end{array}$ & $\begin{array}{l}-0.390 \\
(0.041)\end{array}$ & $\begin{array}{l}-0.385 \\
(0.042)\end{array}$ \\
\hline$\sigma$ & $\begin{array}{c}1.767 \\
(0.230)\end{array}$ & $\begin{array}{c}1.703 \\
(0.227)\end{array}$ & $\begin{array}{c}1.585 \\
(0.223)\end{array}$ & $\begin{array}{c}1.518 \\
(0.239)\end{array}$ & $\begin{array}{l}-0.006 \\
(0.004)\end{array}$ & $\begin{array}{l}-0.006 \\
(0.004)\end{array}$ & $\begin{array}{l}-0.004 \\
(0.003)\end{array}$ & $\begin{array}{c}-0.004 \\
(0.003)\end{array}$ \\
\hline WCTA & $\begin{array}{l}-1.830 \\
(0.350)\end{array}$ & $\begin{array}{l}-1.868 \\
(0.350)\end{array}$ & $\begin{array}{l}-1.763 \\
(0.348)\end{array}$ & $\begin{array}{l}-1.750 \\
(0.345)\end{array}$ & $\begin{array}{l}-0.029 \\
(0.021)\end{array}$ & $\begin{array}{c}-0.031 \\
(0.022)\end{array}$ & $\begin{array}{l}-0.066 \\
(0.034)\end{array}$ & $\begin{array}{l}-0.065 \\
(0.037)\end{array}$ \\
\hline RETA & $\begin{array}{l}-0.121 \\
(0.133)\end{array}$ & $\begin{array}{l}-0.125 \\
(0.126)\end{array}$ & $\begin{array}{c}-0.514 \\
(0.327)\end{array}$ & $\begin{array}{c}-0.528 \\
(0.291)\end{array}$ & $\begin{array}{c}-0.002 \\
(0.001)\end{array}$ & $\begin{array}{c}-0.002 \\
(0.001)\end{array}$ & $\begin{array}{l}-0.001 \\
(0.003)\end{array}$ & $\begin{array}{l}-0.000 \\
(0.002)\end{array}$ \\
\hline EBITTA & $\begin{array}{l}-2.065 \\
(0.753)\end{array}$ & $\begin{array}{l}-1.943 \\
(0.779)\end{array}$ & $\begin{array}{c}-1.824 \\
(1.287)\end{array}$ & $\begin{array}{c}-1.376 \\
(1.189)\end{array}$ & $\begin{array}{c}0.025 \\
(0.037)\end{array}$ & $\begin{array}{c}0.036 \\
(0.042)\end{array}$ & $\begin{array}{c}0.025 \\
(0.068)\end{array}$ & $\begin{array}{c}0.054 \\
(0.069)\end{array}$ \\
\hline SaleGr & $\begin{array}{l}-0.567 \\
(0.065)\end{array}$ & $\begin{array}{l}-0.592 \\
(0.075)\end{array}$ & $\begin{array}{c}-0.755 \\
(0.061)\end{array}$ & $\begin{array}{c}-0.810 \\
(0.075)\end{array}$ & $\begin{array}{c}0.069 \\
(0.008)\end{array}$ & $\begin{array}{c}0.056 \\
(0.005)\end{array}$ & $\begin{array}{c}0.116 \\
(0.011)\end{array}$ & $\begin{array}{c}0.113 \\
(0.009)\end{array}$ \\
\hline NITA & $\begin{array}{l}-0.515 \\
(0.349)\end{array}$ & $\begin{array}{l}-0.560 \\
(0.332)\end{array}$ & $\begin{array}{l}-2.165 \\
(0.674)\end{array}$ & $\begin{array}{l}-2.124 \\
(0.706)\end{array}$ & $\begin{array}{c}0.022 \\
(0.014)\end{array}$ & $\begin{array}{c}0.023 \\
(0.015)\end{array}$ & $\begin{array}{c}0.093 \\
(0.015)\end{array}$ & $\begin{array}{c}0.099 \\
(0.015)\end{array}$ \\
\hline CACL & $\begin{array}{c}0.032 \\
(0.007)\end{array}$ & $\begin{array}{c}0.032 \\
(0.008)\end{array}$ & $\begin{array}{c}0.045 \\
(0.006)\end{array}$ & $\begin{array}{c}0.047 \\
(0.008)\end{array}$ & $\begin{array}{c}0.001 \\
(0.001)\end{array}$ & $\begin{array}{c}0.001 \\
(0.001)\end{array}$ & $\begin{array}{c}0.004 \\
(0.001)\end{array}$ & $\begin{array}{c}0.004 \\
(0.001)\end{array}$ \\
\hline Invest & $\begin{array}{c}0.016 \\
(0.003)\end{array}$ & $\begin{array}{c}0.015 \\
(0.003)\end{array}$ & $\begin{array}{c}0.023 \\
(0.004)\end{array}$ & $\begin{array}{c}0.023 \\
(0.004)\end{array}$ & $\begin{array}{c}0.002 \\
(0.002)\end{array}$ & $\begin{array}{c}0.002 \\
(0.002)\end{array}$ & $\begin{array}{c}0.003 \\
(0.002)\end{array}$ & $\begin{array}{c}0.003 \\
(0.002)\end{array}$ \\
\hline$R_{e x c}$ & $\begin{array}{l}-0.804 \\
(0.521)\end{array}$ & $\begin{array}{c}-0.744 \\
(0.532)\end{array}$ & $\begin{array}{l}-0.634 \\
(0.537)\end{array}$ & $\begin{array}{l}-0.534 \\
(0.487)\end{array}$ & $\begin{array}{c}0.066 \\
(0.024)\end{array}$ & $\begin{array}{c}0.070 \\
(0.026)\end{array}$ & $\begin{array}{c}0.065 \\
(0.023)\end{array}$ & $\begin{array}{c}0.066 \\
(0.023)\end{array}$ \\
\hline RSIZE & $\begin{array}{c}0.521 \\
(0.536)\end{array}$ & $\begin{array}{c}0.511 \\
(0.535)\end{array}$ & $\begin{array}{c}0.374 \\
(0.418)\end{array}$ & $\begin{array}{c}0.373 \\
(0.415)\end{array}$ & $\begin{array}{l}-0.012 \\
(0.007)\end{array}$ & $\begin{array}{l}-0.012 \\
(0.006)\end{array}$ & $\begin{array}{l}-0.013 \\
(0.006)\end{array}$ & $\begin{array}{l}-0.013 \\
(0.007)\end{array}$ \\
\hline$R_{m}$ & $\begin{array}{l}7.840 \\
(2.265)\end{array}$ & $\begin{array}{c}7.914 \\
(2.216)\end{array}$ & $\begin{array}{c}6.523 \\
(1.799)\end{array}$ & $\begin{array}{c}6.502 \\
(1.801)\end{array}$ & $\begin{array}{l}-0.156 \\
(0.060)\end{array}$ & $\begin{array}{l}-0.155 \\
(0.061)\end{array}$ & $\begin{array}{l}-0.125 \\
(0.071)\end{array}$ & $\begin{array}{l}-0.131 \\
(0.071)\end{array}$ \\
\hline MCAP & $\begin{array}{l}-0.927 \\
(0.595)\end{array}$ & $\begin{array}{c}-0.921 \\
(0.592)\end{array}$ & $\begin{array}{c}-0.727 \\
(0.465)\end{array}$ & $\begin{array}{c}-0.729 \\
(0.462)\end{array}$ & $\begin{array}{c}0.016 \\
(0.006)\end{array}$ & $\begin{array}{c}0.016 \\
(0.006)\end{array}$ & $\begin{array}{c}0.016 \\
(0.005)\end{array}$ & $\begin{array}{c}0.016 \\
(0.006)\end{array}$ \\
\hline Observations & 72041 & 71915 & 72194 & 71710 & 80610 & 80445 & 82232 & 81677 \\
\hline Avg. $R^{2}$ & 0.363 & 0.368 & 0.371 & 0.374 & 0.065 & 0.065 & 0.065 & 0.066 \\
\hline Country FE & Yes & Yes & Yes & Yes & Yes & Yes & Yes & Yes \\
\hline
\end{tabular}


TABLE A13-FirM LEVEL CREDIT RISK AND LABOR MARKETS (CONTROLLING FOR NET HIRING).

\begin{tabular}{|c|c|c|c|c|c|c|c|c|}
\hline \multirow{2}{*}{$\Delta \mathrm{XLR}$} & \multicolumn{4}{|c|}{ EDF } & \multicolumn{4}{|c|}{$\Delta \mathrm{DEBT}$} \\
\hline & $\begin{array}{l}-0.193 \\
(0.080)\end{array}$ & $\begin{array}{c}0.041 \\
(0.083)\end{array}$ & & & $\begin{array}{c}0.019 \\
(0.005)\end{array}$ & $\begin{array}{l}-0.036 \\
(0.014)\end{array}$ & & \\
\hline LS & & & $\begin{array}{c}0.613 \\
(0.092)\end{array}$ & $\begin{array}{c}0.386 \\
(0.090)\end{array}$ & & & $\begin{array}{l}-0.019 \\
(0.005)\end{array}$ & $\begin{array}{l}-0.031 \\
(0.010)\end{array}$ \\
\hline$\Delta \mathrm{XLR} \times \mu$ & & $\begin{array}{l}-0.150 \\
(0.045)\end{array}$ & & & & $\begin{array}{c}0.027 \\
(0.004)\end{array}$ & & \\
\hline $\mathrm{LS} \times \mu$ & & & & $\begin{array}{c}0.091 \\
(0.012)\end{array}$ & & & & $\begin{array}{c}0.003 \\
(0.003)\end{array}$ \\
\hline$\mu$ & & $\begin{array}{l}-0.047 \\
(0.012)\end{array}$ & & $\begin{array}{l}-0.108 \\
(0.013)\end{array}$ & & $\begin{array}{l}-0.004 \\
(0.001)\end{array}$ & & $\begin{array}{l}-0.005 \\
(0.002)\end{array}$ \\
\hline $\mathrm{HN}$ & $\begin{array}{l}-0.801 \\
(0.099)\end{array}$ & $\begin{array}{c}-0.740 \\
(0.096)\end{array}$ & $\begin{array}{c}-0.652 \\
(0.081)\end{array}$ & $\begin{array}{l}-0.697 \\
(0.067)\end{array}$ & $\begin{array}{c}0.161 \\
(0.017)\end{array}$ & $\begin{array}{c}0.149 \\
(0.018)\end{array}$ & $\begin{array}{c}0.168 \\
(0.018)\end{array}$ & $\begin{array}{c}0.165 \\
(0.019)\end{array}$ \\
\hline LEV & $\begin{array}{c}4.271 \\
(1.072)\end{array}$ & $\begin{array}{c}4.249 \\
(1.066)\end{array}$ & $\begin{array}{c}3.610 \\
(0.953)\end{array}$ & $\begin{array}{c}3.608 \\
(0.946)\end{array}$ & $\begin{array}{l}-0.526 \\
(0.067)\end{array}$ & $\begin{array}{l}-0.524 \\
(0.066)\end{array}$ & $\begin{array}{l}-0.506 \\
(0.062)\end{array}$ & $\begin{array}{c}-0.503 \\
(0.060)\end{array}$ \\
\hline$\sigma$ & $\begin{array}{c}1.789 \\
(0.380)\end{array}$ & $\begin{array}{c}1.760 \\
(0.381)\end{array}$ & $\begin{array}{c}1.602 \\
(0.373)\end{array}$ & $\begin{array}{c}1.574 \\
(0.373)\end{array}$ & $\begin{array}{l}-0.016 \\
(0.004)\end{array}$ & $\begin{array}{c}-0.016 \\
(0.004)\end{array}$ & $\begin{array}{l}-0.014 \\
(0.004)\end{array}$ & $\begin{array}{l}-0.014 \\
(0.004)\end{array}$ \\
\hline WCTA & $\begin{array}{l}-2.435 \\
(0.395)\end{array}$ & $\begin{array}{l}-2.413 \\
(0.395)\end{array}$ & $\begin{array}{c}-1.988 \\
(0.360)\end{array}$ & $\begin{array}{l}-1.976 \\
(0.357)\end{array}$ & $\begin{array}{l}-0.077 \\
(0.038)\end{array}$ & $\begin{array}{c}-0.077 \\
(0.038)\end{array}$ & $\begin{array}{l}-0.099 \\
(0.040)\end{array}$ & $\begin{array}{l}-0.099 \\
(0.041)\end{array}$ \\
\hline RETA & $\begin{array}{l}-0.184 \\
(0.220)\end{array}$ & $\begin{array}{l}-0.176 \\
(0.210)\end{array}$ & $\begin{array}{l}-0.621 \\
(0.427)\end{array}$ & $\begin{array}{l}-0.675 \\
(0.474)\end{array}$ & $\begin{array}{l}-0.021 \\
(0.010)\end{array}$ & $\begin{array}{l}-0.021 \\
(0.010)\end{array}$ & $\begin{array}{l}-0.020 \\
(0.009)\end{array}$ & $\begin{array}{l}-0.020 \\
(0.007)\end{array}$ \\
\hline EBITTA & $\begin{array}{l}-2.894 \\
(0.966)\end{array}$ & $\begin{array}{l}-2.838 \\
(1.005)\end{array}$ & $\begin{array}{l}-4.339 \\
(0.989)\end{array}$ & $\begin{array}{l}-3.997 \\
(0.959)\end{array}$ & $\begin{array}{c}0.124 \\
(0.083)\end{array}$ & $\begin{array}{c}0.133 \\
(0.086)\end{array}$ & $\begin{array}{c}0.174 \\
(0.131)\end{array}$ & $\begin{array}{c}0.197 \\
(0.133)\end{array}$ \\
\hline SaleGr & $\begin{array}{l}-0.562 \\
(0.099)\end{array}$ & $\begin{array}{l}-0.567 \\
(0.113)\end{array}$ & $\begin{array}{c}-0.574 \\
(0.097)\end{array}$ & $\begin{array}{c}-0.622 \\
(0.110)\end{array}$ & $\begin{array}{c}0.048 \\
(0.010)\end{array}$ & $\begin{array}{c}0.036 \\
(0.012)\end{array}$ & $\begin{array}{c}0.058 \\
(0.009)\end{array}$ & $\begin{array}{c}0.052 \\
(0.008)\end{array}$ \\
\hline NITA & $\begin{array}{l}-0.439 \\
(0.524)\end{array}$ & $\begin{array}{c}-0.515 \\
(0.486)\end{array}$ & $\begin{array}{c}-2.287 \\
(1.114)\end{array}$ & $\begin{array}{l}-2.265 \\
(1.119)\end{array}$ & $\begin{array}{l}-0.020 \\
(0.034)\end{array}$ & $\begin{array}{l}-0.015 \\
(0.033)\end{array}$ & $\begin{array}{c}0.086 \\
(0.034)\end{array}$ & $\begin{array}{c}0.087 \\
(0.034)\end{array}$ \\
\hline CACL & $\begin{array}{c}0.011 \\
(0.021)\end{array}$ & $\begin{array}{c}0.008 \\
(0.021)\end{array}$ & $\begin{array}{c}0.008 \\
(0.023)\end{array}$ & $\begin{array}{c}0.010 \\
(0.025)\end{array}$ & $\begin{array}{c}0.004 \\
(0.003)\end{array}$ & $\begin{array}{c}0.004 \\
(0.002)\end{array}$ & $\begin{array}{c}0.005 \\
(0.003)\end{array}$ & $\begin{array}{c}0.005 \\
(0.003)\end{array}$ \\
\hline Invest & $\begin{array}{c}0.031 \\
(0.011)\end{array}$ & $\begin{array}{c}0.030 \\
(0.010)\end{array}$ & $\begin{array}{c}0.021 \\
(0.013)\end{array}$ & $\begin{array}{c}0.019 \\
(0.012)\end{array}$ & $\begin{array}{c}0.007 \\
(0.005)\end{array}$ & $\begin{array}{c}0.007 \\
(0.005)\end{array}$ & $\begin{array}{c}0.008 \\
(0.005)\end{array}$ & $\begin{array}{c}0.008 \\
(0.005)\end{array}$ \\
\hline$R_{e x c}$ & $\begin{array}{l}-1.090 \\
(0.367)\end{array}$ & $\begin{array}{l}-1.028 \\
(0.377)\end{array}$ & $\begin{array}{l}-1.103 \\
(0.440)\end{array}$ & $\begin{array}{l}-1.060 \\
(0.453)\end{array}$ & $\begin{array}{c}0.042 \\
(0.018)\end{array}$ & $\begin{array}{c}0.044 \\
(0.021)\end{array}$ & $\begin{array}{c}0.041 \\
(0.016)\end{array}$ & $\begin{array}{c}0.043 \\
(0.018)\end{array}$ \\
\hline RSIZE & $\begin{array}{c}0.497 \\
(0.414)\end{array}$ & $\begin{array}{c}0.498 \\
(0.418)\end{array}$ & $\begin{array}{c}0.421 \\
(0.375)\end{array}$ & $\begin{array}{c}0.431 \\
(0.377)\end{array}$ & $\begin{array}{l}-0.001 \\
(0.005)\end{array}$ & $\begin{array}{c}-0.001 \\
(0.006)\end{array}$ & $\begin{array}{l}-0.001 \\
(0.007)\end{array}$ & $\begin{array}{l}-0.002 \\
(0.007)\end{array}$ \\
\hline$R_{m}$ & $\begin{array}{l}8.435 \\
(2.275)\end{array}$ & $\begin{array}{c}8.416 \\
(2.211)\end{array}$ & $\begin{array}{c}7.117 \\
(1.982)\end{array}$ & $\begin{array}{c}7.138 \\
(1.937)\end{array}$ & $\begin{array}{l}-0.215 \\
(0.051)\end{array}$ & $\begin{array}{l}-0.208 \\
(0.050)\end{array}$ & $\begin{array}{l}-0.179 \\
(0.059)\end{array}$ & $\begin{array}{l}-0.178 \\
(0.059)\end{array}$ \\
\hline MCAP & $\begin{array}{l}-0.966 \\
(0.494)\end{array}$ & $\begin{array}{l}-0.970 \\
(0.497)\end{array}$ & $\begin{array}{c}-0.824 \\
(0.439)\end{array}$ & $\begin{array}{l}-0.836 \\
(0.440)\end{array}$ & $\begin{array}{c}0.012 \\
(0.006)\end{array}$ & $\begin{array}{c}0.011 \\
(0.007)\end{array}$ & $\begin{array}{c}0.011 \\
(0.008)\end{array}$ & $\begin{array}{c}0.011 \\
(0.008)\end{array}$ \\
\hline Observations & 48458 & 48382 & 48293 & 48123 & 57412 & 57298 & 57788 & 57563 \\
\hline Avg. $R^{2}$ & 0.294 & 0.299 & 0.313 & 0.318 & 0.069 & 0.069 & 0.069 & 0.070 \\
\hline Country FE & Yes & Yes & Yes & Yes & Yes & Yes & Yes & Yes \\
\hline
\end{tabular}


TABle A14-Firm LeVEl CREDit Risk ANd labor markets (ALTERnAtive Rigidity measure).

\begin{tabular}{|c|c|c|c|c|}
\hline \multirow{2}{*}{$\Delta \mathrm{XLR}$} & \multicolumn{2}{|c|}{ EDF } & \multicolumn{2}{|c|}{$\Delta \mathrm{DEBT}$} \\
\hline & $\begin{array}{c}-0.330 \\
(0.078)\end{array}$ & & $\begin{array}{c}0.040 \\
(0.009)\end{array}$ & \\
\hline LS & & $\begin{array}{c}0.570 \\
(0.106)\end{array}$ & & $\begin{array}{l}-0.028 \\
(0.003)\end{array}$ \\
\hline$\Delta \mathrm{XLR} \times \mu$ & $\begin{array}{l}-0.968 \\
(0.148)\end{array}$ & & $\begin{array}{c}0.165 \\
(0.038)\end{array}$ & \\
\hline $\mathrm{LS} \times \mu$ & & $\begin{array}{c}0.491 \\
(0.210)\end{array}$ & & $\begin{array}{l}-0.006 \\
(0.029)\end{array}$ \\
\hline$\mu$ & $\begin{array}{c}0.710 \\
(0.139)\end{array}$ & $\begin{array}{c}0.139 \\
(0.133)\end{array}$ & $\begin{array}{l}-0.010 \\
(0.007)\end{array}$ & $\begin{array}{c}0.024 \\
(0.013)\end{array}$ \\
\hline $\mathrm{HN}$ & $\begin{array}{l}-0.694 \\
(0.120)\end{array}$ & $\begin{array}{l}-0.687 \\
(0.090)\end{array}$ & $\begin{array}{c}0.145 \\
(0.015)\end{array}$ & $\begin{array}{c}0.163 \\
(0.020)\end{array}$ \\
\hline LEV & $\begin{array}{c}4.183 \\
(1.037)\end{array}$ & $\begin{array}{c}3.489 \\
(0.942)\end{array}$ & $\begin{array}{l}-0.526 \\
(0.064)\end{array}$ & $\begin{array}{l}-0.502 \\
(0.062)\end{array}$ \\
\hline$\sigma$ & $\begin{array}{c}1.755 \\
(0.386)\end{array}$ & $\begin{array}{c}1.568 \\
(0.373)\end{array}$ & $\begin{array}{l}-0.015 \\
(0.004)\end{array}$ & $\begin{array}{l}-0.014 \\
(0.004)\end{array}$ \\
\hline WCTA & $\begin{array}{l}-2.415 \\
(0.413)\end{array}$ & $\begin{array}{l}-1.979 \\
(0.353)\end{array}$ & $\begin{array}{l}-0.084 \\
(0.033)\end{array}$ & $\begin{array}{l}-0.101 \\
(0.039)\end{array}$ \\
\hline RETA & $\begin{array}{l}-0.195 \\
(0.226)\end{array}$ & $\begin{array}{l}-0.732 \\
(0.514)\end{array}$ & $\begin{array}{l}-0.021 \\
(0.010)\end{array}$ & $\begin{array}{l}-0.018 \\
(0.006)\end{array}$ \\
\hline EBITTA & $\begin{array}{l}-2.928 \\
(0.966)\end{array}$ & $\begin{array}{l}-4.394 \\
(1.011)\end{array}$ & $\begin{array}{c}0.132 \\
(0.093)\end{array}$ & $\begin{array}{c}0.169 \\
(0.131)\end{array}$ \\
\hline SaleGr & $\begin{array}{l}-0.574 \\
(0.107)\end{array}$ & $\begin{array}{l}-0.646 \\
(0.121)\end{array}$ & $\begin{array}{c}0.035 \\
(0.014)\end{array}$ & $\begin{array}{c}0.052 \\
(0.009)\end{array}$ \\
\hline NITA & $\begin{array}{c}-0.561 \\
(0.439)\end{array}$ & $\begin{array}{l}-2.313 \\
(1.097)\end{array}$ & $\begin{array}{l}-0.015 \\
(0.030)\end{array}$ & $\begin{array}{c}0.100 \\
(0.034)\end{array}$ \\
\hline CACL & $\begin{array}{c}0.011 \\
(0.021)\end{array}$ & $\begin{array}{c}0.013 \\
(0.025)\end{array}$ & $\begin{array}{c}0.004 \\
(0.002)\end{array}$ & $\begin{array}{c}0.005 \\
(0.003)\end{array}$ \\
\hline Invest & $\begin{array}{c}0.029 \\
(0.013)\end{array}$ & $\begin{array}{c}0.017 \\
(0.014)\end{array}$ & $\begin{array}{c}0.007 \\
(0.005)\end{array}$ & $\begin{array}{c}0.007 \\
(0.005)\end{array}$ \\
\hline$R_{e x c}$ & $\begin{array}{l}-1.063 \\
(0.361)\end{array}$ & $\begin{array}{l}-1.094 \\
(0.469)\end{array}$ & $\begin{array}{c}0.040 \\
(0.020)\end{array}$ & $\begin{array}{c}0.041 \\
(0.018)\end{array}$ \\
\hline RSIZE & $\begin{array}{c}0.493 \\
(0.407)\end{array}$ & $\begin{array}{c}0.418 \\
(0.371)\end{array}$ & $\begin{array}{l}-0.001 \\
(0.005)\end{array}$ & $\begin{array}{l}-0.001 \\
(0.007)\end{array}$ \\
\hline$R_{m}$ & $\begin{array}{c}8.305 \\
(2.198)\end{array}$ & $\begin{array}{c}7.004 \\
(1.920)\end{array}$ & $\begin{array}{l}-0.214 \\
(0.053)\end{array}$ & $\begin{array}{l}-0.181 \\
(0.057)\end{array}$ \\
\hline MCAP & $\begin{array}{l}-0.954 \\
(0.487)\end{array}$ & $\begin{array}{l}-0.814 \\
(0.435)\end{array}$ & $\begin{array}{c}0.012 \\
(0.006)\end{array}$ & $\begin{array}{c}0.010 \\
(0.008)\end{array}$ \\
\hline Observations & 47827 & 47501 & 56674 & 56727 \\
\hline Avg. $R^{2}$ & 0.296 & 0.316 & 0.070 & 0.070 \\
\hline Country FE & Yes & Yes & Yes & Yes \\
\hline
\end{tabular}

Note: This table presents cross-sectional regressions of credit risk (EDF in columns 1-2) or debt growth $(\triangle \mathrm{DEBT}$ in columns 3-4) on labor expense growth $(\triangle \mathrm{XLR})$ or labor share (LS). These regressions are similar to those presented in Table 3 of the main text, but use an alternative measure of rigidity: $\mu=A C(\Delta X L R)$, where AC represents the first order autocorrelation. 
TABLE A15-FirM LEVEL CREDIT RISK AND LABOR MARKETS (WAGE INSTEAD OF LABOR EXPENSE GROWTH).

\begin{tabular}{|c|c|c|c|c|}
\hline \multirow{2}{*}{$\Delta \mathrm{WAGE}$} & \multicolumn{2}{|c|}{$\mathrm{EDF}$} & \multicolumn{2}{|c|}{$\triangle \mathrm{DEBT}$} \\
\hline & $\begin{array}{c}-0.224 \\
(0.058)\end{array}$ & $\begin{array}{c}-0.092 \\
(0.058)\end{array}$ & $\begin{array}{c}0.026 \\
(0.005)\end{array}$ & $\begin{array}{c}0.014 \\
(0.009)\end{array}$ \\
\hline$\Delta \mathrm{WAGE} \times \mu$ & & $\begin{array}{l}-0.087 \\
(0.032)\end{array}$ & & $\begin{array}{c}0.006 \\
(0.002)\end{array}$ \\
\hline$\mu$ & & $\begin{array}{l}-0.058 \\
(0.010)\end{array}$ & & $\begin{array}{l}-0.002 \\
(0.001)\end{array}$ \\
\hline $\mathrm{HN}$ & $\begin{array}{c}-1.026 \\
(0.100)\end{array}$ & $\begin{array}{l}-1.131 \\
(0.113)\end{array}$ & $\begin{array}{c}0.186 \\
(0.021)\end{array}$ & $\begin{array}{c}0.192 \\
(0.023)\end{array}$ \\
\hline LEV & $\begin{array}{c}4.265 \\
(1.074)\end{array}$ & $\begin{array}{c}4.243 \\
(1.066)\end{array}$ & $\begin{array}{l}-0.526 \\
(0.067)\end{array}$ & $\begin{array}{l}-0.524 \\
(0.066)\end{array}$ \\
\hline$\sigma$ & $\begin{array}{c}1.788 \\
(0.381)\end{array}$ & $\begin{array}{c}1.755 \\
(0.380)\end{array}$ & $\begin{array}{l}-0.016 \\
(0.004)\end{array}$ & $\begin{array}{l}-0.016 \\
(0.004)\end{array}$ \\
\hline WCTA & $\begin{array}{l}-2.439 \\
(0.396)\end{array}$ & $\begin{array}{l}-2.415 \\
(0.396)\end{array}$ & $\begin{array}{l}-0.078 \\
(0.038)\end{array}$ & $\begin{array}{l}-0.076 \\
(0.038)\end{array}$ \\
\hline RETA & $\begin{array}{l}-0.184 \\
(0.221)\end{array}$ & $\begin{array}{c}-0.176 \\
(0.210)\end{array}$ & $\begin{array}{l}-0.021 \\
(0.010)\end{array}$ & $\begin{array}{l}-0.021 \\
(0.010)\end{array}$ \\
\hline EBITTA & $\begin{array}{l}-2.881 \\
(0.967)\end{array}$ & $\begin{array}{l}-2.858 \\
(0.995)\end{array}$ & $\begin{array}{c}0.123 \\
(0.083)\end{array}$ & $\begin{array}{c}0.138 \\
(0.086)\end{array}$ \\
\hline SaleGr & $\begin{array}{c}-0.557 \\
(0.094)\end{array}$ & $\begin{array}{l}-0.554 \\
(0.106)\end{array}$ & $\begin{array}{c}0.046 \\
(0.010)\end{array}$ & $\begin{array}{c}0.036 \\
(0.011)\end{array}$ \\
\hline NITA & $\begin{array}{l}-0.446 \\
(0.530)\end{array}$ & $\begin{array}{l}-0.496 \\
(0.485)\end{array}$ & $\begin{array}{l}-0.020 \\
(0.033)\end{array}$ & $\begin{array}{l}-0.018 \\
(0.034)\end{array}$ \\
\hline CACL & $\begin{array}{c}0.011 \\
(0.021)\end{array}$ & $\begin{array}{c}0.008 \\
(0.021)\end{array}$ & $\begin{array}{c}0.004 \\
(0.003)\end{array}$ & $\begin{array}{c}0.004 \\
(0.002)\end{array}$ \\
\hline Invest & $\begin{array}{c}0.032 \\
(0.011)\end{array}$ & $\begin{array}{c}0.031 \\
(0.011)\end{array}$ & $\begin{array}{c}0.007 \\
(0.005)\end{array}$ & $\begin{array}{c}0.007 \\
(0.005)\end{array}$ \\
\hline$R_{e x c}$ & $\begin{array}{l}-1.094 \\
(0.368)\end{array}$ & $\begin{array}{l}-1.035 \\
(0.377)\end{array}$ & $\begin{array}{c}0.042 \\
(0.018)\end{array}$ & $\begin{array}{c}0.042 \\
(0.021)\end{array}$ \\
\hline RSIZE & $\begin{array}{c}0.496 \\
(0.414)\end{array}$ & $\begin{array}{c}0.503 \\
(0.425)\end{array}$ & $\begin{array}{l}-0.001 \\
(0.005)\end{array}$ & $\begin{array}{l}-0.001 \\
(0.006)\end{array}$ \\
\hline$R_{m}$ & $\begin{array}{c}8.433 \\
(2.269)\end{array}$ & $\begin{array}{c}8.431 \\
(2.213)\end{array}$ & $\begin{array}{l}-0.214 \\
(0.051)\end{array}$ & $\begin{array}{l}-0.209 \\
(0.050)\end{array}$ \\
\hline MCAP & $\begin{array}{l}-0.965 \\
(0.494)\end{array}$ & $\begin{array}{c}-0.976 \\
(0.504)\end{array}$ & $\begin{array}{c}0.012 \\
(0.006)\end{array}$ & $\begin{array}{c}0.012 \\
(0.006)\end{array}$ \\
\hline Observations & 48452 & 48376 & 57407 & 57294 \\
\hline Avg. $R^{2}$ & 0.294 & 0.299 & 0.069 & 0.069 \\
\hline Country FE & Yes & Yes & Yes & Yes \\
\hline
\end{tabular}

Note: This table presents cross-sectional regressions of credit risk (EDF in columns 1-2) or debt growth ( $\triangle$ DEBT in columns $3-4)$ on wage growth ( $\triangle$ WAGE). These regressions are similar to those presented in Tables 2 and 3 of the main text, but uses wage growth instead of compensation growth. 
TABle A16-Firm Level CDS SPREAd AND LABor MARKET VARIABles.

\begin{tabular}{|c|c|c|c|c|c|c|c|c|}
\hline & \multicolumn{4}{|c|}{ CDS 5-year Spread } & \multicolumn{4}{|c|}{ CDS 1-year Spread } \\
\hline & (1) & $(2)$ & $(3)$ & $(4)$ & (5) & $(6)$ & $(7)$ & $(8)$ \\
\hline$\Delta \mathrm{XLR}$ & $\begin{array}{l}-0.37 \\
(0.17)\end{array}$ & $\begin{array}{c}0.09 \\
(0.16)\end{array}$ & & & $\begin{array}{l}-0.53 \\
(0.19)\end{array}$ & $\begin{array}{c}0.10 \\
(0.23)\end{array}$ & & \\
\hline LS & & & $\begin{array}{c}1.78 \\
(0.38)\end{array}$ & $\begin{array}{c}0.65 \\
(0.31)\end{array}$ & & & $\begin{array}{c}2.01 \\
(0.53)\end{array}$ & $\begin{array}{c}0.98 \\
(0.25)\end{array}$ \\
\hline$\Delta \mathrm{XLR} \times \mu$ & & $\begin{array}{c}-0.34 \\
(0.10)\end{array}$ & & & & $\begin{array}{c}-0.54 \\
(0.16)\end{array}$ & & \\
\hline $\mathrm{LS} \times \mu$ & & & & $\begin{array}{c}0.30 \\
(0.10)\end{array}$ & & & & $\begin{array}{c}0.26 \\
(0.10)\end{array}$ \\
\hline$\mu$ & & $\begin{array}{c}-0.03 \\
(0.02)\end{array}$ & & $\begin{array}{l}-0.21 \\
(0.06)\end{array}$ & & $\begin{array}{c}0.01 \\
(0.04)\end{array}$ & & $\begin{array}{c}-0.20 \\
(0.07)\end{array}$ \\
\hline LEV & $\begin{array}{c}1.41 \\
(0.46)\end{array}$ & $\begin{array}{c}1.44 \\
(0.45)\end{array}$ & $\begin{array}{c}1.83 \\
(0.64)\end{array}$ & $\begin{array}{c}2.00 \\
(0.61)\end{array}$ & $\begin{array}{c}1.30 \\
(0.74)\end{array}$ & $\begin{array}{c}1.42 \\
(0.71)\end{array}$ & $\begin{array}{c}1.14 \\
(0.89)\end{array}$ & $\begin{array}{c}1.28 \\
(0.87)\end{array}$ \\
\hline$\sigma$ & $\begin{array}{c}1.20 \\
(0.46)\end{array}$ & $\begin{array}{c}1.16 \\
(0.45)\end{array}$ & $\begin{array}{c}1.45 \\
(0.54)\end{array}$ & $\begin{array}{c}1.38 \\
(0.51)\end{array}$ & $\begin{array}{c}1.91 \\
(0.70)\end{array}$ & $\begin{array}{c}1.88 \\
(0.69)\end{array}$ & $\begin{array}{c}1.83 \\
(0.69)\end{array}$ & $\begin{array}{c}1.75 \\
(0.65)\end{array}$ \\
\hline WCTA & $\begin{array}{c}1.38 \\
(0.55)\end{array}$ & $\begin{array}{c}1.44 \\
(0.55)\end{array}$ & $\begin{array}{c}1.64 \\
(0.75)\end{array}$ & $\begin{array}{c}1.45 \\
(0.82)\end{array}$ & $\begin{array}{c}1.22 \\
(0.39)\end{array}$ & $\begin{array}{c}1.26 \\
(0.36)\end{array}$ & $\begin{array}{c}0.98 \\
(0.73)\end{array}$ & $\begin{array}{c}0.89 \\
(0.76)\end{array}$ \\
\hline RETA & $\begin{array}{c}-2.49 \\
(0.37)\end{array}$ & $\begin{array}{l}-2.44 \\
(0.38)\end{array}$ & $\begin{array}{l}-2.42 \\
(0.42)\end{array}$ & $\begin{array}{l}-2.34 \\
(0.42)\end{array}$ & $\begin{array}{l}-2.38 \\
(0.66)\end{array}$ & $\begin{array}{l}-2.34 \\
(0.66)\end{array}$ & $\begin{array}{l}-2.45 \\
(0.62)\end{array}$ & $\begin{array}{l}-2.39 \\
(0.61)\end{array}$ \\
\hline EBITTA & $\begin{array}{l}-7.25 \\
(1.18)\end{array}$ & $\begin{array}{l}-7.49 \\
(1.15)\end{array}$ & $\begin{array}{l}-5.58 \\
(0.91)\end{array}$ & $\begin{array}{l}-5.46 \\
(0.91)\end{array}$ & $\begin{array}{l}-4.29 \\
(1.25)\end{array}$ & $\begin{array}{l}-4.66 \\
(1.19)\end{array}$ & $\begin{array}{c}-3.72 \\
(1.22)\end{array}$ & $\begin{array}{c}-3.73 \\
(1.22)\end{array}$ \\
\hline SaleGr & $\begin{array}{l}-0.74 \\
(0.66)\end{array}$ & $\begin{array}{l}-0.46 \\
(0.72)\end{array}$ & $\begin{array}{l}-0.89 \\
(0.89)\end{array}$ & $\begin{array}{l}-0.92 \\
(0.89)\end{array}$ & $\begin{array}{c}1.12 \\
(0.89)\end{array}$ & $\begin{array}{c}1.65 \\
(1.05)\end{array}$ & $\begin{array}{c}0.09 \\
(1.24)\end{array}$ & $\begin{array}{c}0.04 \\
(1.24)\end{array}$ \\
\hline NITA & $\begin{array}{c}-5.78 \\
(1.38)\end{array}$ & $\begin{array}{c}-5.64 \\
(1.36)\end{array}$ & $\begin{array}{l}-5.76 \\
(1.42)\end{array}$ & $\begin{array}{l}-5.72 \\
(1.41)\end{array}$ & $\begin{array}{l}-8.90 \\
(2.42)\end{array}$ & $\begin{array}{l}-8.69 \\
(2.36)\end{array}$ & $\begin{array}{l}-9.09 \\
(2.70)\end{array}$ & $\begin{array}{l}-9.11 \\
(2.72)\end{array}$ \\
\hline CACL & $\begin{array}{l}-0.18 \\
(0.04)\end{array}$ & $\begin{array}{l}-0.19 \\
(0.05)\end{array}$ & $\begin{array}{l}-0.16 \\
(0.03)\end{array}$ & $\begin{array}{l}-0.15 \\
(0.03)\end{array}$ & $\begin{array}{l}-0.22 \\
(0.04)\end{array}$ & $\begin{array}{l}-0.23 \\
(0.04)\end{array}$ & $\begin{array}{l}-0.15 \\
(0.02)\end{array}$ & $\begin{array}{l}-0.14 \\
(0.02)\end{array}$ \\
\hline Invest & $\begin{array}{c}0.10 \\
(0.22)\end{array}$ & $\begin{array}{c}0.04 \\
(0.21)\end{array}$ & $\begin{array}{c}0.33 \\
(0.23)\end{array}$ & $\begin{array}{c}0.23 \\
(0.24)\end{array}$ & $\begin{array}{c}-0.47 \\
(0.26)\end{array}$ & $\begin{array}{l}-0.52 \\
(0.30)\end{array}$ & $\begin{array}{l}-0.18 \\
(0.34)\end{array}$ & $\begin{array}{l}-0.29 \\
(0.40)\end{array}$ \\
\hline$R_{e x c}$ & $\begin{array}{c}1.10 \\
(0.84)\end{array}$ & $\begin{array}{c}1.10 \\
(0.84)\end{array}$ & $\begin{array}{c}0.72 \\
(0.63)\end{array}$ & $\begin{array}{c}0.76 \\
(0.63)\end{array}$ & $\begin{array}{c}0.40 \\
(0.68)\end{array}$ & $\begin{array}{c}0.28 \\
(0.68)\end{array}$ & $\begin{array}{c}1.13 \\
(0.83)\end{array}$ & $\begin{array}{c}1.20 \\
(0.84)\end{array}$ \\
\hline RSIZE & $\begin{array}{l}-0.11 \\
(0.44)\end{array}$ & $\begin{array}{l}-0.07 \\
(0.43)\end{array}$ & $\begin{array}{c}0.30 \\
(0.46)\end{array}$ & $\begin{array}{c}0.28 \\
(0.46)\end{array}$ & $\begin{array}{c}0.01 \\
(0.57)\end{array}$ & $\begin{array}{c}0.10 \\
(0.57)\end{array}$ & $\begin{array}{c}0.37 \\
(0.55)\end{array}$ & $\begin{array}{c}0.32 \\
(0.54)\end{array}$ \\
\hline$R_{m}$ & $\begin{array}{l}-0.27 \\
(2.50)\end{array}$ & $\begin{array}{l}-0.20 \\
(2.47)\end{array}$ & $\begin{array}{l}-3.30 \\
(3.57)\end{array}$ & $\begin{array}{l}-2.97 \\
(3.40)\end{array}$ & $\begin{array}{l}-4.94 \\
(3.84)\end{array}$ & $\begin{array}{l}-4.90 \\
(3.87)\end{array}$ & $\begin{array}{l}-7.08 \\
(4.67)\end{array}$ & $\begin{array}{l}-6.80 \\
(4.52)\end{array}$ \\
\hline MCAP & $\begin{array}{c}-0.27 \\
(0.29)\end{array}$ & $\begin{array}{l}-0.30 \\
(0.29)\end{array}$ & $\begin{array}{l}-0.51 \\
(0.38)\end{array}$ & $\begin{array}{c}-0.49 \\
(0.38)\end{array}$ & $\begin{array}{l}-0.29 \\
(0.40)\end{array}$ & $\begin{array}{l}-0.38 \\
(0.40)\end{array}$ & $\begin{array}{l}-0.45 \\
(0.42)\end{array}$ & $\begin{array}{c}-0.40 \\
(0.41)\end{array}$ \\
\hline Observations & 3801 & 3801 & 3772 & 3772 & 3503 & 3503 & 3479 & 3479 \\
\hline Avg. $R^{2}$ & 0.383 & 0.389 & 0.401 & 0.408 & 0.368 & 0.379 & 0.384 & 0.390 \\
\hline Country FE & Yes & Yes & Yes & Yes & Yes & Yes & Yes & Yes \\
\hline
\end{tabular}




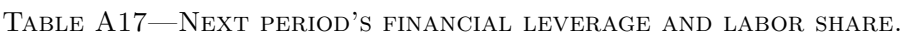

\begin{tabular}{|c|c|c|c|c|c|c|c|c|}
\hline \multirow{2}{*}{$\mathrm{LS}_{t}$} & \multicolumn{4}{|c|}{$\mathrm{LEVM}_{t+1}$} & \multicolumn{4}{|c|}{$\mathrm{LEVB}_{t+1}$} \\
\hline & $\begin{array}{l}-0.007 \\
(0.010)\end{array}$ & $\begin{array}{c}0.001 \\
(0.003)\end{array}$ & $\begin{array}{c}-0.003 \\
(0.001)\end{array}$ & $\begin{array}{c}-0.006 \\
(0.001)\end{array}$ & $\begin{array}{c}-0.019 \\
(0.005)\end{array}$ & $\begin{array}{c}-0.015 \\
(0.001)\end{array}$ & $\begin{array}{c}-0.003 \\
(0.002)\end{array}$ & $\begin{array}{c}-0.003 \\
(0.001)\end{array}$ \\
\hline $\mathrm{LEVM}_{t}$ & & & $\begin{array}{c}0.863 \\
(0.014)\end{array}$ & $\begin{array}{c}0.858 \\
(0.016)\end{array}$ & & & & \\
\hline $\mathrm{LEVB}_{t}$ & & & & & & & $\begin{array}{c}0.862 \\
(0.012)\end{array}$ & $\begin{array}{c}0.865 \\
(0.007)\end{array}$ \\
\hline$\sigma$ & & & & $\begin{array}{c}-0.001 \\
(0.001)\end{array}$ & & & & $\begin{array}{l}-0.001 \\
(0.001)\end{array}$ \\
\hline WCTA & & & & $\begin{array}{c}-0.028 \\
(0.007)\end{array}$ & & & & $\begin{array}{c}-0.017 \\
(0.005)\end{array}$ \\
\hline RETA & & & & $\begin{array}{c}0.003 \\
(0.001)\end{array}$ & & & & $\begin{array}{c}-0.000 \\
(0.001)\end{array}$ \\
\hline EBITTA & & & & $\begin{array}{c}-0.052 \\
(0.005)\end{array}$ & & & & $\begin{array}{c}-0.021 \\
(0.014)\end{array}$ \\
\hline SaleGr & & & & $\begin{array}{c}0.011 \\
(0.001)\end{array}$ & & & & $\begin{array}{c}0.003 \\
(0.001)\end{array}$ \\
\hline NITA & & & & $\begin{array}{c}0.020 \\
(0.007)\end{array}$ & & & & $\begin{array}{c}-0.000 \\
(0.004)\end{array}$ \\
\hline CACL & & & & $\begin{array}{c}0.001 \\
(0.000)\end{array}$ & & & & $\begin{array}{c}0.000 \\
(0.000)\end{array}$ \\
\hline Invest & & & & $\begin{array}{c}0.000 \\
(0.000)\end{array}$ & & & & $\begin{array}{c}0.000 \\
(0.000)\end{array}$ \\
\hline$R_{e x c}$ & & & & $\begin{array}{l}-0.005 \\
(0.003)\end{array}$ & & & & $\begin{array}{c}-0.013 \\
(0.001)\end{array}$ \\
\hline$R_{\text {size }}$ & & & & $\begin{array}{c}-0.008 \\
(0.002)\end{array}$ & & & & $\begin{array}{c}-0.001 \\
(0.001)\end{array}$ \\
\hline$R_{m}$ & & & & $\begin{array}{c}-0.006 \\
(0.020)\end{array}$ & & & & $\begin{array}{c}-0.022 \\
(0.005)\end{array}$ \\
\hline MCAP & & & & $\begin{array}{c}0.007 \\
(0.001)\end{array}$ & & & & $\begin{array}{c}0.002 \\
(0.001) \\
\end{array}$ \\
\hline Obs. & 101201 & 101201 & 94307 & 90490 & 101201 & 101201 & 100700 & 95180 \\
\hline Avg.R2 & 0.003 & 0.128 & 0.767 & 0.774 & 0.005 & 0.080 & 0.758 & 0.775 \\
\hline Country FE & No & Yes & Yes & Yes & No & Yes & Yes & Yes \\
\hline
\end{tabular}

Note: This table presents cross-sectional regressions of leverage at $t+1$ on labor share (LS) at $t$. 
Table A18-Financial Leverage and Labor share.

\begin{tabular}{|c|c|c|c|c|c|c|}
\hline \multirow{2}{*}{ LS } & \multicolumn{3}{|c|}{ LEVM } & \multicolumn{3}{|c|}{ LEVB } \\
\hline & $\begin{array}{l}-0.048 \\
(0.003)\end{array}$ & $\begin{array}{c}-0.026 \\
(0.003)\end{array}$ & $\begin{array}{c}-0.012 \\
(0.003)\end{array}$ & $\begin{array}{l}-0.040 \\
(0.002)\end{array}$ & $\begin{array}{l}-0.027 \\
(0.002)\end{array}$ & $\begin{array}{l}-0.010 \\
(0.002)\end{array}$ \\
\hline$\sigma$ & & & $\begin{array}{c}0.014 \\
(0.003)\end{array}$ & & & $\begin{array}{c}0.007 \\
(0.002)\end{array}$ \\
\hline WCTA & & & $\begin{array}{l}-0.275 \\
(0.006)\end{array}$ & & & $\begin{array}{l}-0.236 \\
(0.005)\end{array}$ \\
\hline RETA & & & $\begin{array}{c}0.010 \\
(0.001)\end{array}$ & & & $\begin{array}{c}0.007 \\
(0.001)\end{array}$ \\
\hline EBITTA & & & $\begin{array}{c}0.015 \\
(0.016)\end{array}$ & & & $\begin{array}{c}0.084 \\
(0.012)\end{array}$ \\
\hline SaleGr & & & $\begin{array}{l}-0.073 \\
(0.006)\end{array}$ & & & $\begin{array}{l}-0.015 \\
(0.005)\end{array}$ \\
\hline NITA & & & $\begin{array}{c}0.091 \\
(0.013)\end{array}$ & & & $\begin{array}{c}0.013 \\
(0.010)\end{array}$ \\
\hline CACL & & & $\begin{array}{l}-0.002 \\
(0.000)\end{array}$ & & & $\begin{array}{l}-0.000 \\
(0.000)\end{array}$ \\
\hline Invest & & & $\begin{array}{l}-0.000 \\
(0.001)\end{array}$ & & & $\begin{array}{l}-0.000 \\
(0.000)\end{array}$ \\
\hline$R_{e x c}$ & & & $\begin{array}{c}0.106 \\
(0.023)\end{array}$ & & & $\begin{array}{c}0.020 \\
(0.017)\end{array}$ \\
\hline$R_{\text {size }}$ & & & $\begin{array}{l}-0.001 \\
(0.003)\end{array}$ & & & $\begin{array}{c}0.009 \\
(0.002)\end{array}$ \\
\hline$R_{m}$ & & & $\begin{array}{c}0.204 \\
(0.045)\end{array}$ & & & $\begin{array}{l}-0.024 \\
(0.032)\end{array}$ \\
\hline MCAP & & & $\begin{array}{c}-0.014 \\
(0.003) \\
\end{array}$ & & & $\begin{array}{l}-0.006 \\
(0.002) \\
\end{array}$ \\
\hline Obs & 16224 & 16224 & 16074 & 16224 & 16224 & 16074 \\
\hline $\mathrm{R} 2$ & 0.019 & 0.112 & 0.237 & 0.024 & 0.106 & 0.254 \\
\hline Country FE & No & Yes & Yes & No & Yes & Yes \\
\hline
\end{tabular}

Note: This table presents cross-sectional regressions of each firm's average leverage over the entire sample, on average labor share (LS). These regressions are the same as those presented in Table 5 of the main text, but here, we also report coefficients associated with all of the controls. 
TABle A19-Time-Series CORRElation Between labor EXPEnSES AND EDF.

\begin{tabular}{|c|c|c|c|c|c|c|c|c|}
\hline \multirow[b]{2}{*}{ Country } & \multicolumn{4}{|c|}{$\operatorname{Corr}(\Delta X L R, E D F)$} & \multicolumn{4}{|c|}{$\operatorname{Corr}(L S, E D F)$} \\
\hline & Mean & St.D. & No of firms & St.Err. & Mean & St.D. & No of firms & St.Err. \\
\hline \multicolumn{9}{|l|}{ Region: Europe } \\
\hline Austria & -0.10 & 0.54 & 95 & 0.055 & 0.21 & 0.54 & 100 & 0.054 \\
\hline Belgium & 0.00 & 0.53 & 115 & 0.049 & 0.27 & 0.53 & 116 & 0.049 \\
\hline Denmark & -0.11 & 0.44 & 131 & 0.038 & 0.29 & 0.51 & 131 & 0.045 \\
\hline Finland & -0.08 & 0.40 & 135 & 0.035 & 0.33 & 0.40 & 137 & 0.035 \\
\hline France & -0.12 & 0.50 & 793 & 0.018 & 0.27 & 0.52 & 808 & 0.018 \\
\hline Germany & -0.11 & 0.50 & 701 & 0.019 & 0.27 & 0.51 & 694 & 0.019 \\
\hline Greece & -0.30 & 0.61 & 141 & 0.051 & 0.34 & 0.61 & 156 & 0.049 \\
\hline Italy & -0.13 & 0.46 & 263 & 0.029 & 0.29 & 0.53 & 265 & 0.033 \\
\hline Netherlands & -0.12 & 0.50 & 179 & 0.038 & 0.23 & 0.55 & 184 & 0.040 \\
\hline Norway & -0.11 & 0.57 & 199 & 0.041 & 0.25 & 0.59 & 196 & 0.042 \\
\hline Poland & 0.01 & 0.64 & 191 & 0.046 & 0.29 & 0.61 & 195 & 0.044 \\
\hline Portugal & -0.14 & 0.56 & 57 & 0.074 & 0.23 & 0.54 & 60 & 0.070 \\
\hline Spain & -0.07 & 0.46 & 151 & 0.038 & 0.22 & 0.54 & 155 & 0.044 \\
\hline Sweden & -0.07 & 0.53 & 296 & 0.031 & 0.28 & 0.58 & 293 & 0.034 \\
\hline Switzerland & -0.08 & 0.47 & 211 & 0.032 & 0.24 & 0.49 & 205 & 0.034 \\
\hline United Kingdom & -0.05 & 0.55 & 1736 & 0.013 & 0.28 & 0.58 & 1686 & 0.014 \\
\hline \multicolumn{9}{|c|}{ Region: North America } \\
\hline Canada & -0.06 & 0.66 & 257 & 0.041 & 0.30 & 0.68 & 79 & 0.076 \\
\hline United States & -0.10 & 0.65 & 671 & 0.025 & 0.18 & 0.66 & 671 & 0.025 \\
\hline \multicolumn{9}{|c|}{ Region: Asia Pacific and Australia } \\
\hline Australia & -0.01 & 0.61 & 1204 & 0.018 & 0.20 & 0.64 & 688 & 0.024 \\
\hline China & 0.04 & 0.58 & 79 & 0.065 & 0.23 & 0.58 & 87 & 0.062 \\
\hline Hong Kong & 0.17 & 0.53 & 169 & 0.041 & 0.14 & 0.53 & 164 & 0.041 \\
\hline India & 0.00 & 0.58 & 1242 & 0.016 & 0.20 & 0.58 & 1251 & 0.016 \\
\hline Indonesia & 0.07 & 0.61 & 213 & 0.042 & 0.05 & 0.59 & 216 & 0.040 \\
\hline Malaysia & -0.04 & 0.54 & 863 & 0.018 & 0.20 & 0.56 & 869 & 0.019 \\
\hline New Zealand & 0.08 & 0.73 & 84 & 0.079 & 0.33 & 0.63 & 83 & 0.069 \\
\hline Philippines & -0.01 & 0.52 & 85 & 0.057 & 0.22 & 0.57 & 82 & 0.063 \\
\hline Singapore & 0.04 & 0.55 & 507 & 0.024 & 0.24 & 0.52 & 512 & 0.023 \\
\hline S. Korea & -0.16 & 0.96 & 6 & 0.392 & 0.06 & 0.91 & 9 & 0.304 \\
\hline Taiwan & 0.94 & & 1 & & 0.57 & 0.87 & 4 & 0.434 \\
\hline Thailand & 0.06 & 0.63 & 278 & 0.038 & 0.20 & 0.60 & 286 & 0.035 \\
\hline \multicolumn{9}{|c|}{ Region: Latin America } \\
\hline Argentina & 0.08 & 0.66 & 36 & 0.110 & 0.24 & 0.58 & 42 & 0.089 \\
\hline Brazil & 0.10 & 0.73 & 73 & 0.086 & 0.13 & 0.66 & 71 & 0.078 \\
\hline Chile & -0.06 & 0.86 & 9 & 0.286 & 0.01 & 0.94 & 38 & 0.153 \\
\hline Mexico & 0.15 & 0.80 & 28 & 0.152 & 0.38 & 0.73 & 36 & 0.122 \\
\hline \multicolumn{9}{|c|}{ Region: Greater Middle East and Africa } \\
\hline Israel & -0.13 & 0.59 & 104 & 0.058 & 0.12 & 0.60 & 104 & 0.059 \\
\hline Pakistan & -0.04 & 0.52 & 97 & 0.053 & 0.14 & 0.58 & 103 & 0.057 \\
\hline Turkey & 0.19 & 0.61 & 102 & 0.060 & 0.18 & 0.62 & 113 & 0.059 \\
\hline South Africa & -0.02 & 0.65 & 175 & 0.049 & 0.21 & 0.61 & 196 & 0.044 \\
\hline Total & -0.04 & 0.57 & 11677 & 0.005 & 0.23 & 0.58 & 11085 & 0.005 \\
\hline $\begin{array}{l}\text { Note: This table rep } \\
\text { penses growth and } \\
(C o r r(L S, E D F)) \text {. } \\
\text { ery firm, we calculate } \\
\text { we report the mean a } \\
\text { the same summary st } \\
\text { whether } \operatorname{Corr}(\Delta X L F\end{array}$ & $\begin{array}{l}\text { tistics } \\
E D F)\end{array}$ & Di, D & $\begin{array}{l}\text { of of the fir } \\
E D F) \text {, an }\end{array}$ & row "I & " T & chent & $\begin{array}{l}\text { between lak } \\
\text { share an } \\
\text { variable. }\end{array}$ & $\begin{array}{l}\text { ex- } \\
\text { EDF } \\
\text { ev- } \\
\text { hen } \\
\text { port } \\
\text { ting }\end{array}$ \\
\hline
\end{tabular}


TABle A20-Time-SERIES CORRELATION BETWEen LABOR EXPENSES AND DEBT GROWTH.

\begin{tabular}{|c|c|c|c|c|c|c|c|c|}
\hline & \multicolumn{4}{|c|}{$\operatorname{Corr}(\triangle X L R, \triangle D E B T)$} & \multicolumn{4}{|c|}{$\operatorname{Corr}(L S, \triangle D E B T)$} \\
\hline Country & Mean & St.D. & No of firms & St.Err. & Mean & St.D. & No of firms & St.Err. \\
\hline \multicolumn{9}{|l|}{ Region: Europe } \\
\hline Austria & 0.02 & 0.44 & 111 & 0.042 & -0.11 & 0.47 & 119 & 0.044 \\
\hline Belgium & -0.07 & 0.45 & 141 & 0.038 & -0.02 & 0.46 & 141 & 0.039 \\
\hline Denmark & 0.01 & 0.47 & 172 & 0.036 & -0.12 & 0.46 & 178 & 0.035 \\
\hline Finland & -0.09 & 0.40 & 153 & 0.033 & -0.11 & 0.42 & 158 & 0.034 \\
\hline France & -0.02 & 0.45 & 909 & 0.015 & -0.06 & 0.46 & 930 & 0.015 \\
\hline Germany & -0.01 & 0.48 & 833 & 0.017 & -0.08 & 0.47 & 844 & 0.016 \\
\hline Greece & 0.10 & 0.55 & 203 & 0.039 & -0.11 & 0.50 & 209 & 0.035 \\
\hline Italy & -0.06 & 0.45 & 323 & 0.025 & -0.04 & 0.46 & 333 & 0.025 \\
\hline Netherlands & -0.01 & 0.46 & 199 & 0.033 & -0.12 & 0.45 & 209 & 0.031 \\
\hline Norway & 0.08 & 0.55 & 248 & 0.035 & -0.03 & 0.59 & 247 & 0.038 \\
\hline Poland & 0.07 & 0.57 & 389 & 0.029 & -0.11 & 0.55 & 409 & 0.027 \\
\hline Portugal & -0.06 & 0.50 & 73 & 0.058 & -0.04 & 0.49 & 77 & 0.056 \\
\hline Spain & -0.01 & 0.38 & 171 & 0.029 & -0.04 & 0.43 & 177 & 0.032 \\
\hline Sweden & 0.10 & 0.54 & 418 & 0.027 & -0.06 & 0.56 & 407 & 0.028 \\
\hline Switzerland & 0.04 & 0.44 & 250 & 0.028 & -0.08 & 0.41 & 247 & 0.026 \\
\hline United Kingdom & 0.07 & 0.54 & 1861 & 0.012 & -0.08 & 0.55 & 1870 & 0.013 \\
\hline \multicolumn{9}{|c|}{ Region: North America } \\
\hline Canada & 0.12 & 0.72 & 231 & 0.048 & -0.03 & 0.88 & 333 & 0.048 \\
\hline United States & 0.01 & 0.62 & 1011 & 0.020 & -0.05 & 0.61 & 1016 & 0.019 \\
\hline \multicolumn{9}{|c|}{ Region: Asia Pacific and Australia } \\
\hline Australia & 0.09 & 0.63 & 1024 & 0.020 & -0.11 & 0.62 & 765 & 0.022 \\
\hline China & 0.07 & 0.51 & 153 & 0.041 & 0.00 & 0.52 & 164 & 0.041 \\
\hline Hong Kong & 0.02 & 0.56 & 318 & 0.031 & -0.04 & 0.57 & 320 & 0.032 \\
\hline India & 0.05 & 0.43 & 2452 & 0.009 & -0.04 & 0.43 & 2454 & 0.009 \\
\hline Indonesia & -0.03 & 0.51 & 312 & 0.029 & 0.05 & 0.53 & 340 & 0.029 \\
\hline Malaysia & 0.06 & 0.53 & 900 & 0.018 & -0.08 & 0.50 & 908 & 0.017 \\
\hline New Zealand & 0.04 & 0.58 & 88 & 0.062 & -0.10 & 0.58 & 99 & 0.058 \\
\hline Philippines & 0.02 & 0.53 & 132 & 0.046 & -0.02 & 0.53 & 128 & 0.047 \\
\hline Singapore & 0.02 & 0.55 & 637 & 0.022 & -0.03 & 0.51 & 644 & 0.020 \\
\hline S. Korea & -0.37 & 0.70 & 7 & 0.266 & -0.10 & 0.86 & 13 & 0.239 \\
\hline Taiwan & 0.19 & 0.73 & 17 & 0.177 & -0.36 & 0.62 & 20 & 0.139 \\
\hline Thailand & 0.01 & 0.55 & 410 & 0.027 & -0.04 & 0.53 & 429 & 0.026 \\
\hline \multicolumn{9}{|c|}{ Region: Latin America } \\
\hline Argentina & -0.13 & 0.61 & 47 & 0.089 & -0.07 & 0.61 & 55 & 0.082 \\
\hline Brazil & -0.04 & 0.57 & 272 & 0.034 & -0.10 & 0.53 & 279 & 0.032 \\
\hline Chile & -0.02 & 0.87 & 93 & 0.090 & 0.06 & 0.76 & 110 & 0.072 \\
\hline Mexico & 0.01 & 0.75 & 39 & 0.120 & 0.03 & 0.70 & 64 & 0.088 \\
\hline \multicolumn{9}{|c|}{ Region: Greater Middle East and Africa } \\
\hline Israel & 0.03 & 0.61 & 240 & 0.040 & -0.08 & 0.57 & 239 & 0.037 \\
\hline Pakistan & 0.02 & 0.56 & 241 & 0.036 & 0.02 & 0.51 & 254 & 0.032 \\
\hline Turkey & 0.02 & 0.58 & 127 & 0.051 & 0.02 & 0.63 & 156 & 0.050 \\
\hline South Africa & 0.02 & 0.61 & 241 & 0.039 & -0.08 & 0.56 & 260 & 0.035 \\
\hline Total & 0.03 & 0.53 & 15447 & 0.004 & -0.06 & 0.53 & 15606 & 0.004 \\
\hline
\end{tabular}

Note: This table reports the distribution of the firm-level time-series correlation between labor expenses growth and $\triangle \mathrm{DEBT}(\operatorname{Corr}(\triangle X L R, \triangle D E B T))$, and the correlation between labor share and $\triangle \mathrm{DEBT}$ $(\operatorname{Corr}(L S, \triangle D E B T)) . \Delta X L R$ and $L S$ are time $t$ variables, whereas $\triangle D E B T$ is a $t+1$ variable. For every firm, we calculate $\operatorname{Corr}(\triangle X L R, \triangle D E B T)$ and $\operatorname{Corr}(L S, \triangle D E B T)$ using its time-series observations. Then we report the mean and standard deviation of these two correlations within each country; we also report the same summary statistics for all countries in the last row "Total". The standard error is for testing whether $\operatorname{Corr}(\triangle X L R, \triangle D E B T)=0$ or $\operatorname{Corr}(L S, \triangle D E B T)=0$. 